\title{
Parental Leave, (In)formal Childcare and Long-term Child Outcomes
}

by

Natalia DANZER

Martin HALLA

Nicole SCHNEEWEIS

Martina ZWEIMÜLLER

Working Paper No. 1706

This Version: August 2020

First Version: May 2017

Johannes Kepler University of Linz Department of Economics Altenberger Strasse 69 A-4040 Linz - Auhof, Austria www.econ.jku.at 


\title{
Parental Leave, (In)formal Childcare and Long-term Child Outcomes*
}

\author{
Natalia Danzer ${ }^{\mathrm{a}, \mathrm{b}, \mathrm{c}, \mathrm{d}}$, Martin Halla ${ }^{\mathrm{d}, \mathrm{e}, \mathrm{f}, \mathrm{g}}$, Nicole Schneeweis ${ }^{\mathrm{d}, \mathrm{e}, \mathrm{f}, \mathrm{h}}$, Martina \\ Zweimüllere,f \\ ${ }^{a}$ Freie Universität Berlin, Germany \\ ${ }^{\mathrm{b}}$ ifo Institute, Munich, Germany \\ ${ }^{\mathrm{c}}$ CESifo, Munich, Germany \\ ${ }^{\mathrm{d}}$ IZA, Institute for the Study of Labor, Bonn, Germany \\ e Johannes Kepler University Linz, Austria \\ ${ }^{\mathrm{f}}$ Christian Doppler Laboratory for Aging, Health and the Labor Market, Austria \\ ${ }^{\mathrm{g}}$ Austrian Public Health Institute, Vienna \\ ${ }^{\mathrm{h}}$ CEPR, Centre for Economic Policy Research, London
}

August 14, 2020

(First version: May 22, 2017)

\begin{abstract}
We evaluate the effect of an Austrian parental leave extension from the child's first to its second birthday on long-term child outcomes. Our identification is based on a sharp birthday cutoff-based discontinuity in the eligibility for extended parental leave. Our results show that a longer parental leave duration improves on average child health outcomes, but has no effect on the child's labor market outcomes. The estimated treatment effects differ substantially according to the availability of formal childcare and the mother's counterfactual work behavior. This suggests that accounting for the counterfactual mode of care is important in the evaluation of parental leave reforms. Our analysis of treatment effect heterogeneity reveals significant gains in all outcomes for children, for whom the reform most likely induced a replacement of informal childcare with maternal care.
\end{abstract}

JEL Classification: J13, H52, J22, J12, I38.

Keywords: Parental leave, formal childcare, informal childcare, child development, child health, maternal labor supply, fertility.

\footnotetext{
${ }^{*}$ Corresponding author: Nicole Schneeweis, Johannes Kepler University Linz, Department of Economics; email: nicole.schneeweis@jku.at. For helpful discussions and comments we would like to thank Joshua Angrist, Christian Dustmann, Albrecht Glitz, Libertad Gonzalez, Timo Hener, Helmut Rainer, Anna Raute, Heather Royer, Steven Stillman, Andrea Weber, Rudolf Winter-Ebmer, Josef Zweimüller, and participants of seminars at the University of Linz, the Ski and Labor Workshop 2014 in Laax, the Annual Meeting 2014 of the Education Economics Committee of the Verein für Socialpolitik in Munich, the University of Mannheim, the Ifo Institute, the ESPE Annual Conference 2014 in Braga, the University of Innsbruck, the Austrian Institute of Economic Research (WIFO), the Centre for European Economic Research (ZEW), the University of Salzburg, the National Taiwan University, the Free University of Bozen-Bolzano, the Swedish Institute for Social Research (SOFI) at Stockholm University, the Pompeu Fabra University, the Early Childhood Inequality Workshop 2016 in Nuremberg, the Labor Economics Workshop 2016 of the Austrian Chamber of Labor, the Annual Conference of the German Economic Association 2017 in Vienna, and the Annual Conference of the European Association of Labour Economist 2017 in St. Gallen. The usual disclaimer applies. This research was funded by the Austrian Science Fund (FWF): National Research Network S103, The Austrian Center for Labor Economics and the Analysis of the Welfare State. We also gratefully acknowledge financial support from the National Foundation of Research, Technology and Development and the Leibniz Association (Germany).
} 


\section{Introduction}

There is a strong public and private debate about who should provide care to young children (Gregg and Waldfogel, 2005). This question has gained importance against the background of increasing female labor force participation and the absence of grandparents within the household. Governments in many countries have responded to these developments by offering two alternative institutions: formal childcare and parental leave (PL) policies. These two institutions promote competing models of family organization. Proponents of PL policies prefer mothers, and more recently also fathers, as the main caregivers. By contrast, advocates of formal childcare prefer children to spend time in a nursery and parents to participate in the labor market.

We evaluate the effect of an extension of paid and job-protected PL in Austria from the child's first to its second birthday on long-term child outcomes. We add to the literature in two important ways. First, based on a clean research design, we analyze a wide range of child outcomes measured in high-quality administrative data that covers the universe of children. Apart from estimating long-run labour market impacts, we extend the literature by providing first insights into long-run health effects of children. The analysis shows that, on average, the PL extension had no effects on educational and labor market outcomes, but positive effects on health. Thus, complementing the set of human capital indicators by the long-run health dimension turns out to be relevant for the evaluation of parental leave reforms on child development. Second, we demonstrate the importance of the counterfactual mode of care in PL evaluations, which the previous literature has proposed as a key explanation for heterogeneous effects across studies. We combine our as good as randomly assigned PL length with approximations for the counterfactual mode of care. The latter is driven by two factors. The first factor is the local availability of formal childcare. The second factor is the mother's counterfactual work behavior. We find strong treatment effect heterogeneity according to the availability of formal childcare and the mother's counterfactual work behavior. Positive effects are only observed for families, who most likely substituted informal care arrangements with maternal care, and not for families who relied on maternal care before and after the reform. In communities where formal childcare is available, the reform had no statistically significant effects on children. Since we cannot claim that formal care was the only counterfactual mode of care in these communities, the results are comparably harder to interpret. Even though we lack exogenous variation in access to formal childcare and data on individual child care arrangements, our careful analysis and falsification checks all support the interpretation that the effects of PL indeed depend on the type of care which is being replaced by maternal care.

In our analysis, we implicitly assess the role of maternal care and PL in promoting child development relative to non-parental - formal and informal - care arrangements. While these two institutions have thus far been evaluated in two - hardly connected - strands of the eco- 
nomics literature, we argue that a joint evaluation provides an improved understanding of the determinants of child development and long-term outcomes.

In Austria, PL has been a right for mothers since 1957. In 1990, paid and job-protected PL was extended by 12 months. Mothers of children born on June 30 or earlier were eligible for one year of PL, while mothers who gave birth on July 1 or later were entitled to take PL until the child's second birthday. Our research design combines a regression discontinuity design (RDD) with a difference-in-differences (DiD) approach. We exploit the fact that the eligibility for extended PL was based on a sharp birthday cutoff date. Thus, we compare families with children born shortly before and after the cutoff date. As the reform was only enacted around three months before the cutoff date, sorting into treatment by planning conception can be ruled out. However, as parents may postpone the date of delivery, we exclude children born five days before and after the cutoff date. Additionally, we use unaffected control cohorts to difference out potential seasonal or age effects.

The PL reform is particularly well-suited for our purposes not only because of its scale, but also because it affected virtually all working women: eligibility was extremely high and takeup rates were almost universal (Lalive and Zweimüller, 2009). By combining various sources of administrative data, we investigate how the PL extension affected children's educational, labor market, and health-related outcomes. Our data also allow us to deepen and enrich our analysis by investigating the reform's effects on other family members. We examine maternal labor supply, fertility, and family stability up to 17 years after childbirth. The analysis of these potential mediators is important to fully understand how PL policies affect child development.

Around the 1990 reform, the availability of formal childcare for under-three-year-olds (provided by nurseries) varied substantially across communities. At that time, two-thirds of the population lived in a community without a nursery. Before the reform, children of working mothers who lived in communities with nurseries had the possibility to attend a nursery, while their counterparts in communities without nurseries were in informal care, mostly provided by grandparents. We provide evidence that a sample split by the availability of formal childcare is not confounded by other community characteristics. Moreover, we combine information on pre-reform mothers labor supply with detailed data on all mothers, to approximate post-reform mother's counterfactual work behavior. A further sample split by this dimension approximates the counterfactual mode of care. This setting provides us with the opportunity to shed light on the effects of PL policies across varying counterfactual modes of childcare.

On average, we find that the reform improved child health outcomes, but had no effect on educational and labor market outcomes. These average effects mask substantial heterogeneity. While we find little variation across socioeconomic status (SES) and the child's sex, we observe strong heterogeneity with respect to the counterfactual mode of care. We find no significant effects for children in communities with nurseries, but sizeable and significantly positive effects in communities without nurseries. The latter effects are driven by mothers, who would have been working in the counterfactual situation with short PL. These mothers most likely spend 
more time with the child in the child's second year of life after the reform. We interpret these results as a positive effect of substituting informal care arrangements with maternal care. These findings suggest that care provided by mothers is superior to informal care arrangements. The prolonged PL duration also led to small changes in household income. However, we find no evidence for the relevance of this income effect.

There are several potential mechanisms, which could explain the adverse effect of informal care arrangements. First, informal childcare is typically less stable in terms of the number and type of care takers, the specific schedule, and the overall routines. There is evidence pointing to the importance of stability and parenting style based on routine and discipline for child development (Morrissey, 2009; Bono et al., 2016). Another potential channel is that children with impairments are less likely to receive (optimal) early intervention under informal care arrangements. Grandparents - the most important providers of informal care - are on average less educated than mothers and may be unable to identify the need for intervention. They might also hold more traditional and less beneficial views about child-rearing. ${ }^{1}$ Furthermore, lack of formal childcare might aggravate the parenting stress among working parents (Parkes et al., 2015), with negative implications for child development. ${ }^{2}$

The treatment effect heterogeneity by the availability of formal childcare is also observed in the analysis of family outcomes. In communities with nurseries, we find an increase in short term fertility, a reduction in maternal employment in the short run, and some positive effects on family stability in the short run. In communities without nurseries, mothers reduced the spacing between the first and the second birth somewhat and maternal full-time employment increased permanently. Yet, we provide evidence that these changing family circumstances are not the main drivers of the treatment effects on children.

Our results on potential channels expand the analyses by Lalive and Zweimüller (2009) and Lalive, Schlosser, Steinhauer and Zweimüller (2014), who investigate the short- and mediumrun effects of this reform on maternal labor supply and fertility. They show that the reform caused a substantial delay in the return to work and reduced maternal labor supply in the first years after childbirth. Accordingly, daily earnings dropped in the first three years. In the medium run, there were no significant effects on labor supply and earnings. They also document that the PL extension increased subsequent fertility among affected mothers and altered the spacing of births. We are able to show the effects on similar outcomes for up to 17 years after the reform.

Only one study has thus far investigated the effects of this PL reform in Austria on child outcomes. By using data from the OECD's Programme for International Student Assessment (PISA), Danzer and Lavy (2018) find no significant intention-to-treat effects (ITTs) of the PL extension on proficiency scores in mathematics, reading and science at age 15 . However, their

\footnotetext{
${ }^{1}$ For instance, recent epidemiological research suggests that grandparent-provided care to children under the age of 3 is related to elevated risks of childhood obesity (Black et al., 2017; Lidgate et al., 2018; An et al., 2020).

${ }^{2}$ Zhang and Managi (2020) show that a parental leave extension from 18 to 24 months to Japanese parents with childcare arrangement difficulties reduced maternal stress.
} 
subgroup analysis uncovers significantly positive effects on PISA scores for children (especially boys) of highly educated mothers. By contrast, the PL extension had zero (or negative) effects on PISA outcomes for children of less educated mothers. As the respective waves of PISA do not contain information on PL takeup, maternal employment, siblings, family status, or childcare attendance, the authors focus on ITTs and cannot explore and test potential mediators through which the reform may have affected child outcomes. Furthermore, it is unclear whether the effects on schooling outcomes persist over time and translate into long-run effects on human capital and labor market outcomes.

Our study is related to several strands of the existing literature. First, we advance the literature on PL by conducting one of the most comprehensive long-run studies of a PL reform on child outcomes and by focusing on a reform that affected leave taking in the second year after birth. ${ }^{3}$ To the best of our knowledge, we are the first study using a design-based approach to examine also the effect of PL on long-run child health outcomes. We highlight the role of the counterfactual mode of care and provide evidence on how it shapes the effect of extended PL on child outcomes. Moreover, we provide new and important insights by carefully discussing and assessing potential mediators through which the reform might have affected child outcomes.

Design-based papers have exploited unanticipated changes in paid PL to evaluate the importance of such leave and early maternal employment for child development (see the overview in Table A.5). The large majority of these studies assess the introduction or extension of paid maternity and parental leave in the first year of the child's life. The evaluated reforms extended or introduced paid and job-protected PL between 2 weeks (Norway 1987-1992, Dahl et al. (2016)) to 4 months (Germany 1979, 1986, Dustmann and Schönberg (2012), and Norway 1977, Carneiro et al. (2015)). These papers yield important insights for the policy debate in countries, which grant no or only relatively short national paid parental leaves. ${ }^{4}$ The dominant finding of these studies is that PL in the first year has no effect on child development captured by educational and labor market outcomes (see Rasmussen (2010) for Denmark, Baker and Milligan (2010, 2015) for Canada, Dahl, Løken, Mogstad and Salvanes (2016) for Norway and Dustmann and Schönberg (2012) for Germany). ${ }^{5}$ Evidence on the developmental impact of paid PL in the second year is scarce. Understanding the effect of paid PL in this age period is of growing importance, since by now a third of 30 OECD countries grant paid child-related leave of more than a year (see Appendix Table A.19). Apart from Danzer and Lavy (2018) only one study examines a paid PL extension in the second year after birth. ${ }^{6}$ Liu and Skans (2010)

\footnotetext{
${ }^{3}$ See Appendix Table A.5 for an overview of the literature. A recent literature review is provided by RossinSlater (2018).

${ }^{4}$ In 2018, only 6 of 30 OECD countries granted leave of four months or less to mothers: the United States, Mexico, Switzerland, Turkey, Spain and the Netherlands (see Appendix Table A.19).

${ }^{5}$ The only exception is the study by Carneiro et al. (2015), who document significant positive effects on long-term child outcomes of the introduction of 4 months of paid PL in Norway in 1977.

${ }^{6}$ The study by Dustmann and Schönberg (2012) includes an assessment of the extension of unpaid jobprotected leave in Germany in 1992 on track choice at age 14 (keeping PL benefits constant at a maximum of 18 months). The findings indicate that the unpaid PL extension may have reduced the probability of high-track attendance). However, the reform did not only affect maternal employment in the 2nd and 3rd year, but led to
} 
find positive effects for children of highly educated mothers of a reform in Sweden in 1988 which increased paid PL from 12 to 15 months. A crucial difference of this study to our paper lies in the institutional settings. In the Swedish case, the main alternative to parental care was subsidized centre-based childcare even at very young ages. The results by Liu and Skans (2010) are thus informative about the impact of moving children from formal into parental care. Their analysis does not provide insights about how paid PL affects child outcomes when parental care replaces informal care arrangements.

Several reasons for these differences in findings across PL studies are put forward in the literature. Potential sources of variation are institutional differences in the PL systems and methodological differences across studies. Relevant institutional aspects are the timing (i.e. the child's age) and length of leave, paid vs. unpaid leave, and the level of income replacement. ${ }^{7}$ Moreover, differences in the counterfactual childcare have been proposed as a potential key driver for heterogenous effects of PL or formal childcare across studies in the literature. ${ }^{8}$ Carneiro et al. (2015) assess whether the effects of paid PL in Norway in 1977 differ by distance to grandparents, which they use as a (rough) proxy for the potential type of informal counterfactual care available to parents (grandparental care or other informal care). However, no clear pattern emerges from their analysis. Positive effects of increased maternal care are found for selected child outcomes for both types of informal counterfactual care. Walters (2015) and Kline and Walters (2016) emphasize the role of the counterfactual preschool options for the evaluation of Head Start (formal childcare). Centers that draw more children who would not have attended a pre-school otherwise, turn out to be more effective. Those children show significant increases in test scores. In our paper, we investigate whether treatment effects vary by counterfactual care arrangements - formal versus informal — during a child's second year of life.

Methodologically, studies differ with respect to the employed estimation methods and the type of the estimated treatment effect, which is partly due to data limitations. For instance, several existing studies are restricted to estimating ITTs on children, as they cannot match child with maternal information. We have detailed information on PL takeup and can estimate local average treatment effects (LATE) for most of our outcomes.

Second, we contribute to the literature on the role of parental versus non-parental childcare for child development and human capital formation. In particular, we add to the small, but growing quasi-experimental literature on the impact of different types of childcare for children below the age of three. Most of the literature on childcare focuses on children aged three and

a sizeable reduction in cumulative available income in the first 40 months with potentially detrimental effects on child outcomes.

${ }^{7}$ Another reason for different findings in the literature might be a convex relationship between parental leave and child outcomes, i.e., the positive effect on children may increase the longer the PL duration. Previous studies have assessed relatively short PL extensions, while this study evaluates a long extension on top of an already generous system.

${ }^{8}$ See, for instance, Carneiro et al. (2015); Elango et al. (2016); Gathmann and Sass (2018); Havnes and Mogstad (2011). 
above and provides mixed results. Some studies suggest that increased informal childcare (i.e., non-center-based care provided by grandparents, relatives, or child-minders) has negative effects on child outcomes compared with parental care, while formal (i.e., center-based) childcare has no adverse effects (e.g., Bernal and Keane, 2011; Datta-Gupta and Simonsen, 2010). The quasi-experimental evidence from Norway and Germany points towards the positive effects of formal childcare on child outcomes (e.g., Havnes and Mogstad, 2011; Cornelissen et al., 2018), whereas analyses in Canada and the United States come to the opposite conclusion (e.g., Baker et al., 2008; Herbst, 2013) or find only positive effects for children from particularly disadvantaged households (Fitzpatrick, 2008; Kottelenberg and Lehrer, 2017). Cash-for-care reforms that reduced maternal labor supply and enrolment in formal childcare and after-school care in Finland (Kosonen, 2014) and Norway (Drange and Rege, 2013), improved long-run educational outcomes in Norway (Bettinger et al., 2014), but had adverse effects on schooling outcomes in Finland (Hiilamo et al., 2018). Only a few studies provide evidence for children below the age of three. ${ }^{9}$ Gathmann and Sass (2018) show that boys benefit in the short-run from a 'cash-for-care' policy reform that increased home care at the expense of informal care. While Felfe and Lalive (2018) and Drange and Havnes (2019) find positive effects for early centerbased care on child development, Fort et al. (forthcoming) report negative effects, particularly for girls. Again, differences in the counterfactual mode of care and quality of formal childcare might explain the conflicting results, making it difficult to draw general conclusions from the existing evidence (Elango et al., 2016). Better knowledge and more evidence for the impact on the very young are urgently needed, as maternal labor force participation is rising and as about one-third of under-three-year-olds in OECD countries attend formal childcare. ${ }^{10}$ Meanwhile, in many countries, a substantial share of mothers of children below the age of three (have to) rely exclusively on informal childcare arrangements if they want or have to work. This becomes evident when comparing labor force participation rates of mothers with children below the age of three and childcare enrolment rates of children of that age group: the latter are typically much lower than the former implying that many children are in informal care arrangements in Europe and in the United States (see Appendix Table A.20).

Third, we show that PL policies and non-parental childcare are important aspects of the early childhood environment, thereby contributing to the literature that emphasizes the importance of this environment for the production of human capital (Cunha et al., 2006). Indeed, our findings add to the dynamic ongoing policy debate (Elango et al., 2016; Rossin-Slater, 2018).

\footnotetext{
${ }^{9}$ We focus here on the evidence from universal childcare programs in developed countries. Preschool and childcare programs in developing countries are often targeted at the low-income population and provide not only day care but often also include nutritional programs (see, for instance, Noboa-Hidalgo and Urzùa, 2012; Behrman et al., 2004). Also see Elango et al. (2016) for a recent summary of the evidence on universal and targeted programs in developed countries.

${ }^{10}$ Enrolment rates vary between 3.1 and 67 percent (Slovak Republic and Denmark, respectively). For instance, in Norway, the enrolment rate of under-three-year-olds has increased from 22 to 54.3 percent between 1995 and 2013. Source: OECD Family Database.
} 
Countries invest heavily into PL benefits and formal childcare. ${ }^{11}$ By comparison, total familyrelated public expenditure comprised on average 2.24 percent of GDP, while expenditure related to early childhood education and care amounted to 0.71 percent. ${ }^{12}$ Given the increasing shares of working mothers and under-three-year-olds enrolled in formal day-care centers, our analysis therefore provides unique and timely insights into the interplay of maternal employment, PL policies, and non-parental childcare.

The remainder of the paper is organized as follows. Section 2 provides details on the Austrian PL reform and other relevant aspects of the institutional setting. Section 3 introduces our data. Section 4 presents our research design. We define our treatment, assignment, and outcome variables, present our estimation strategy, and discuss the identifying assumptions in this section. Section 5 presents our results. First, we show the effects of the PL reform on child outcomes in general and with regard to the counterfactual mode of care. We further discuss the importance of the availability of a nursery relative to other community characteristics. We then present evidence on various potential mediators such as fertility behavior, maternal labor supply, and family stability and show that these are not important drivers of the treatment effects on children. Section 6 concludes.

\section{Institutional background}

In this section, we describe the PL system before and after the 1990 reform. To enhance the understanding of the Austrian institutional background, we also provide information on female labor force participation, the availability and characteristics of formal childcare, and the use of informal care.

\subsection{Austrian PL system and the 1990 reform}

Before the reform, mothers were eligible for PL up to the child's first birthday allowing them to enjoy job protection and receive a flat-rate transfer. The reform extended the PL entitlement by 12 months. In particular, all eligible mothers giving birth on or after July 1, 1990 became entitled to paid and job-protected PL up to the child's second birthday.

The eligibility criteria for PL and associated transfer payments as well as the maternity leave regulations remained unaffected by the reform. Maternity leave, which precedes PL, mandates a compulsory leave period of eight weeks before and after delivery for all working mothers. This period is extended in the case of medical complications, a multiple birth, or a Caesarean section. During maternity leave, mothers receive a transfer payment that amounts to

\footnotetext{
${ }^{11}$ Among OECD countries, average public spending on maternity and PL cash benefits was 0.38 percent of national GDP in 2011. Among countries with positive spending the share varies between 0.02 percent (Turkey) and 1.38 percent (Estonia) in 2011. Source: OECD Social Expenditure Database.

${ }^{12}$ Total family-related expenditure in 2011 ranges from 0.02 to 4.05 percent of GDP (for Turkey and Denmark, respectively); expenditure on early childhood education and care ranges from 0 (only Turkey) to 2.01 (Denmark) percent. Source: OECD Social Expenditure Database.
} 
100 percent of their average net earnings of the preceding 13 weeks (Wochengeld). To become eligible for PL, mothers needed to be in employment (subject to compulsory social insurance contributions) for at least 52 weeks during the two years preceding the first birth. For young mothers (below 25 years), 20 weeks of equivalent employment during the last 52 weeks were sufficient. During the PL period, eligible women received a monthly transfer payment of $€ 352$ (in 2015 values). ${ }^{13}$ This corresponded to about 40 percent of net median female earnings. As a side effect, the 1990 PL extension also prolonged the automatic renewal period during which mothers were allowed to transition from one PL spell to the next without fulfilling the work criteria. ${ }^{14}$ Lalive and Zweimüller (2009) show that this change affected the timing and spacing of second births. Since we focus on first-born children, this aspect of the reform affects our analysis only indirectly.

Several features of the reform make it particularly suitable for our analysis, as they allow us to identify causal effects. First, the reform was implemented with a clear cutoff date and there were no transition rules. Hence, entitlement to the extended leave period was strictly limited to mothers giving birth on or after the cutoff date. Second, the PL extension was announced and implemented at relatively short notice. It passed the Austrian parliament only in April 1990 and was first publicly discussed in mid-November 1989, about 7.5 months before it came into effect (Lalive and Zweimüller, 2009). This precluded parents from adjusting the timing of conception to exploit the more generous PL regime. Indeed, we find no evidence that parents postponed their delivery date. Third, the reform affected the vast majority of mothers, since about 90 percent of all first-time mothers were eligible and PL takeup among eligible mothers was about 97 percent. Fourth, the reform increased the average PL duration substantially.

\subsection{Female labor force participation}

In 1990, about 64 percent of all Austrian women between the ages of 25 and 54 participated in the labor market, a rate lower than those in Scandinavian and Anglo-Saxon countries, comparable to that in Germany, and well above those in Southern Europe. ${ }^{15}$ For the population of women without children (between the ages of 25 and 40) participation rates were substantially higher, namely 88.3 percent. ${ }^{16}$ Hence, the vast majority of these women should have been

\footnotetext{
${ }^{13}$ Non-married mothers who did not live in the same household with the child's father and who did not receive sufficient child support from him, and married mothers whose husbands earned no or low income received about 50 percent higher assistance.

${ }^{14}$ The automatic renewal period elapsed 3.5 months after the expiration of the maximum PL. To benefit from this PL renewal, pre-reform (post-reform) mothers had to give birth to another child within 15.5 (27.5) months of the previous birth.

${ }^{15}$ According to estimates of the International Labour Office, the overall female labor force participation rates in the year 1990 were 90.9 in Sweden, 87.7 in Denmark, 79.1 in Norway, 74.0 in the United States (US), 73.0 in the United Kingdom (UK), 63.3 in Germany, 63.8 in Austria, 52.4 in Italy, and 51.8 in Greece. Over time, the Austrian overall female labor force participation rate has increased. Since the early 2000s the Austrian rate has been above 80. Austria overtook the US and the UK, and is approaching to Scandinavian levels. Source: ILOSTAT Database (accessed on September 20, 2016).

${ }^{16}$ Own calculations based on Austrian Census data from the year 1991. The corresponding participation rates for women with one and two children were 78.0 and 57.8 percent, respectively.
} 
eligible for PL and thus affected by the reform. According to data taken from the Austrian Birth Register, about 90 percent of women having their first birth in 1990 were employed (i.e., on maternity leave) at the time of birth. This figure matches very well with the share of eligible mothers that we calculate from our administrative data (the Austrian Social Security Database, $A S S D$ ) based on precise information on prior employment.

\subsection{Formal and informal childcare}

The Austrian system of formal childcare distinguishes between facilities for children below the age of three (nurseries, Kinderkrippe/Krabbelstube) and for those aged three to six (kindergarten or preschool, Kindergarten). While the vast majority of communities have offered a kindergarten since the 1980s, the local availability of nurseries has been traditionally much lower. In 1990, about 2 percent of communities had nurseries. The existing nurseries were predominantly in more densely populated areas. Therefore, the share of the covered population (around 33 percent) was substantially larger than the share of communities (see Table 1). This fact created a regional dispersion in the local availability of nurseries that we exploit in our analysis of treatment effect heterogeneity. Importantly, the supply of nurseries was stable in the years around the reform.

\section{[Table 1]}

The upper panel of Figure 1 plots the raw enrolment rates of children below one year, between the ages of one and two and between the ages of two and three for communities with nurseries. We calculate these raw rates by using data on the number of enrolled children by age and community and the number of children in the respective birth cohort and community. ${ }^{17}$ These raw rates cannot be directly applied to our estimation sample, since we cannot distinguish between children's parity, country of birth, and their mothers' employment status. In our estimation sample, we include only first-born children born in Austria whose mothers were eligible for PL. We expect substantially higher enrolment rates for this group.

Between 1988 and 1990, the raw enrolment rate was below 0.5 percent for children under one year, around 8 percent for one-year-old children, and around 17 percent for two-year-old children. In the two years after the PL extension in 1990, the enrolment rate of one-year-olds decreased substantially, while it remained constant for the other two groups. In 1992, the year in which the figure for one-year-olds represents the first complete post-reform cohort (born between January and December 1991), the enrolment rate dropped by half. This finding is

\footnotetext{
${ }^{17}$ Own calculations based on official statistics on children in center-based care (Statistics Austria, Kindertagesheimstatistik, Statcube, retrieved on November 17, 2016) and the Austrian Birth Register.
} 
in line with the notion that the PL extension induced a substitution of formal childcare with maternal care for one-year-olds. ${ }^{18}$

[Figure 1]

Since only the children of parents who both work (typically at least 20 hours per week) were eligible for formal childcare, enrolment rates for the population at risk were higher than the raw rates calculated above. We approximate the enrolment rates of (full-time) employed mothers by using only children of (full-time) employed mothers as a denominator. More specifically, we use the (full-time) employment rate of pre-reform mothers in the second year of the child's life to adjust the denominator of the raw rate. Only 35 percent of these mothers were employed (21 percent were employed full-time) even in the absence of the PL entitlement. This leads to adjusted enrolment rates of around 22 percent and 35 percent between 1988 and 1990 for children of employed and full-time employed mothers, respectively (see lower panel of Figure 1). ${ }^{19}$ Thus, the PL reform induced a replacement of formal childcare with maternal care for a substantially higher share of children than suggested by the raw enrolment rates.

The vast majority of nurseries are public and typically operated by the respective municipal government. In 1990, about 70 percent of enrolled children were in a public nursery. Private nurseries operate under the same regulatory environment, receive substantial subsidies, and have to fulfill pre-defined quality standards. The operators of private nurseries are non-profit associations (17.6 percent of children), private persons (11.0 percent of children), and other entities (1.4 percent). The effective average group size in nurseries was about 15 children in 1990, and there were about two educators per group. On average, 1.5 of these graduated from a college for nursery education (ISCED level 4B degree). ${ }^{20}$ Information about fees for formal childcare institutions in the early 1990s is sparse. Own estimates based on the Austrian Microcensus from 1995 reveal that the average monthly expenditure on formal childcare for two-year-olds including lunch were about $€ 220$ (in 2015 prices). These costs correspond to about 10 to 17 percent of the average monthly earnings of women at that time. ${ }^{21}$

The availability and structure of informal childcare is comparably hard to describe, since we have to rely on survey data. The most recent pre-reform survey data including detailed information on informal childcare are from 1983. In this year, the Austrian Microcensus included a special supplement on childcare. According to these data, about 63 percent of children

\footnotetext{
${ }^{18}$ Note that the increase in the raw enrolment rate between 1993 and 1994 is partly due to a change in the definition of the age groups. While up until 1993 the age definition is based on calendar years (January 1 to December 31), from 1994 onwards school years were applied (September 1 to August 31). Thus, the latter consists of children who are older by 3 months on average.

${ }^{19}$ Since the numerator contains children of all working mothers, the estimated enrolment rates for children of full-time employed mothers represent upper bounds.

${ }^{20}$ Own calculations based on official statistics on children in center-based care (Statistics Austria, Tagesheimstatistik, Statcube, retrieved September 9, 2016).

${ }^{21}$ According to our estimates from the Austrian Microcensus 1995, average monthly earnings of employed women in childbearing age (aged 20 to 45 ) were about $€ 1,304$, when considering only women working 35 hours or more, this average wage was about $€ 1,461$.
} 
from working mothers were in any type of informal care arrangement during their second year of life on a weekly or daily basis. Among informal care arrangements, the most common care providers were grandparents (89 percent) followed by other relatives (10 percent). Nannies (or other forms of paid help) were uncommon at that time.

To summarize, the childcare options of working mothers were regionally dispersed. Hence, for children born in communities without nurseries, the PL extension in 1990 implied a shift from informal childcare (mostly by grandparents) to maternal care in the second year of life. For children born in communities with nurseries, the 1990 reform resulted in a substitution of formal and informal childcare with maternal care. As it turns out, these different counterfactual modes of non-parental childcare determine the effects of the PL extension on child outcomes.

\section{Data}

We construct our main data set by combining various administrative data sources. In our main data set, we observe the universe of births with detailed information on families' SES. Most importantly, we can follow the mother and child over time along different aspects of life. The $A S S D$ provides information on the mother's eligibility for PL, her actual takeup, her return to work behavior, the child's labor market behavior, and any other event relevant for pension claims such as periods of military service. ${ }^{22}$ The Austrian Birth Register enables us to closely track subsequent fertility behavior. The Austrian Marriage Register and Austrian Divorce Register document any change in marital status. Finally, the database provided by the Ministry of Labour, Social Affairs and Consumer Protection includes information on current formal education (school or college attendance) and disability status. We use these data to generate our outcome variables, our treatment and assignment variables, and a comprehensive set of covariates. We define a number of children's medium- and long-term labor market and health outcomes. At the family level, our outcome variables include measures of subsequent fertility, maternal labor supply, and marital status. Starting from the universe of children born in Austria, we restrict our analysis to first-born singleton children of mothers aged between 15 and 45 years at the time of birth and eligible for PL. ${ }^{23}$

Unfortunately, the ASSD comprises only very limited information on individuals' education. Hence, to assess the reform's impact more comprehensively, we use two complementary data sources: the PISA data from 2003 and 2006 and data from the Educational Register of the city of Linz (EducReg). However, peculiarities of these data do not allow us to implement the same elaborate estimation strategy as in the case of our main data set. Due to this limitation, we

\footnotetext{
${ }^{22}$ The ASSD includes administrative records to verify pension claims and is structured as a matched employeremployee data set. We observe for each individual on a daily basis where she is employed, along with her occupation, experience, and tenure. Information on earnings is provided per year and per employer. The limitations of the data are top-coded wages and the lack of information on (contracted) working hours (Zweimüller et al., 2009).

${ }^{23}$ We find no difference in the share of twins or multiple births before and after the reform cutoff date.
} 
only briefly discuss these results in the paper and relegate a detailed discussion to the Appendix Section A.1, which also provides a description and discussion of the data and the estimation strategy.

\section{Research design}

We estimate the effect of the PL extension by combining an RDD with a DiD approach. In this setup, the treatment resembles a prolonged duration of paid and job-protected PL up to the child's second birthday. The assignment into treatment depends on whether a child is born in the post-reform period. To identify the treatment effect, we exploit the discontinuity in the PL duration at the reform date and compare child and other family outcomes of children born shortly before and after the reform. Additionally, we use unaffected control cohorts to difference out potential seasonal or age effects. In our regressions, we include children born in 1989 as a control cohort.

\subsection{Treatment and assignment variables}

The treatment variable is defined as the PL duration (including post-birth maternal leave). The maximum PL duration is one year before and two years after the reform. Assignment into treatment depends on whether a child is born in the post-reform period (on July 1, 1990 or later). Panel A of Figure 2 depicts the relationship between assignment and treatment for eligible mothers. It plots, by birthdate, the average PL duration measured in days (including the compulsory post-birth maternity leave period which is, on average, 56 days). In 1990, we observe a distinct jump in the average PL duration from 350 to 650 days. Hence, the reform increased the average PL duration by 300 days. By way of comparison, the average PL duration in 1989 was 349 days and has no intra-year variation at all.

\section{[Figure 2]}

Eligibility and takeup rate Panel B of Figure 2 depicts that the share of eligible mothers is about 90 percent pre- and post-reform. Panel $\mathrm{C}$ of Figure 2 refers to the takeup rate among eligible mothers. The actual takeup of PL is almost universal in both periods (around 97 percent). In both years, there is no discontinuous change in the respective share around the cutoff date.

\subsection{Outcome variables}

Children's labor market outcomes Austria has a system of early tracking. The majority of students who graduate from the low track enter the workforce at around age 16, ideally via the dual education system, or as unskilled workers. We analyze children's labor market outcomes from the age of 17 and follow them until they are 23. To capture that Austrian children 
in this age cohort are either productive in school and/or in the labor market, we define the outcome variable 'active'. Children are categorized as active if they are in education (school, apprenticeship, or university), employed, in military (or alternative civilian) service, or on maternity leave/PL. Inactive children are either unemployed, only marginally employed, disabled, on long-term sick leave, or on rehabilitation.

In particular, we define binary variables capturing children's activity status at the ages of 17 and 23. While almost 98 percent of all children are active at the age of 17 , this share drops to about 90 percent at the age of 23 . We also define a variable that captures the share of active periods between the ages of 17 and 23 (87 percent on average) and a binary variable for children active in each period during this age range. The latter variable has a mean of 0.49 . To further explore the type of activity, we define binary indicators for being in education (26 percent) and in employment (61 percent) at age 23. Finally, we check for any treatment effects on the log of wages. Table 2 summarizes these and all the other outcome variables.

\section{[ Table 2]}

Children's health outcomes We use two binary outcome variables to measure children's health. The first variable assesses the disability status up to the age of 23 . We exploit the available information on the receipt of an increased family allowance due to disability between the ages of 7 and 23. A family allowance is granted for any child until the child turns 18. An increased allowance is granted if a child has a physical or mental disability of at least 50 percent. This applies, for instance, to a child who has a developmental disorder due to an impairment in physical, learning, language, or behavior areas (e.g. learning disabilities, attention deficit hyperactivity disorder) of a certain degree. ${ }^{24}$ When a child turns 18 , a family allowance is only granted if the child is in education (up to a certain age) or the child is permanently unable to work due to disability. The latter group receives the increased allowance. The degree of the disability and the incapacity to work has to be certified by the regional medical officer. We define a binary variable non-disabled that indicates that a child has never received an increased family allowance between the ages of 7 and 23 (i.e., has never had a disability of at least 50 percent) and was never permanently unable to work. In our estimation sample, 95 percent are non-disabled.

The second health variable indicates whether male children are fit for military service. This is derived from the ASSD, which provides information on whether a man has served in the military or carried out alternative civilian service. In Austria, all male citizens are subject to compulsory military service and must enlist for examinations within a year of their 17th birthday. These examinations last for two days and show whether the individual is physically

\footnotetext{
${ }^{24}$ In the US, $14 \%$ of all children had any developmental disorder in 1997-2008. The most common categories were learning disabilities (7.7\%), attention deficit hyperactivity disorder (6.9\%), and other developmental delay $(3.7 \%)$. The least common categories were blindness $(0.1 \%)$, cerebral palsy $(0.4 \%)$, hearing loss and autism (both 0.5\%) (Boyle et al., 2011).
} 
and mentally able to serve in the military. In our sample, 78 percent of boys are fit for military service. This percentage is roughly in line with official statistics (74 percent in 2006, Statistik Austria (2008)).

Children's educational outcomes In our complementary analysis on educational outcomes, we analyze PISA test scores in the fields of mathematics, science, and reading achieved at age 15/16. Further, using the Educational Register for the city of Linz and PISA data, we check whether the child attended a high track (concluding with a university entrance exam) or a low track school in grades 8 and 9 (see Appendix Section A.1 for further details).

Mothers' outcomes We examine mothers' labor market behavior up to 17 years after the birth of their first child. This analysis is based on two variables measuring the extensive and intensive margin. The extensive margin is captured by binary indicators coded one if mothers are employed $t$ years after parity one. Since we do not observe (contracted) working hours in our data, we have to approximate full-time employment based on earnings to measure the intensive margin. We define mothers as full-time employed $t$ years after parity one if they earn a real daily wage of at least 75 percent of their average pre-birth earnings (over the two years before birth). ${ }^{25}$ Ten years after parity one, about 59 percent of mothers are employed, and about 37 percent are full-time employed.

Fertility and family stability Finally, we examine fertility and family stability up to 17 years after parity one. Fertility is measured with a binary indicator of whether the mother gave birth to a further child and as the total number of children $t$ years after parity one. 10 years after parity one, 68 percent of mothers have a further child and the average number of children is about 1.9 in our sample. To assess family stability, we check whether parents are legally married $t$ years after parity one. In our sample, about 62 percent of children were born to a married mother. Potential post-birth changes in family status comprise marriage and divorce. Ten years after parity one, about 74 percent of parents are married.

\subsection{Econometric model}

We exploit the sharp birthday cutoff-based discontinuity in the eligibility for extended PL to estimate the treatment effects on all the outcomes discussed above. While the relationship between assignment and treatment is strong, it is not fully deterministic. Hence, we set up a fuzzy $R D D$-DiD. We use assignment into treatment as an instrumental variable (IV) for the endogenous treatment variable. The design can be translated into the following two-stage least squares (2SLS) setup:

$$
P L_{i}=\alpha_{0}+\alpha_{1} T_{i}+\alpha_{2} A_{i}+\alpha_{3} f\left(\text { run }_{i}\right)+\alpha_{4} f\left(\text { run }_{i}\right) \cdot A_{i}+\mathbf{x}_{\mathbf{i}, \mathbf{t}=\mathbf{0}} \gamma^{\prime}+\mu_{c}+\eta_{i}
$$

\footnotetext{
${ }^{25}$ Note that our sample consists of mothers who gave birth to their first child. Most likely these mothers worked full-time before giving birth. Only 9.8 percent of women aged between 15 and 44 who were employed in 1990 and had no children worked below 35 hours per week (Statistik Austria, 1990). We are fully aware that not all changes in wages are due to changes in working hours but also due to job mobility, promotions and demotions.
} 


$$
O_{i}=\beta_{0}+\beta_{1} \hat{P L_{i}}+\beta_{2} A_{i}+\beta_{3} f\left(\text { run }_{i}\right)+\beta_{4} f\left(\text { run }_{i}\right) \cdot A_{i}+\mathbf{x}_{\mathbf{i}, \mathbf{t}=\mathbf{0}} \delta^{\prime}+\nu_{c}+\epsilon_{i}
$$

In the first-stage equation (1), the dependent variable is $P L_{i}$, the actual PL duration measured in years. The assignment variable $T_{i}$ is coded one if a child is born in the post-reform period (after June 1990). $A_{i}$ is a binary indicator that is coded one if a child belongs to the 1990 birth cohort or the control cohort, and was born after June. $\mu_{c}$ is a birth cohort specific effect. The running variable run $_{i}$ is the child's birthdate centered at the cutoff (July 1). We choose a linear specification of $f\left(\right.$ run $\left._{i}\right)$ in our baseline model, and interact $f\left(\right.$ run $\left._{i}\right)$ with $A_{i}$ to allow for separate trends before and after the cutoff. The vector of pre-determined covariates $\mathbf{x}_{\mathbf{i}, \mathbf{t}=\mathbf{0}}$ comprises information on maternal age at birth (15-20 years, 21-25 years, ... 35-45 years), maternal SES, ${ }^{26}$ maternal migration status, the sex of the child, and whether the child was born pre-term. $\eta_{i}$ is a stochastic error term. In the second-stage equation (2), we regress the respective outcome variable $O_{i}$ on the predicted PL duration from the first stage $\hat{P L}_{i}$. We use triangular weights and cluster our standard errors at the community-level. In our baseline specification we use a bandwidth of 30 days on either side of the cutoff (i. e., children born in June and July). To account for unobserved characteristics that follow a seasonal pattern between children born in June and July, we include children born in 1990 and the pre-refrom year 1989. ${ }^{27}$ This $\mathrm{DiD}$ component of our approach assumes that unobserved seasonality is constant across 1989 and 1990.

The coefficient of interest is $\hat{\beta}_{1}$. It can be interpreted as Local Average Treatment Effect (LATE), that is, the causal effect of an additional year of PL by being assigned to the new regulations. Three conditions need to hold for $\hat{\beta}_{1}$ to be informative about the causal effect of an additional year of PL for assigned families. First, assignment to the increased PL duration $T_{i}$ must predict actual takeup $P L_{i}$. Second, families must not precisely manipulate their child's dates of birth around the eligibility cutoff. Third, assignment must not be correlated with any outcome-determining factor. The first condition is testable. We have already shown the distinctive jump in the takeup rate at the cutoff (see panel A of Figure 2). This condition also holds in our regression framework, where we obtain a $\hat{\beta}_{1}$ of 0.823 , implying that assignment increases the average PL duration by 0.823 years or 300 days. The estimated coefficient is highly statistically significant with an F-statistic of about 5,062. This coefficient is stable across subsamples. ${ }^{28}$

The inability to precisely manipulate assignment into treatment is the key identifying assumption behind any RDD. Public discussion about the potential reform of the PL system

\footnotetext{
${ }^{26}$ We form two groups based on education and pre-birth earnings. We classify mothers as low SES all mothers who completed compulsory schooling or who completed apprenticeship training or intermediate vocational school and have below median pre-birth earnings. High SES mothers are all mothers with at least higher school or who completed apprenticeship training or intermediate vocational school and above median pre-birth earnings.

${ }^{27}$ There is some evidence for the US (Buckles and Hungerman, 2013) that children born at different times of the year are born to mothers with significantly different characteristics. There is evidence from Austria (Schneeweis and Zweimüller, 2014) that the birth month is important in determining education outcomes due to relative age effects in schools.

${ }^{28}$ The largest difference is observed between mothers with low and high SES, for whom we obtain coefficients of 0.844 and 0.799 , respectively.
} 
started in November 1989 (Lalive and Zweimüller, 2009). By June 27, 1990, the Austrian government had enacted the law. This timing rules out that parents adjusted their conception behavior. The only way for parents to manipulate the birthdate was to prolong the pregnancy. Mothers with a due date sufficiently close to July 1, 1990 could try to postpone birth by a couple of days. Figure 3 shows that the average number of births per day does not vary around the cutoff date. ${ }^{29}$ Thus, there is no evidence of manipulations of the birthdate. Still, to be on the safe side, we exclude births five days before or after the cutoff date. ${ }^{30}$ This so-called "donut" sample should be free of any sorting. Depending on the outcome under consideration, our sample has around 8,500 observations (see Table 2 for more details).

\section{[Figure 3]}

Whether assignment is correlated with any outcome-determining factor is not fully testable. Figure 4 shows RD plots of all covariates and other predetermined variables for children born in June and July 1990. These plots reflect only the RDD component of our analysis, and show small discontinuities in some characteristics (for instance, mother's age). Since we cannot assess statistical significance from these graphs, we use our sample of children born in 1989 and 1990 to test for differences in the means of the covariates and other predetermined variables between pre-reform and post-reform families. ${ }^{31}$ Table 3 shows no quantitatively important differences. Few are statistically significant, but there is no evidence of a systematic pattern. We further mimic our estimation model and estimate 2SLS regressions with predetermined characteristics as outcome variables, similar to equations (1) and (2), but not including the vector $\mathbf{x}_{\mathbf{i}, \mathbf{t}=\mathbf{0}}$. This test accounts for both, the RDD and the DiD component of our analysis. Almost all coefficients are statistically not significant. Results are presented in Appendix Table A.6. Based on this evidence, we have no reason to expect a correlation between assignment and any unobserved outcome-determining factor (included in the error term $\epsilon_{i}$ ).

[Figure 4 and Table 3]

\section{Results}

We present our estimation results in three steps. First, we assess the average causal effects of the PL extension on children's medium- and long-term educational, labor market, and health outcomes. We pay attention to the robustness of these results in several sensitivity tests focusing

\footnotetext{
${ }^{29}$ More formally, we use a manipulation test for discrete running variables as suggested by Frandsen (2017) and obtain p-values of 0.53 for 1990 and 0.97 for 1989 . We choose $k=0$ implying the highest possible power to detect deviations from linearity in the probability mass function of the running variable.

${ }^{30}$ One of the first studies to demonstrate marginal timing of births due to financial incentives is Dickert-Conlin and Chandra (1999) for the US.

${ }^{31}$ Results are very similar if we test for differences between children born in June and July 1990 only.
} 
on the regression specification and sample definition. Second, we go beyond the analysis of average effects and provide an analysis of treatment effect heterogeneity. We focus here on the counterfactual mode of care and the relevance of altered maternal time inputs versus income resources during the child's second year of life. Third, we examine the treatment effects on family size, maternal labor supply, and family stability up to 17 years after birth. Any significant behavioral response along these dimensions may constitute important causal channels for the effects on children. While we find evidence for behavioral responses, we show that these are not important drivers of the treatment effects on children.

\subsection{Average effects on child outcomes}

Table 4 presents the estimation results for the labor market and health outcomes of children for the full sample. ${ }^{32}$ Column (1) presents our baseline specification, where we use a bandwidth of 30 days, control for linear trends on either side of the discontinuity, and include the vector of pre-deterimined covariates $\mathbf{x}_{\mathbf{i}, \mathbf{t}=\mathbf{0}}$ (i. e., maternal age at birth, maternal SES, maternal migration status, the child's sex, and whether the child was born pre-term).

\section{[Table 4]}

With the exception of a marginally significant positive effect on being active (age 17-23), we do not observe any significant effect of the PL extension on labor market outcomes. In contrast, there is a clear positive effect on health-related outcomes. Children who were exposed to extended PL are more likely to be non-disabled (plus 2.5 percentage points) and treated boys are more likely to be fit for military service (plus 9.9 percentage points). Since the definition of disability includes conditions such as learning disabilities or attention deficit hyperactivity disorder, the positive effect of extended PL may be driven by a higher likelihood of (appropriate) early intervention. US studies provide evidence that the early identification of impairment can improve adult health outcomes (Campbell et al., 2014).

Robustness checks The remaining columns of Table 4 show results for different robustness checks. In column (2), we omit the vector of pre-deterimined covariates. Next, we extend the set of covariates as compared to our baseline specification. In column (3), we include a large set of additional pre-determined covariates comprising information on mother's province of residence, marital status, religious denomination, educational attainment, occupation, wage, and whether the child had low birth weight. In column (4), we add a rich set of community-level covariates (population size, population density, share of catholics, share of votes for conservative parties, share of married, share of population aged 0-5 and 0-15, female employment rate, female fulltime employment rate, availability of a higher secondary school and number of classes in higher secondary schools). The exclusion and inclusion of covariates has virtually no impact on our

\footnotetext{
${ }^{32}$ Unconditional RD plots for five outcomes are presented in Appendix Figure A.1.
} 
estimates. This shows that our assignment variable is orthogonal to all covariates and suggests that assignment is indeed as good as random. The same holds for the specification summarized in column (5), where we use quadratic trends in the running variable. In columns (6) to (8), we check the sensitivity with respect to the sample used in the analysis. First, we drop all foreign-born mothers (about 6 percent of the sample). Second, we include children born $+/-5$ days around the cutoff date. Third, we increase the bandwidth to 61 days, i. e., we also include children born in May and August in our sample. Again, our estimates are quite robust to these modifications.

Educational outcomes Our complementary analysis on educational outcomes does not reveal any significant effects of the PL in the full sample (see Appendix Section A.1 for detailed results). The ITT estimates suggest that, on average, the PL extension did neither significantly affect PISA test scores nor the likelihood of high track attendance in secondary school.

Overall, the results on the average effects of the PL extension on child outcomes indicate zero or slightly positive effects on labor market outcomes, and positive effects on health status in early adulthood.

\subsection{Heterogeneities by socioeconomic status and the child's sex}

The effects of PL might depend on the socioeconomic characteristics of the parents. The direction of this potential heterogeneity is unclear. On the one hand, PL might be more beneficial for children of families with high SES. An increase in the time with a highly educated mother might further child development to a greater extent as compared to a mother with lower education. On the other hand, families with high SES are likely to have more and better resources for child rearing and an additional intervention may have a lower marginal return as compared to families with lower SES. The previous literature with respect to such heterogenous effects is ambiguous. Liu and Skans (2010) and Danzer and Lavy (2018) find positive effects of PL only for mothers with high education. Carneiro et al. (2015) find positive effects on average, with somewhat stronger effects for mothers with high education when considering earnings at age 30, but somewhat stronger effects for mothers with low education when educational outcomes of children are considered. Baker and Milligan (2015) and Rasmussen (2010) do not find any heterogeneities with respect to SES (see Appendix Table A.5).

We examine potential heterogenous effects in Appendix Table A.7. We find positive effects on some labor market and health outcomes for low SES mothers, and marginally significant positive effect on being active (age 17) for high SES mothers. However, none of the estimated coefficients differ significantly by SES. We also investigate wether the effects differ by the sex of the child. We find some positive effects at age 17 for boys and some positive health effects for girls. Again, these coefficients do not differ significantly from each other. Overall, our findings do not reveal a systematic pattern with respect to SES of the mother or sex of the child. ${ }^{33}$

\footnotetext{
${ }^{33}$ Since parental SES might play a different role in communities with and without formal childcare, we reexamine this issue below.
} 


\subsection{Accounting for the counterfactual mode of care}

Our IV estimation strategy yields a LATE for an additional year of PL for compliers relative to their own counterfactual care choices. We assume that during PL, childcare is largely provided by the mother and not by other formal or informal caregivers. This LATE is a weighted average of the LATEs for three subpopulations: (i) the LATE for children who switch from informal care to maternal care, (ii) the LATE for children who switch from formal care to maternal care, and (iii) the LATE for children who do not experience a change in the mode of care; since their mothers provide maternal care in the second year of the child's life independent of the PL entitlement. The latter children experience only an increase in family income (see Section 5.3.2). Given the evidence from the childcare literature, we suppose that the counterfactual mode of care is one of the most important sources of heterogeneity in the effect of extended PL on child outcomes.

While we cannot observe the counterfactual care situation, we pursue the following empirical strategy striving to distinguish between the three different counterfactual scenarios. In a first step, we focus on the role of non-parental childcare and exploit the regional variation in the availability of formal childcare for under three-year-olds. In communities without nurseries, the counterfactual non-parental childcare is unambiguously defined; working parents have to rely exclusively on informal childcare arrangements (mostly grandparents). In communities with nurseries, the counterfactual non-parental childcare could be formal childcare, informal care arrangements, or a combination of both. We presuppose that a considerable proportion of working first-time mothers would have relied on formal care arrangements during their child's second year of life in the absence of the reform. However, we cannot claim that it was the only counterfactual mode of care for all mothers. To assess the relevance of these differential counterfactual modes of care, we compare treatment effects across communities with and without nurseries by splitting our sample along this dimension.

In a second step, we additionally account for the counterfactual maternal labor supply in the second year after child birth. This allows us to distinguish between mothers who either would have or would not have worked in the second year in the absence of the reform. For the first group, the PL extension implied a reduction in labor supply, an increase in time at home and a partly compensated loss in earned income. For the second group, the PL extension basically implied a windfall profit in the form of a prolonged period of benefit receipt (as well as an extended job protection). This heterogeneity analysis should thus be informative about whether the PL reform affected children via increased maternal time investments and/or through increased income in the second year of life. To this end, we predict maternal labor supply in the second year after child birth and additionally split our sample based on whether the mother would have been more or less likely to work in the second year in the absence of the reform. The details of this procedure are described further below. It turns out that the 
distinction by counterfactual childcare arrangements and mothers' counterfactual work behavior unveils an important source of heterogeneity.

\subsubsection{Availability of formal or informal childcare}

While the heterogeneity analysis by counterfactual mode of childcare provides potentially very important insights, the availability of a nursery in a community is supposably not exogenous to maternal (and child) outcomes. In other words, mothers (and families) living in communities with or without nurseries presumably differ in many respects which may influence how extended PL affects children - apart from the locally prevailing counterfactual mode of care.

Descriptive statistics summarized in Table 5 illustrate that communities with and without nurseries differ along many dimensions. Importantly, average maternal characteristics tend to be better in communities with nurseries than in those without. Mothers giving birth in communities with access to formal care tend to be older, are more likely to have a high SES, are more likely to be married at the time of giving birth, have a higher educational attainment, a higher pre-birth daily wage and are more likely to be white-collar workers or civil servants. Communities with nurseries are more urban, are less conservative, have fewer children, a higher female employment rate and more supply of higher secondary schools. Thus, mothers living in communities with nurseries seem to be positively selected. In contrast, child health outcomes at birth are very similar across both types of communities.

\section{[Table 5]}

Table 6 presents treatment effects on labor market and health outcomes for children whose mothers lived in communities with and without nurseries, respectively, based on fully interacted regression models. ${ }^{34}$ For both types of outcomes, we find differences across communities: In communities with nurseries, the point estimates are mostly negative and not significant at conventional levels. On the contrary, in communities without nurseries, we find positive significant effects. This pattern is at first surprising given the less beneficial maternal socioeconomic characteristics in latter communities.

\section{[Table 6]}

In communities, where working parents can solely rely on informal care arrangements one more year of PL increases the likelihood that the child is active at age 17 by 1.6 percentage points, and for the whole period (age 17-23) by 3.1 percentage points. These estimates correspond to 1.6 and 3.6 percent of the overall sample means. At age 17, our activity measure is driven by education. Treated children in communities without a nursery are more likely to attend a school

\footnotetext{
${ }^{34}$ Unconditional RD plots for five outcomes are presented in Appendix Figures A.2 and A.3.
} 
or apprenticeship training. We do not find a statistically significant effect on being active at age 23, neither for the overall measure, nor for specific kinds of activities (e.g., education and employment) and wages (conditional on employment). At this age, it is unclear whether being in education or being employed is a better human capital outcome. Being in education would be a positive outcome if the child attends university, but would be a sign of poor achievement if the child is still in school or attends apprenticeship training. Being employed at that age would be a positive outcome for children who would be inactive, still in school, or attending apprenticeship training in the counterfactual situation; on the contrary, it would be a negative outcome for children who would attend university in the counterfactual situation. Similarly, the wage results are also difficult to interpret, since we assess wages only for the selected group of employed individuals. Because of these shortcomings, we focus on our activity measures henceforth. Being active as opposed to inactive can unambiguously be interpreted as a positive outcome.

Regarding health outcomes, our analysis shows that the average positive effects are driven by children born in communities without nurseries and amount to 3.8 percentage points and 12.3 percentage points for the outcomes non-disabled and fit for military, respectively. These effects are sizeable and corresponds to 4 and 15.7 percent of the sample means.

Robustness checks As before, we conduct several robustness checks to test the sensitivity of our findings. Lacking exogenous variation in the access to formal versus informal childcare across communities, one important aim of these sensitivity tests is to account and control for as many potential confounders in the regressions as possible. Reassuringly, the results in Table 7 show that our baseline estimates are very robust to these tests.

\section{[ Table 7]}

In particular, the positive effects of the PL extension on labor market and health outcomes of children born in communities without nurseries hold when excluding the vector of baseline covariates (column 2). The results are also robust to the inclusion of additional pre-determined characteristics (column 3), as well as a rich set of community-level characteristics (column 4). Likewise, using quadratic trends in the running variable (column 5) and excluding children with foreign-born mothers (column 6) does not affect the results. Figure 5 summarizes our baseline estimates for different bandwidths. The point estimates for communities without nurseries are not very sensitive to the choice of bandwidth, but as expected, the results are less precise for smaller bandwidths. Appendix Figure A.4 presents the sensitivity of our baseline estimates to observations near the discontinuity. Our baseline estimation sample excludes children born within \pm 5 days around the discontinuity. We vary the window length by successively removing children born within $1,2, \ldots, 10$ days around the discontinuity. The first bar shows estimates based on a sample that includes all observations. We find that our results are not sensitive to observations near the discontinuity. 
[Figure 5]

Educational outcomes The heterogeneity analysis by availability of nursery yields similarly striking differences in educational outcomes. The results suggest that the PL reform significantly improved the educational outcomes in communities without nurseries, but had zero to negative effects on educational performance in communities with nurseries (see Appendix Section A.1). However, since the educational data contain only very rough proxies for the availability of a nursery at the time of birth, these results have to be interpreted with caution.

Overall, our results show that the average treatment effects mask substantial heterogeneity. The results suggest that the local availability of childcare determines how PL shapes child outcomes and that the counterfactual mode of care plays an important role. The positive treatment effects in communities where formal childcare is not available and working mothers can only rely on informal care arrangements suggest that maternal care is superior to informal care. In communities where childcare is available, the reform had no statistically significant effects on children. Since we cannot claim that formal care was the only counterfactual mode of care in these communities, the results are comparably harder to interpret. Although we observe evidence that enrolment rates have dropped after the reform (see Figure 1), indicating that a certain share of working mothers has replaced formal care with maternal care, we cannot preclude that some mothers have replaced informal care with maternal care. In sum, the results for communities without nurseries have to interpreted with caution; thus, we cannot claim that formal care and maternal care lead to comparable child outcomes.

Maternal SES revisited As we have shown in Table 5, communities with and without nurseries do not only differ in the availability of formal childcare, but also along other dimensions. Mothers in communities without nurseries tend to have a lower SES, lower education and wages. Since we have shown above that the average treatment effects do not differ by maternal SES, it is unlikely, that the differences in socioeconomic characteristics of mothers in communities with and without nurseries drive our results. Appendix Table A.8 provides results for low and high SES mothers in both types of communities. Irrespective of maternal SES, we find no statistically significant effects in communities with a nursery and some positive and statistically significant effects in communities without. Thus, our estimated effects are not driven by mothers' SES. This supports the interpretation that the differences in effects across both types of communities are related to the availability of formal versus informal childcare options. Since other community level characteristics also differ between communities with and without formal childcare, we will return to the issue of potential confounders further below in Section 5.3.3.

\subsubsection{Counterfactual work behavior and time with the mother}

We now further refine the analysis by accounting for the fact that the PL extension comprised two important aspects, each of which might impact child development: a change in income and 
a change in the time the mother spends at home with the child. Depending on the mother's counterfactual return-to-work behavior, we can distinguish between two groups of mothers. For mothers who would have remained at home during the second year of the child's life even under the old regime, the treatment implies job protection and a rise in income during the second year. The extended job protection might foster the medium-run labor market attachment of these women. By contrast, for mothers who changed their return-to-work behavior due the reform, the treatment effect captures a change in income, as well as a prolonged period with the child. Since the counterfactual return-to-work behavior is not observable, we cannot unambiguously distinguish between mothers from these the two groups. We use complementary estimation strategies to predict which mothers would have been more or less likely to work in the second year after childbirth in the absence of the reform. ${ }^{35}$

\section{[Figure 6]}

Changes in the time with mother Figure 6 shows maternal employment rates for pre-reform and post-reform mothers by the child's age in communities with and without nurseries. The figure covers the period from 5 years before childbirth to 17 years after. For both types of communities, we observe a similar pattern. During the first year of the child's life, only 3 percent of mothers were employed and thus not on PL. For pre-reform mothers, the employment rate increased only to about 35 percent in the second year of the child's life, implying that 65 percent of mothers stayed at home with their child even in the absence of a PL entitlement. Given that about 9 percent of post-reform mothers worked in the second year despite PL entitlement, the reform increased maternal care for around 26 percent of children in our sample. ${ }^{36}$

\section{[Figure 7]}

Changes in disposable income Figure 7 shows the hypothetical change in maternal income during the second year of the child's life. We take the annual amount of PL benefits and subtract the net income of working pre-reform mothers. ${ }^{37}$ Around 50 percent of mothers had no labor income during this period. For those mothers, disposable income increased by the annual amount of PL benefits $(€ 4,400)$. For mothers who earned an income in the second year, the reform either increased or decreased their disposable income depending on their earnings.

\footnotetext{
${ }^{35}$ This analysis cannot be conducted for educational outcomes since the data lacks information on maternal employment around the time of giving birth.

${ }^{36}$ The employment patterns of mothers in communities with and without nurseries are surprisingly similar in the second year of the child's life. Even in the absence of nurseries, women participated in the labor market, indicating the relevance of informal care arrangements in those communities. Considering full-time employment, the figures differ somewhat. In communities with nurseries around $22 \%$ and in communities without a nursery $18 \%$ of pre-reform mothers worked full-time in the second year.

${ }^{37}$ In this calculation we make the simplifying assumption that all mothers stay at home during the entire second year.
} 
Overall, about 65 percent of the sample experienced an increase in disposable income by on average $€ 3,900$, and 35 percent experienced a decline by on average $€ 8,400$.

Disentangling the two mechanisms Combining the observed changes in labor supply and the hypothetical changes in income, we estimate that about 65 percent of the children in our sample experienced no change in the time with the mother, but an increased disposable income. About 26 percent experienced more time with the mother and a reduction in disposable income. The remaining 9 percent (who worked in the second year despite PL entitlement) experienced a smaller reduction in disposable income due to adaptions along the intensive margin (hours or wages) in the second year of the child's life compared to the pre-birth period.

We now aim to disentangle, whether the observed treatment effects on child outcomes are mainly driven by the increased time with the mother or by the increase in disposable income. To shed light on the importance of time versus income effects, we identify two groups of mothers based on predetermined observable characteristics. This involves the challenge that post-reform mothers are all on parental leave, and that we have to impute their propensity to work based on predetermined observable characteristics. We pursue the following strategy:

- First, we use pre-reform mothers (for which we observe labor supply) and estimate their propensity to work in the second year of the child's life as a function of their predetermined characteristics (e.g., age, education and pre-birth earnings) and their child's birth outcomes.

- Second, we predict the propensity to work in the second year for pre- and post-reform mothers by combining the estimated coefficients from step one with the observable characteristics of all mothers. Put differently, we estimate propensity scores based on observable characteristics for all mothers.

- Third, we split the sample at the median propensity score and test whether the treatment effects on children are driven by mothers with a high or low propensity to work.

To predict the propensity to work, we estimate a linear probability model using a large set of maternal characteristics and birth outcomes. ${ }^{38}$ As expected, mothers with a higher education and higher pre-birth earnings are more likely to work in the second year of the child's life. Moreover, foreign-born mothers and mothers with a religion other than Roman Catholic have a higher propensity to work. Overall, a higher propensity to work is positively correlated with our measure of maternal SES $(r=0.35)$. Table 8 provides summary statistics for mothers with a low and a high estimated propensity to work separately by the availability of a nursery.

\footnotetext{
${ }^{38}$ These variables are mostly taken from the Austrian Birth Register and characterize the time before birth. We use information on birth outcomes (premature birth, child was born with a low birth weight), whether the mother is foreign born, maternal religion, whether the mother is married, maternal education, the mother's occupation, maternal earnings in the last two years before child birth, indicator variables for maternal age at birth ranging from 17 or younger to 35 or older and indicator variables for the province of residency (9 provinces).
} 
Table 9 summarizes the separate estimations for mothers whose characteristics indicate a low and a high propensity to work in communities with and without nurseries. This set of estimations provides the key result of our analysis. We see now that the gains of children in communities without a nursery are driven by mothers with a high propensity to work (i.e., who more likely would have worked in the second year in the absence of the reform). For these children, an additional year of PL increases the likelihood that the child is active at age 17 by 2.7 percentage points, at age 23 by 7.7 percentage points, and for the whole period by 4.9 percentage points. The likelihood that the child is not disabled is raised by 5.1 percentage points. The probability of being fit for military service is increased by almost 19 percentage points. By contrast, the coefficients for children of low work propensity mothers in communities without a nursery are not statistically significant. This finding suggests that the income effect is of secondary importance. In communities with nurseries, none of the coefficients is - irrespective of the mother's propensity to work - statistically significant.

\section{[Table 9]}

These results are robust to a variety of sensitivity checks presented in Appendix Table A.9: (i) variation in covariates (no covariates, more covariates, community-level covariates and quadratic trends), (ii) variation in samples (exclude migrants, bandwidth of 61 days), and (iii) variation in the definition of maternal propensity to work in the second year of the child's life.

To sum up, the statistically significant gains come from children in communities without nurseries, whose mothers more likely would have been working in the counterfactual situation. For this group, the PL reform replaced informal care arrangements with maternal care. This finding suggests that time with the mother is responsible for the gains in child outcomes. ${ }^{39}$

\subsubsection{Falsification tests}

Our estimated treatment effects strongly differ according to the availability of formal childcare at the community level. This heterogeneity may be explained by the counterfactual mode of care. However, we cannot rule out that other community characteristics are the drivers of the observed heterogeneity. Communities without nurseries differ from communities with nurseries in many dimensions: next to differences in maternal characteristics, we see that these communities are smaller and less densely populated, the share of catholics and voters for conservative parties is larger, families have more children, the female employment and labor force participation rate

\footnotetext{
${ }^{39}$ Income effects are less important for child development. The positive effects for children of mothers with a low propensity to work are generally smaller and statistically less significant than our baseline results. This is in line with the findings by Agostinelli and Sorrenti (2018), who study the effect of maternal employment on cognitive and behavioral development in the context of the Earned Income Tax Credit (EITC) program.
} 
is lower and the supply of higher secondary schools is lower (see Table 5). Our robustness tests (summarized in Table 7) have shown that our results hold, even if we condition on a vast set of pre-determined maternal and community-level covariates.

To shed further light on the importance of potentially confounding community characteristics, we pursue the following two strategies. First, we analyze whether the estimated treatment effects simply reflect differences in urbanity or other related community characteristics. We focus on population density, the share of catholics, the share of children aged 0-10 and the female employment rate. We categorize each community into whether it is a low or high type community regarding the particular dimension (based on the median value of this characteristic in the pooled sample). We then re-estimate our main specification including an additional interaction term of the respective community characteristic with PL (and the instrument). If the availability of formal childcare merely reflected, for instance, the degree of urbanity, we would expect that the inclusion of this interaction term reduces or even removes our previously estimated effects. Table 10 shows that our estimates are strikingly similar even after allowing for treatment effect heterogeneity by other community characteristics. Indeed, almost none of the additional interaction effects of PL are statistically significant. The results are robust to the inclusion of all four community characteristics and their interaction with years on parental leave (instrumented by assignment) in one regression (see last Panel of Table 10).

\section{[Table 10]}

Second, we study whether our positive effects in communities without nurseries stem from communities with a higher or lower estimated propensity of formal childcare availability. We first regress our indicator for the availability of nurseries on a set of community characteristics (population density, share of catholics, share of married, share of population aged 0 to 10 , female fulltime employment rate, and the availability of higher secondary schools). These covariates explain about 40 percent of the variation in the availability of nurseries. Based on the estimated coefficients, we predict the propensity of formal childcare availability for each community. We then estimate separate effects for communities with above and below median propensity scores (within the sample of communities without nursery). If confounding community characteristics are not driving our results, we expect to find positive effects independent of the propensity score. Table A.10 shows that we find some positive and significant effects of parental leave for high work propensity mothers in both types of communities (depending on the outcome).

These falsification tests provide evidence that the availability of formal childcare and not other potentially confounding community characteristics are the source of the observed treatment effect heterogeneity. 


\subsection{Fertility, maternal labor supply, and family stability}

PL policies affect the relative costs of child-bearing and may therefore alter fertility decisions, maternal labor supply, and marriage behavior. Indeed, the 1990 Austrian PL reform caused a delay in maternal return to work, an increase in fertility and a change in the spacing of births (Lalive and Zweimüller, 2009; Lalive, Schlosser, Steinhauer and Zweimüller, 2014). Increased family size might reduce parental monetary and time investments into the child or affect child outcomes through adjusted maternal labor supply and family income. Moreover, extended PL may alter specialization within the household, the bargaining power of spouses, and marital stability. To shed some light on the effects of these potential mediators, we estimate the effects of the reform on fertility, maternal labor supply, and family stability.

Fertility Figure 8 show the estimated coefficients and 95 percent confidence intervals obtained by 2SLS regressions of PL duration on the probability that the mother give birth to a further child (Panel A) and on the number of children (Panel B) up to 17 years after treatment for women in communities with and without nurseries.

\section{[Figure 8]}

We find some evidence on short term fertility effects. Mothers are more likely to have a further child after three years in communities with a nursery and after two years in communities without. These coefficients are statistically significant at the 10-percent-level (see Appendix Table A.11). Turning to the number of children, we find no significant effects of the PL reform on family size in communities with nurseries. The estimated coefficients are positive and large in magnitude but statistically not significant. In communities without nurseries, we find no evidence on fertility effects in the medium and long run.

Maternal labor supply Extended PL might affect maternal labor supply. Figure 8 show the estimated coefficients of PL on the probability that the mother is employed (Panel C) and fulltime employed (Panel D) in each year of the child's life. The additional year of PL has similar negative effects on maternal labor supply in the second year of the child's life in both types of communities (33 and 31 percentage points). These results confirm the descriptive evidence presented in Figure 6. After the extended PL period has expired, we find a short term reduction in maternal employment in communities with nurseries. This is in line with our findings on short term fertility in those communities.

Our analysis of maternal labor supply at the intensive margin uncovers long-lasting effects on mothers in communities without nurseries. As expected, the reform reduced maternal full-time employment in the second year of the child's life in all communities. Beyond the second year, a diverging pattern emerges across communities with and without nurseries. In communities with nurseries, we find almost no significant effects on maternal full-time employment and all coefficients are negative. By contrast, we observe significant positive effects for mothers in communities without nurseries. These mothers are up to 10 percentage points more likely to 
work in a full-time job in the long run. This result seems surprising at first glance, but is plausible. Extended PL should help women return to work. In communities without nurseries, women may be more likely to use their right to return to their job after two years as opposed to one year. Furthermore, the somewhat reduced spacing of births between the first and second children might reduce the overall absence from work, thereby assisting the return to a permanent career. Another explanation is that mothers might react to their children's needs. Maternal labor supply increases at the intensive margin because mothers are able to work more in the absence of child development problems.

Family stability Figure 9 summarizes the results on family status. Panel A shows the effects of PL on the probability that the mother is currently married. None of the coefficients is statistically significant at conventional levels. Panels B and C show separate estimations for mothers by marital status at the time of birth. ${ }^{40}$ No significant results are obtained for mothers married at birth, indicating that the probability of divorce has not been influenced by the PL reform. For mothers unmarried at birth, the reform increased the probability of getting married in communities with nurseries in the first three years after birth. This result is in line with our findings on short term fertility in those communities. The birth of a second child is accompanied by an increase in marriages. In communities where nurseries are not available, no comparable effect is observed.

\section{[Figure 9]}

Overall, our analysis shows that extended PL affects the family environment in which children grow up. The local availability of formal childcare seems to be a central component in shaping the impact of PL. Mothers in communities where formal childcare is available reacted to the reform with an increase in short term fertility, a decrease in labor supply on the extensive margin, no effect on long-run full-time employment, and an increased propensity to get married in the short term. Mothers in communities without formal childcare reacted differently to the reform. Apart from a differential spacing between births, these women did not alter their labor market participation but increased their full-time employment in the medium and long run. Furthermore, they did not change their marriage behavior.

\subsubsection{Child outcomes revisited}

We find zero effects of extended PL for children in communities with nurseries and positive effects in communities without. Our evidence suggests that the counterfactual mode of care drives this heterogeneity. In this final section, we explore the role of potential mediators. As discussed in the previous section, the reform increased short run fertility and reduced short run

\footnotetext{
${ }^{40}$ About 62 percent of the children were born legitimate and the other 38 percent were born out of wedlock. This distribution is quite comparable across communities. 68 and 60 percent in communities with and without nurseries were born to a married mother.
} 
labor supply at the extensive margin in communities with nurseries. Thus, reduced parental monetary and time investments into the child due to a quantity/quality trade-off might explain the zero treatment effects for children in those communities. Accordingly, the positive effects in communities without a childcare facility might stem from the positive effects of the reform on long-run maternal full-time employment, which boosts family income. These women also reduced the spacing between the first and second children somewhat.

\section{[ Table 11]}

Table 11 shows the sensitivity of our estimates on child outcomes to the inclusion of controls for family size and maternal (full-time) employment in the third, fifth and 10th years of the child's life. Considering the endogeneity of these variables, we evaluate the sensitivity of our estimated treatment effects with respect to the inclusion of these controls. If the positive effects in communities without nurseries are mainly driven by maternal full-time employment and income effects, the coefficients of PL should decrease in magnitude when maternal (fulltime) employment is controlled for. The same applies to family size: if short term fertility effects are the main reason why the PL extension does not show any positive effects on children in communities with nurseries, controlling for family size should alter the estimated effects.

Such a mediation analysis is valid only if the assumption of sequential ignorability holds (Imai et al., 2011). This assumption involves that (i) treatment assignment is independent of potential outcomes and potential mediators, and (ii) any mediators are as good as randomly assigned conditional on treatment status and predetermined characteristics. The first assumption is fulfilled because we only use variation in PL duration that is due to assignment to the reform. Therefore, we can identify the causal effects of the treatment on child outcomes and the mediators (fertility and maternal labor supply). The second assumption does not automatically hold even if the treatment is randomly assigned. In our context, this assumption implies that among mothers, who share the same treatment status (for instance, long PL due to assignment to the reform) and the same predetermined characteristics, the mediators are randomly assigned, i. e., fertility and labor supply are not determined by unobserved characteristics. Whether this assumption is valid cannot be tested; thus, the estimated effects of PL conditional on fertility and maternal labor supply have to interpreted with caution.

It turns out that the treatment effects for children in communities with and without formal childcare are not sensitive to the inclusion of these mediating variables. This suggests that the differential effects of the PL reform on short term fertility and maternal (full time) employment across communities do not drive the heterogeneity in the effects on child outcomes. ${ }^{41}$

Overall, family size and maternal employment do not seem to be important mediators of the PL reform. The estimated treatment effects on children most likely have other origins,

\footnotetext{
${ }^{41}$ Appendix Table A.18 repeats the analysis additionally accounting for the counterfactual maternal labor supply in the second year after child birth. Again, we find no evidence that the inclusion of control variables for maternal labor supply and family size significantly affects our main results provided in Table 9.
} 
namely, PL in the second year of the child's life per se and the replacement of pre-reform care arrangements. Figure 10 summarizes the estimated treatment effects from our baseline model and all the robustness tests, showing the treatment effect heterogeneity according to the availability of nurseries across all estimation models.

[Figure 10]

\section{Conclusions}

Who should provide care to young children? Public policy makers reveal their preferences by promoting different institutions. Parental leave policies implicitly assume that parents are the best caregivers for very young children. In contrast, a policy promoting nurseries reveals a preference for non-parental care provided in a formal setting. A lack of any care-related public policy may reflect the view that children of working parents should rely on informal care settings. Given the potentially large consequences of early care and education on individual outcomes throughout the life cycle, the childcare decision should be guided by sound empirical evidence.

Exploiting a parental leave reform — which as good as randomly assigned Austrian families to either one or two years of parental leave — we provide evidence that maternal care during the child's second year of life improves children's long-term health outcomes (as compared to the average alternative mode of care). In cases where maternal care replaced informal care arrangements, the health gains are substantially larger and significant gains are also present in the domain of long-term human capital outcomes. This suggest that maternal care is superior to informal care. Potential causal channels are the higher level of stability, increased awareness for early interventions, or an overall reduced level of parenting stress.

Our research design is less-well suited to compare maternal care with formal care. Our preliminary evidence suggests that these two modes of care are very comparable in their impact on long-term child outcomes. This finding is in line with the literature on formal childcare, which finds zero (or positive) effects of formal childcare and mostly negative effects of informal childcare compared with maternal care.

Our study yields important insights for the ongoing policy debate related to policies aimed at helping mothers to reconcile family and working life, in particular child-related leave schemes. Around the globe, these leave policies are in a constant state of flux as governments adjust the length and level of benefits, the duration of job protection and the flexibility of the schemes. ${ }^{42}$

\footnotetext{
${ }^{42}$ In the period from May 2018 to April 2019, 22 out of 43 countries covered in the review by Koslowski et al. (2019) amended their maternity, paternity or parental leave legislation. From 1970 to 2018 the average total length of national paid maternity, parental and childcare leave available to mothers increased from about 17 to 51 weeks in OECD countries. Paid childcare leave - also called cash-for-care or home-care-leave - is offered by several countries as a supplement to parental leave, and allows parents to extend the period of leave beyond the child's first birthday (Koslowski et al., 2019). In 2018, 12 OECD countries offered mothers a maximum paid
} 
Our results are most relevant for settings with high parental labor force participation rates on the one hand, but no or only rationed supply of formal childcare for toddlers on the other hand. Under these conditions, many working parents (have to) rely on informal childcare arrangements, mainly provided by grandparents. ${ }^{43}$ According to recent international statistics, the number of countries for which this is the case is large. Across European countries, employment rates of mothers of 0-to-2-year-olds surpass corresponding enrolment rates in formal childcare on average by 37 percent, indicating that a substantial fraction of working mothers of very young children rely predominantly on other, informal care arrangements (see Appendix Table A.20). Survey evidence reveals that almost 30 percent of all 0 -to-2-year-olds are being cared for by their grandparents, relatives, friends or neighbors, for about 17 hours, in a typical week (OECD Family Database, PF3.3). Informal childcare plays also a very important role in the United States. National estimates for 2012 show that about one-half all 1-year-olds are exclusively cared for by their parents; the other half receives non-parental care on a regular, weekly basis (National Survey of Early Care and Education Project Team, 2016). Only 25 percent of the latter comes in the form of formal, center-based early care and education. $75 \%$ of the non-parental care is by informal care providers - mostly unpaid care by grandparents and relatives - for about 30 hours per week, on average. Our findings suggest that in institutional settings with a large extent of informal care for 1-year-olds, parental leave has the potential to lead to long-run gains in child outcomes, while having no negative (or even positive) effects on maternal labor supply, family stability and fertility.

leave of more than one year (see Appendix Table A.19). Hence, granting paid child-related leave beyond the child's first birthday appears to be a feasible and relevant policy option for a large group of countries.

${ }^{43}$ Several studies show that (early) maternal employment is affected by the availability of grandparental childcare (see short review by Zanella (2017)). 


\section{References}

Agostinelli, Francesco and Giuseppe Sorrenti (2018), Money vs. Time: Family Income, Maternal Labor Supply, and Child Development, Working Paper 273, University of Zurich.

An, Ruopeng, Xiaoling Xiang, Na Xu and Jing Shen (2020), 'Influence of Grandparental Child Care on Childhood Obesity: A Systematic Review and Meta-Analysis', Childhood Obesity 16(3), 141-153.

Baker, Michael, Jonathan Gruber and Kevin Milligan (2008), 'Universal Childcare, Maternal Labor Supply, and Family Well-Being', Journal of Political Economy 116(4), 709-745.

Baker, Michael and Kevin Milligan (2010), 'Evidence from Maternity Leave Expansions of the Impact of Maternal Care on Early Child Development', Journal of Human Resources 45(1), 1-32.

Baker, Michael and Kevin Milligan (2015), 'Maternity Leave and Children's Cognitive and Behavioral Development', Journal of Population Economics 28(2), 373-391.

Behrman, Jere R., Yingmei Cheng and Petra E. Todd (2004), 'Evaluating Preschool Programs When Length of Exposure to the Program Varies: A Nonparametric Approach', The Review of Economics and Statistics 86(1), 108-132.

Bernal, Raquel and Michael P. Keane (2011), 'Child Care Choices and Children's Cognitive Achievement: The Case of Single Mothers', Journal of Labor Economics 29(3), 459-512.

Bettinger, Eric, Torbjrn Hgeland and Mari Rege (2014), 'Home with Mom: The Effects of Stay-at-Home Parents on Children's Long-Run Educational Outcomes', Journal of Labor Economics 32(3), 443-467.

Black, Lindsay, K. Matvienko-Sikar and P.M. Kearney (2017), 'The Association between Childcare Arrangements and Risk of Overweight and Obesity in Childhood: A Systematic Review', Obesity Reviews 18(10), 1170-1190.

Bono, Emilia Del, Marco Francesconi, Yvonne Kelly and Amanda Sacker (2016), 'Early Maternal Time Investment and Early Child Outcomes', The Economic Journal 126(596), F96F135.

Boyle, Coleen A., Sheree Boulet, Laura A. Schieve, Robin A. Cohen, Stephen J. Blumberg, Marshalyn Yeargin-Allsopp, Susanna Visser and Michael D. Kogan (2011), 'Trends in the Prevalence of Developmental Disabilities in US Children, 1997-2008', Pediatrics 127(6), 1034-1042.

Buckles, Kasey S. and Daniel M. Hungerman (2013), 'Season of Birth and Later Outcomes: Old Questions, New Answers', Review of Economics and Statistics 95(3), 711-724. 
Campbell, Frances, Gabriella Conti, James J. Heckman, Seong Hyeok Moon, Rodrigo Pinto, Elizabeth Pungello and Yi Pan (2014), 'Early Childhood Investments Substantially Boost Adult Health', Science 343(6178), 1478-1485.

Carneiro, Pedro, Katrine V. Løken and Kjell G. Salvanes (2015), 'A Flying Start? Maternity Leave Benefits and Long Run Outcomes of Children', Journal of Political Economy $\mathbf{1 2 3}(2), 365-412$.

Cornelissen, Thomas, Christian Dustmann, Anna Raute and Uta Schönberg (2018), 'Who Benefits from Universal Child Care? Estimating Marginal Returns to Early Child Care Attendance', Journal of Political Economy 126(6), 2356-2409.

Cunha, Flavio, James J. Heckman, Lance Lochner and Dimitry V. Masterov (2006), Interpreting the Evidence on Life Cycle Skill Formation, in E. A.Hanushek and F.Welch, eds, 'Handbook of the Economics of Education', Vol. 1, North Holland, chapter 12, pp. 697-812.

Dahl, Gordon, Katrine V. Løken, Magne Mogstad and Kari Salvanes (2016), 'What Is the Case for Paid Maternity Leave?', Review of Economics and Statistics 98(4), 655-670.

Danzer, Natalia and Victor Lavy (2018), 'Paid Parental Leave and Children's Schooling Outcomes', Economic Journal 128(608), 81-118.

Datta-Gupta, Nabanita and Marianne Simonsen (2010), 'Non-cognitive Child Outcomes and Universal High Quality Child Care', Journal of Public Economics 9(1-2), 30-43.

Dickert-Conlin, Stacy and Amitabh Chandra (1999), 'Taxes and the Timing of Births', Journal of Political Economy 107(1), 161-177.

Drange, Nina and Mari Rege (2013), 'Trapped at Home: The Effect of Mothers' Temporary Labor Market Exits on their Subsequent Work Career', Labour Economics 24, 125-136.

Drange, Nina and Tarjei Havnes (2019), 'Early Child Care and Cognitive Development: Evidence from an Assignment Lottery', Journal of Labor Economics 37(2), 581-620.

Dustmann, Christian and Uta Schönberg (2012), 'Expansions in Maternity Leave Coverage and Children's Long-Term Outcomes', American Economic Journal: Applied Economics $4(3), 190-224$.

Elango, Sneha, Andrés Hojman, Jorge Luis García and James Heckman (2016), Early Childhood Education, in R.Moffitt, ed., 'Means-Tested Transfer Programs in the United States, Volume II', Chicago: University of Chicago Press.

Felfe, Christina and Rafael Lalive (2018), 'Does Early Child Care Affect Children's Development?', Journal of Public Economics 159, 33-53. 
Fitzpatrick, Maria D. (2008), 'Starting School at Four: The Effect of Universal PreKindergarten on Children's Academic Achievement', The B.E. Journal of Economic Analysis 8 Policy (Advances) 8(1), 46-46.

Fort, Margaritha, Andrea Ichino and Giulio Zanella (forthcoming), 'Cognitive and NonCognitive Costs of Daycare 0-2 for Girls', Journal of Political Economy .

Frandsen, Brigham R. (2017), Party Bias in Union Representation Elections: Testing for Manipulation in the Regression Discontinuity Design When the Running Variable is Discrete, in M.Cattaneo and J.Escanciano, eds, 'Regression Discontinuity Designs: Theory and Applications', Vol. 38, Emerald Publishing, pp. 281-315.

Gathmann, Christina and Björn Sass (2018), 'Taxing Childcare: Effects on Childcare Choices, Family Labor Supply and Children', Journal of Labor Economics 36(3), 665-709.

Gregg, Paul and Jane Waldfogel (2005), 'Symposium on Parental Leave, Early Maternal Employment and Child Outcomes: Introduction', Economic Journal 115(501), F1-F6.

Havnes, Tarjei and Magne Mogstad (2011), 'No Child Left Behind: Subsidized Child Care and Children's Long-Run Outcomes', American Economic Journal: Economic Policy 3(2), 97129.

Herbst, Chris M. (2013), 'The Impact of Non-Parental Child Care on Child Development: Evidence from the Summer Participation', Journal of Public Economics 105(1), 86-105.

Hiilamo, Heikki, Marko Merikukka and Anita Haataja (2018), 'Long-Term Educational Outcomes of Child Care Arrangements in Finland', SAGE Open 8(2), 1-15.

Imai, Kosuke, Luke Keele, Dustin Tingley and Teppai Yamamoto (2011), 'Unpackking the Black Box of Causality: Learning about Causal Mechanisms from Experimental and Observational Studies', American Political Science Review 105(4), 765-789.

Kline, Patrick and Christopher R. Walters (2016), 'Evaluating Public Programs with Close Substitutes: The Case of Head Start', Quarterly Journal of Economics 131(4), 1795-1848.

Koslowski, Alison, Sonja Blum, Ivana Dobrotić, Alexandra Macht and Peter Moss (2019), 15th International Review of Leave Policies and Research 2019, Technical report, International Network of Leave Policies and Research.

Kosonen, Tuomas (2014), 'To Work or Not to Work? The Effect of Childcare Subsidies on the Labour Supply of Parents', The B.E. Journal of Economic Analysis 8 Policy 14(3), 817-848.

Kottelenberg, Michael J. and Steven F. Lehrer (2017), 'Targeted or Universal Coverage? Assessing Heterogeneity in the Effects of Universal Child Care', Journal of Labor Economics $35(3)$. 
Lalive, Rafael, Analİa Schlosser, Andreas Steinhauer and Josef Zweimüller (2014), 'Parental Leave and Mothers' Careers: The Relative Importance of Job Protection and Cash Benefits', Review of Economic Studies 81(1), 219-265.

Lalive, Rafael and Josef Zweimüller (2009), 'How Does Parental Leave Affect Fertility and Return to Work? Evidence from Two Natural Experiments', Quarterly Journal of Economics 124(3), 1363-1402.

Lidgate, Eleanor D., Bai Li and Antje Lindenmeyer (2018), 'A Qualitative Insight into Informal Childcare and Childhood Obesity in Children Aged 0-5 Years in the UK', BMC Public Health 18(1229).

Liu, Qian and Oskar Nordström Skans (2010), 'The Duration of Paid Parental Leave and Children's Scholastic Performance', B. E. Journal of Economic Analysis and Policy 10(1), 135.

Morrissey, Taryn W. (2009), 'Multiple Child-Care Arrangements and Young Children's Behavioral Outcomes', Child Development 80(1), 59-76.

National Survey of Early Care and Education Project Team (2016), Early Care and Education Usage and Households' Out-of-pocket Costs: Tabulations from the National Survey of Early Care and Education (NSECE), OPRE Report 2016-09, Office of Planning, Research and Evaluation, Administration for Children and Families, U.S. Department of Health and Human Services, Washington, DC.

Noboa-Hidalgo, Grace E. and Sergio S. Urzùa (2012), 'The Effects of Participation in Public Child Care Centers: Evidence from Chile', Journal of Human Capital 6(6), 1-34.

Parkes, Alison, Helen Sweeting and Daniel Wight (2015), 'Parenting Stress and Parent Support Among Mothers With High and Low Education', Journal of Family Psychology 29(6), 907918.

Rasmussen, Astrid (2010), 'Increasing the Length of Parents' Birth-Related Leave: The Effect on Children's Long-Term Educational Outcomes', Labour Economics 17(1), 91-100.

Rossin-Slater, Maya (2018), Maternity and Family Leave Policy, in L. M. A.Susan L. Averett and S. D.Hoffman, eds, 'Oxford Handbook of Women and the Economy', New York: Oxford University Press, pp. 323-343.

Schneeweis, Nicole and Martina Zweimüller (2012), 'Girls, Girls, Girls: Gender Composition and Female School Choice', Economics of Education Review 31(4), 482-500.

Schneeweis, Nicole and Martina Zweimüller (2014), 'Early Tracking and the Misfortune of Being Young', Scandinavian Journal of Economics 116(2), 394-428. 
Statistik Austria (1990), 'Mikrozensus 1990'. Statistik Austria, Vienna.

Statistik Austria (2008), 'Jahrbuch der Gesundheitsstatistik 2008'. Statistik Austria, Vienna.

Walters, Christopher R. (2015), 'Inputs in the Production of Early Childhood Human Capital: Evidence from Head Start', American Economic Journal: Applied Economics 7(4), 76-102.

Zanella, Giulio (2017), 'How Does Grandparent Childcare Affect Labor Supply?', IZA World of Labor 337.

Zhang, Chi and Shunsuke Managi (2020), 'Functional Social Support and Maternal Stress: A Study on the 2017 Paid Parental Leave Reform in Japan', Economic Analysis and Policy 65, 153-172.

Zweimüller, Josef, Rudolf Winter-Ebmer, Rafael Lalive, Andreas Kuhn, Jean-Philippe Wuellrich, Oliver Ruf and Simon Büchi (2009), The Austrian Social Security Database (ASSD), Working Paper 0901, The Austrian Center for Labor Economics and the Analysis of the Welfare State, University of Linz. 


\section{Figures and Tables (to be placed in the paper)}

Figure 1: Enrolment rates in formal childcare (in percent, sample: communities with nurseries)

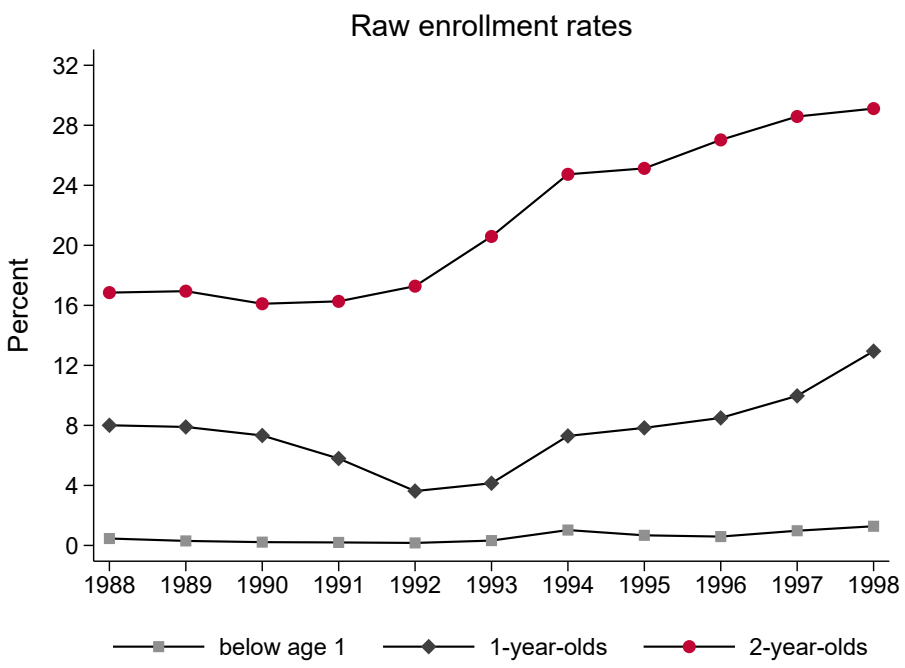

Enrollment rates adjusted for maternal employment 1-year-old children

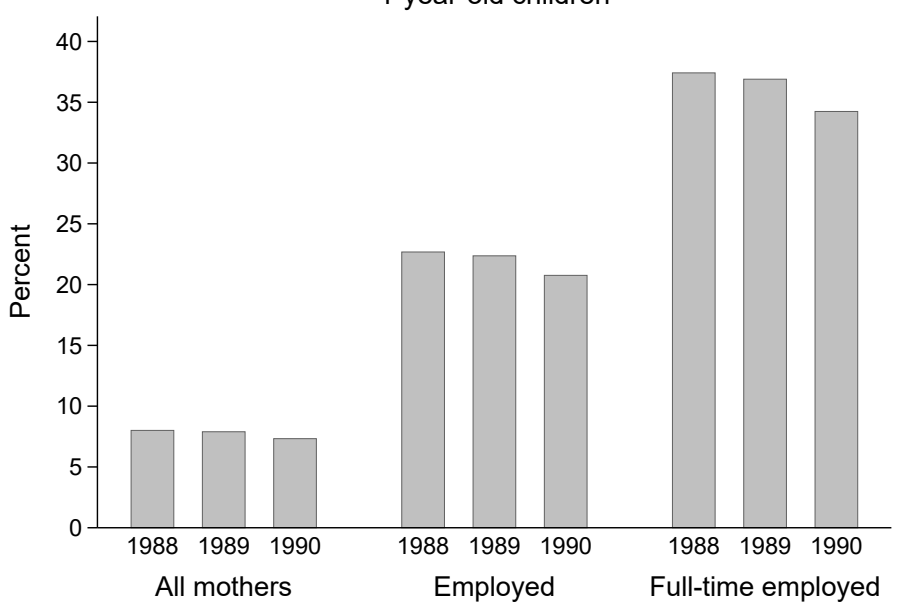

Notes: Own calculations based on data from Kindertagesheimstatistik (Statistics Austria, Statcube, retrieved on November 17, 2016) and the Austrian Birth Register. All figures refer to communities with a nursery. Raw enrolment rates are calculated as the ratio between the number of enrolled children by age and the number of children in the respective birth cohort (expressed in percent). Between 1993 and 1994 the definition of age groups has changed: The age-definition is based on calendar years (January 1 to December 31) up until 1993. From 1994 onwards, the age-definition is based on school years (September 1 to August 31). Higher enrolment rates after 1994 are partly due to the fact that the age-groups consist of slightly older children. Furthermore, data problems occurred in 1993, thus, data-points for this year have to be taken with care. Enrolment rates adjusted for maternal employment are calculated by multiplying the denominator of the raw enrolment rate of 1-year-old children with the (full-time) employment rate of pre-reform mothers in the second year of the child's life (35 and 21 percent). Since the numerator contains children of full- and part-time working mothers, the estimated enrolment rates of children of full-time employed mothers are upper bounds. 
Figure 2: PL duration, eligibility and takeup rate by date of birth

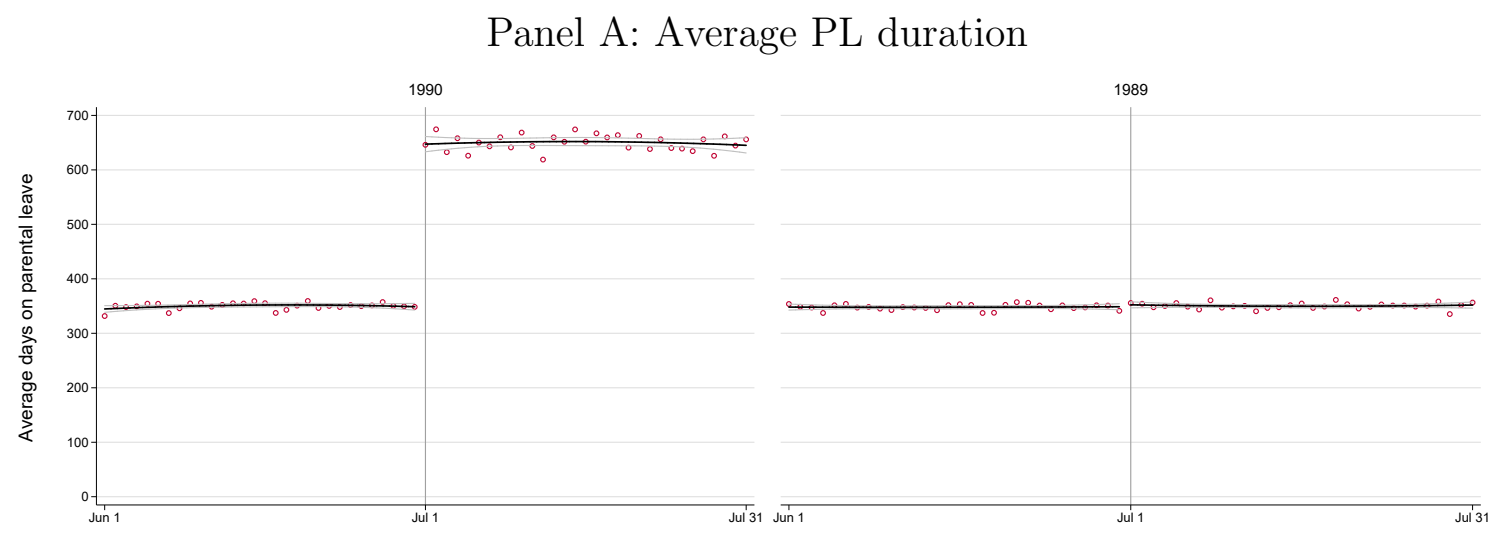

Panel B: Average eligibility rate

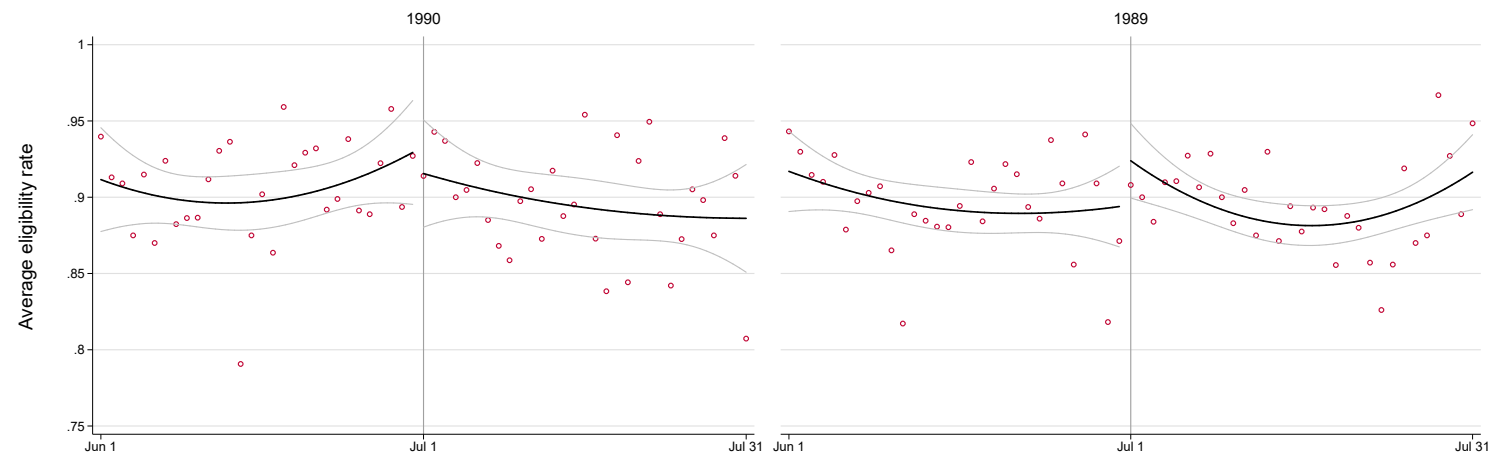

Panel C: Average takeup rate

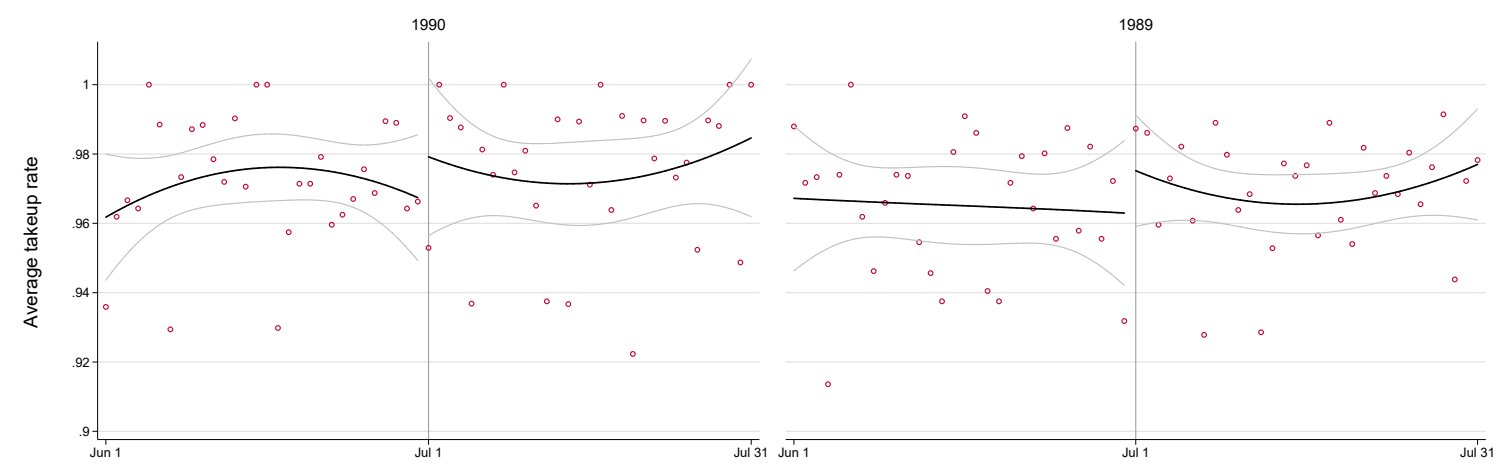

Notes: These figures show daily averages (by date of birth) of three different variables for June and July in the year of the reform (1990), and in the year before the reform (1989) with a second degree polynomial fit. Panel A depicts the average days on PL. This resembles our first-stage relationship. Panel B depicts the average eligibility rate. Panel $\mathrm{C}$ depicts the average takeup rate. 


\section{Figure 3: Density of the running variable}

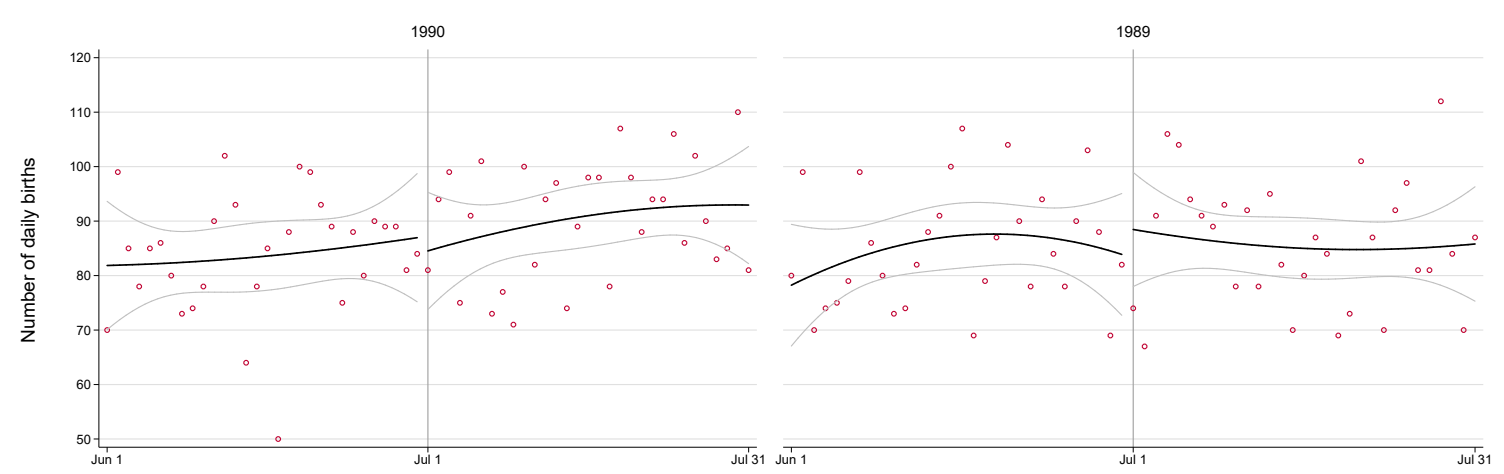

Notes: These figures show the number of daily births in June and July in the year of the reform (left Panel), and in the year before the reform (right Panel) with a second degree polynomial fit. Both figures show no evidence of a discontinuity at the cutoff birthday date on July 1. The manipulation test for discrete running variables as suggested by Frandsen (2017) gives p-values of 0.53 for 1990 and 0.97 for $1989(k=0)$. 
Figure 4: RD plots of predetermined characteristics
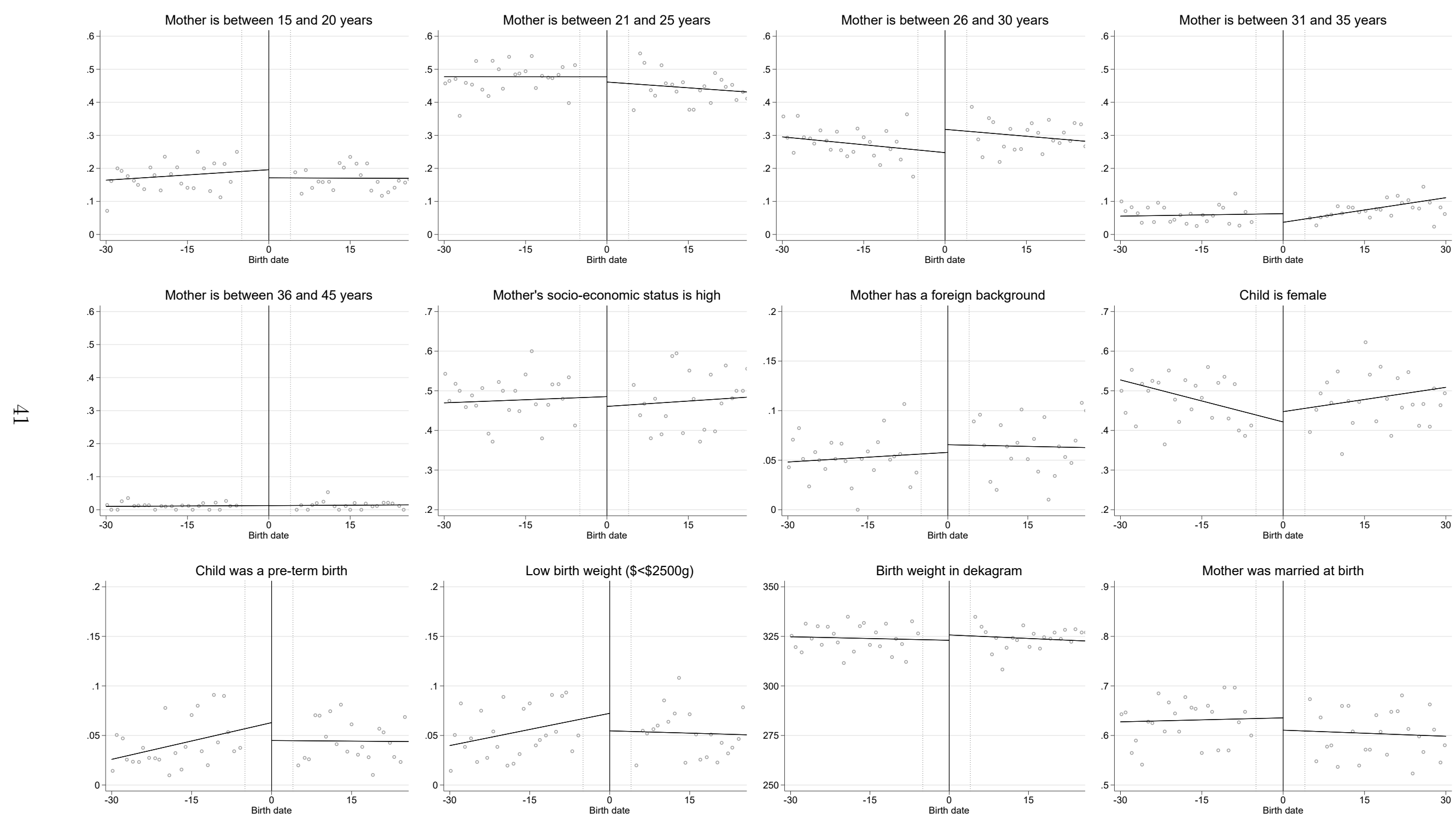

Notes: Variance RD plots with evenly-spaced bins. Circles are local sample means within bins. The solid line is a fitted triangular local linear regression with a bandwidth of 30 days (exluding observations \pm 5 days around the cutoff). 
Figure 5: Sensitivity with respect to bandwidth choice

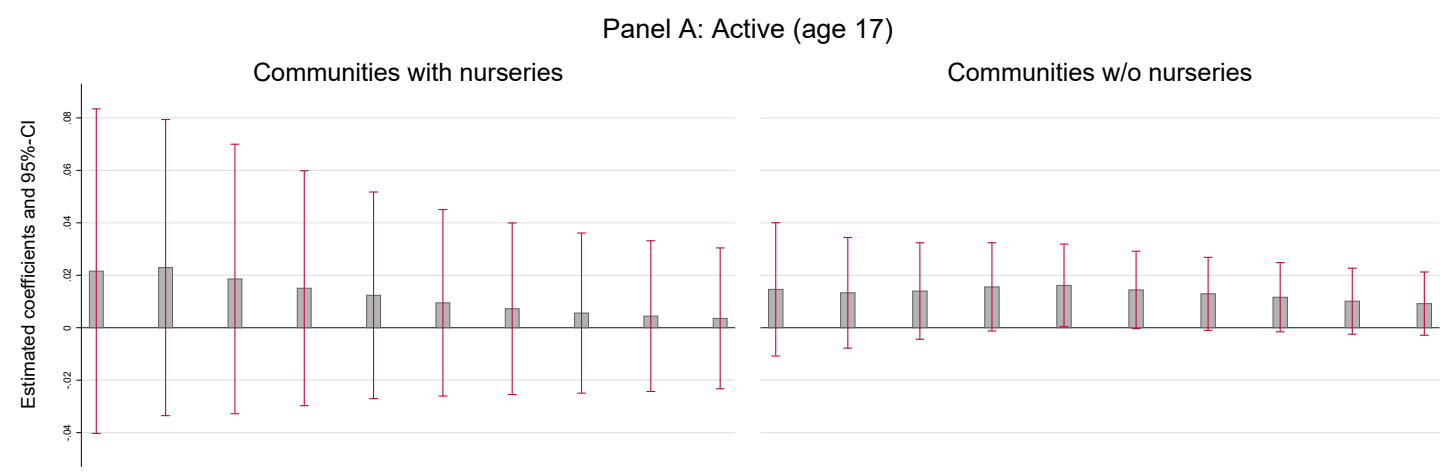

Panel B: Active (age 23)

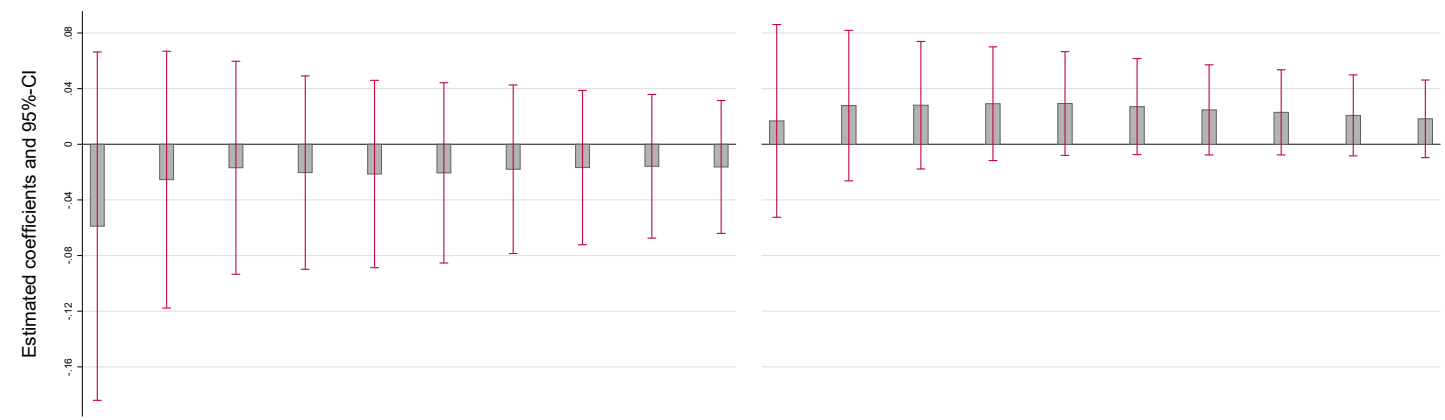

Panel C: Active (age 17-23)
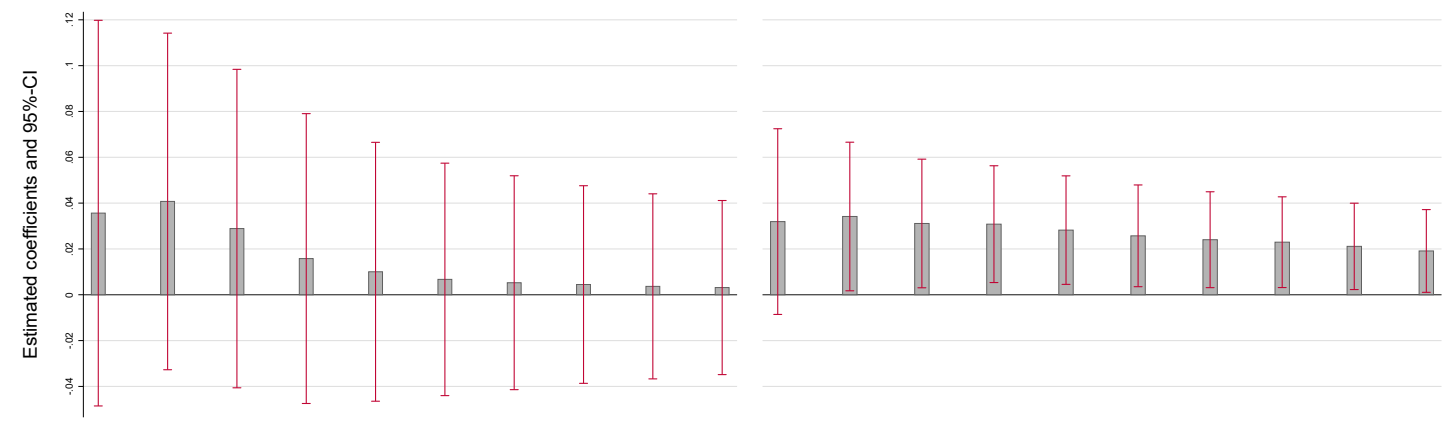

Panel D: Non-disabled

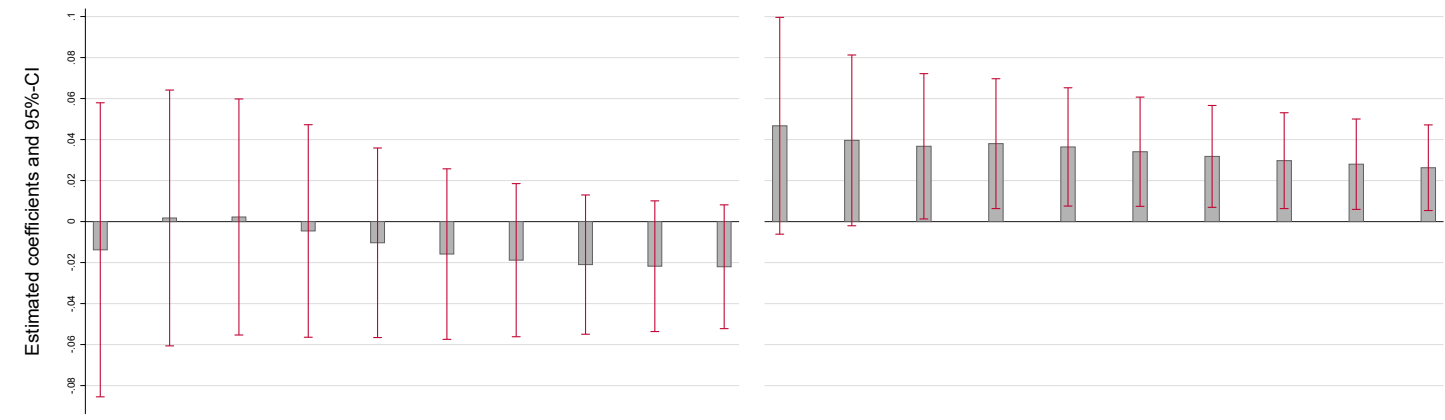

Panel E: Fit for military (boys)
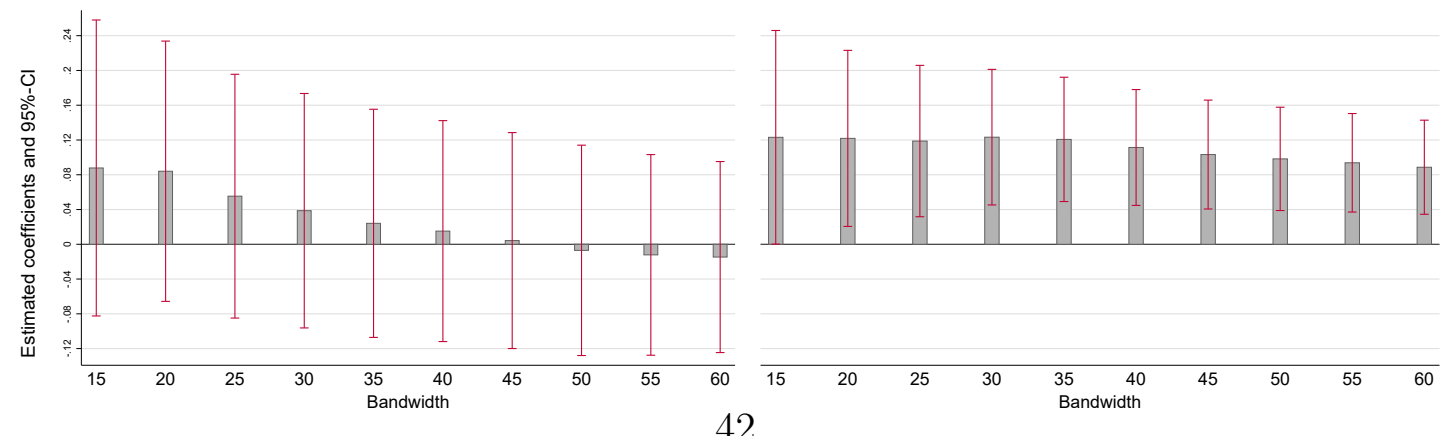


\section{Figure 6: Return to work after childbirth}
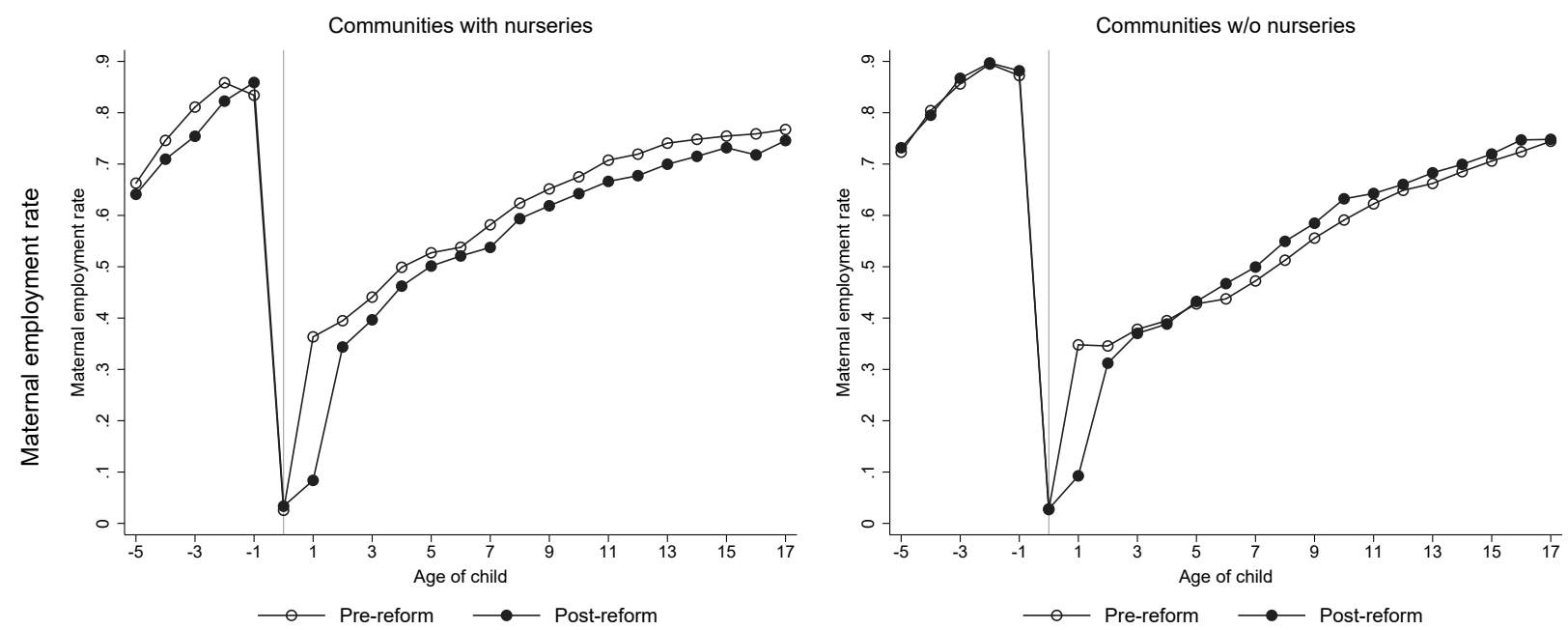

Notes: Employment rates are calculated for our sample of PL eligible first time mothers whose children were born in June/July 1989/1990 (excluding \pm 5 days around the cutoff). Employment is measured on January $1^{\text {st }}$ in each year and shown separately for pre-reform and post-reform mothers in communities with and w/o nursery.

Figure 7: Changes in disposable income

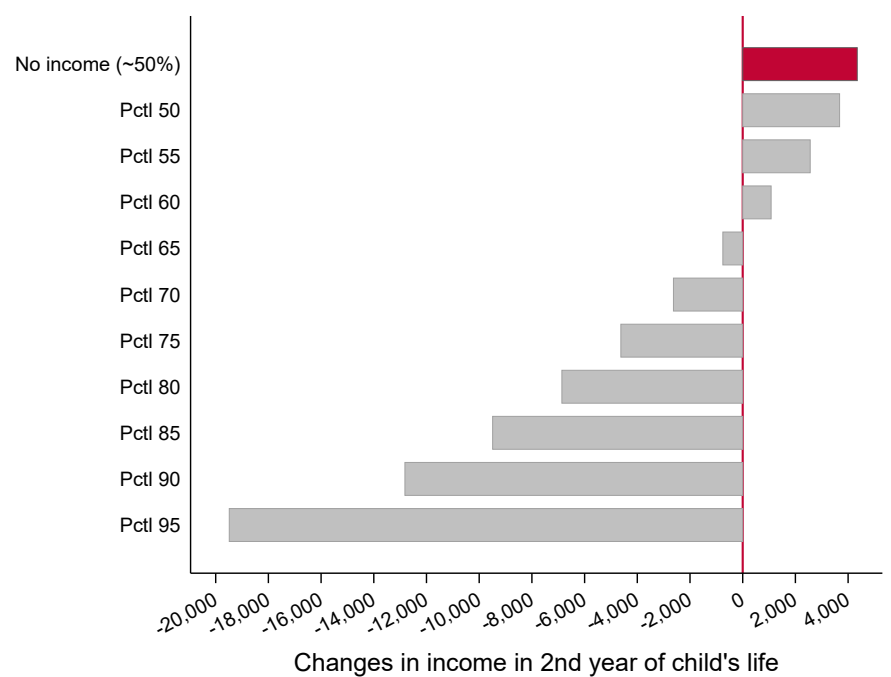

Notes: This figure shows the hypothetical change in disposable income due to the reform for mothers at different points in the income distribution. These income changes are approximated as follows: we take the annual amount of PL benefits and subtract the real net earnings of pre-reform mothers (i. e., first time mothers, who are eligible for PL) in the second year of the child's life, which are calculated as gross earnings minus social insurance contributions and income taxes. 
Figure 8: Fertility and maternal labor supply up to 17 years after childbirth
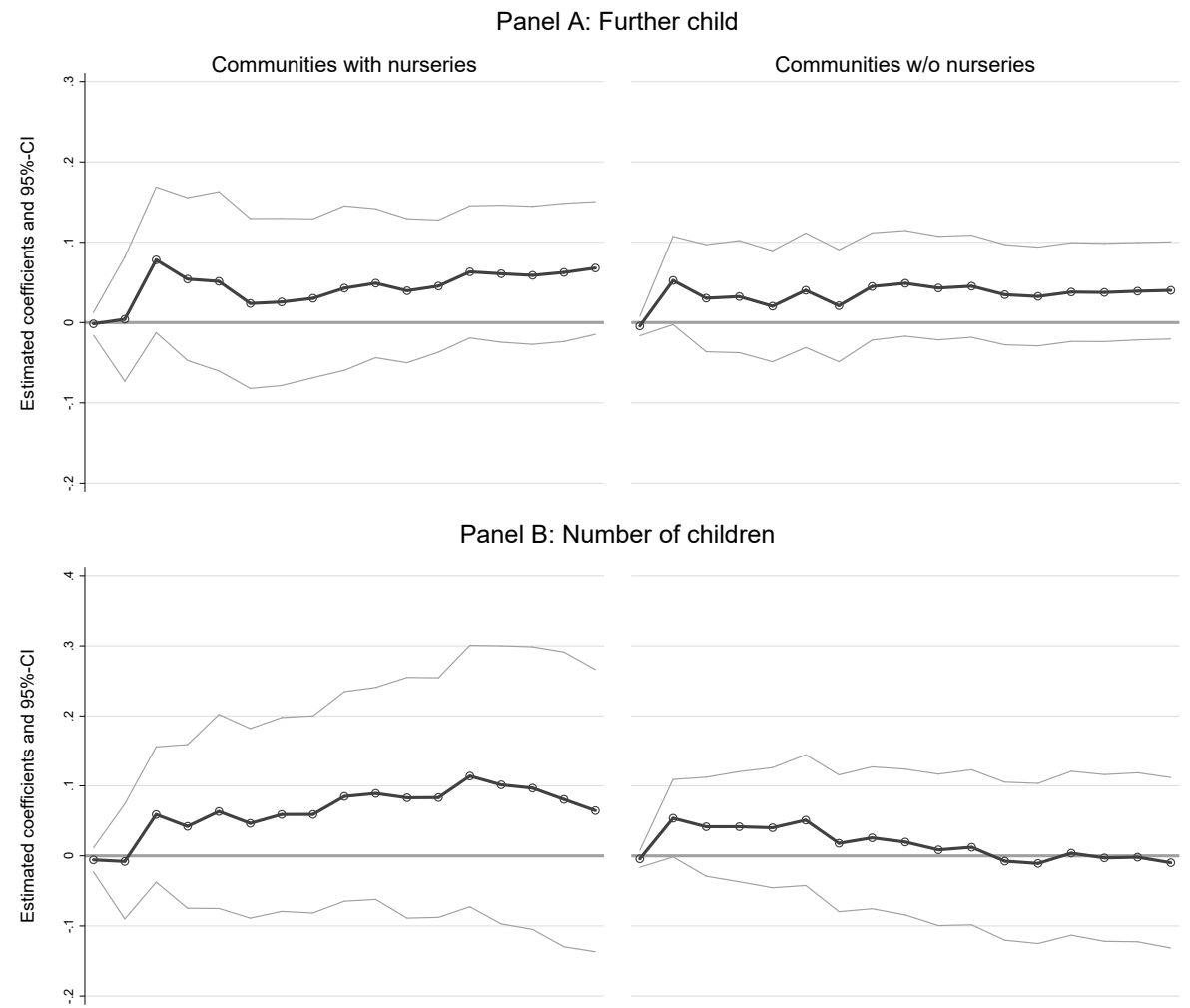

Panel C: Maternal employment

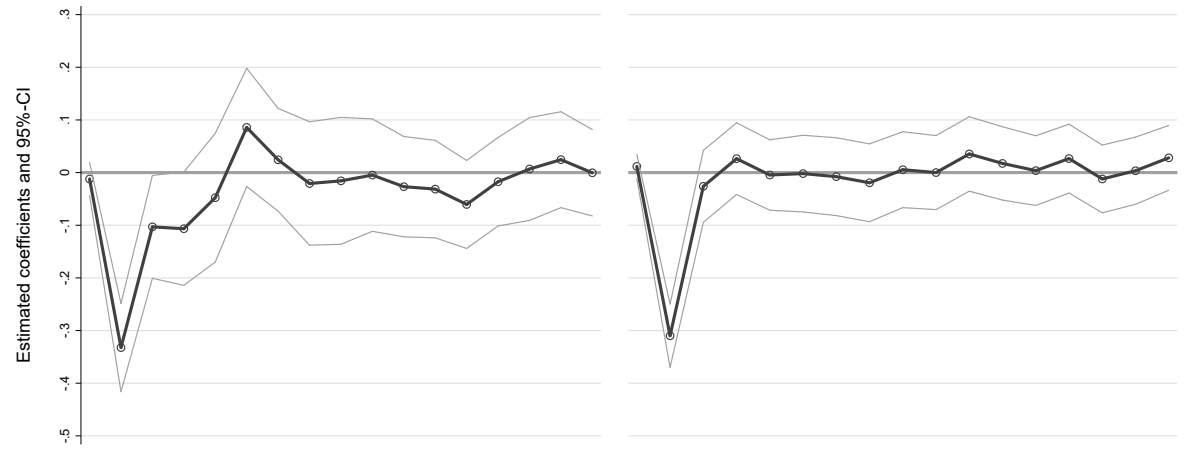

Panel D: Maternal full-time employment

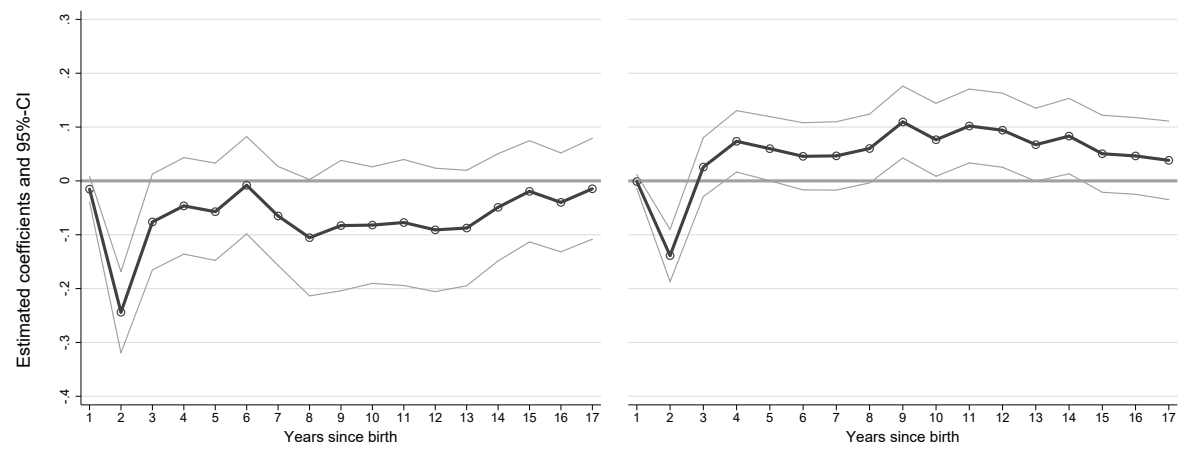

Notes: This figure shows the estimated coefficients and 95\% confidence intervals from separate 2SLS regressions with years on PL instrumented by the assignment to the reform. Further child (Panel A) is the probability that the mother has a further child at the first child's birthday in each year. Number of children (Panel B) is measured as the number of children at the first child's birthday in each year. Maternal labor supply is measured as the probability to be employed (Panel C) and the probability to be employed full-time (Panel D) in each year of the child's life. See Appendix Tables A.11, A.12, A.13 and A.14 for full regression output and further information. 


\section{Figure 9: Family status (currently married) up to 17 years after childbirth}

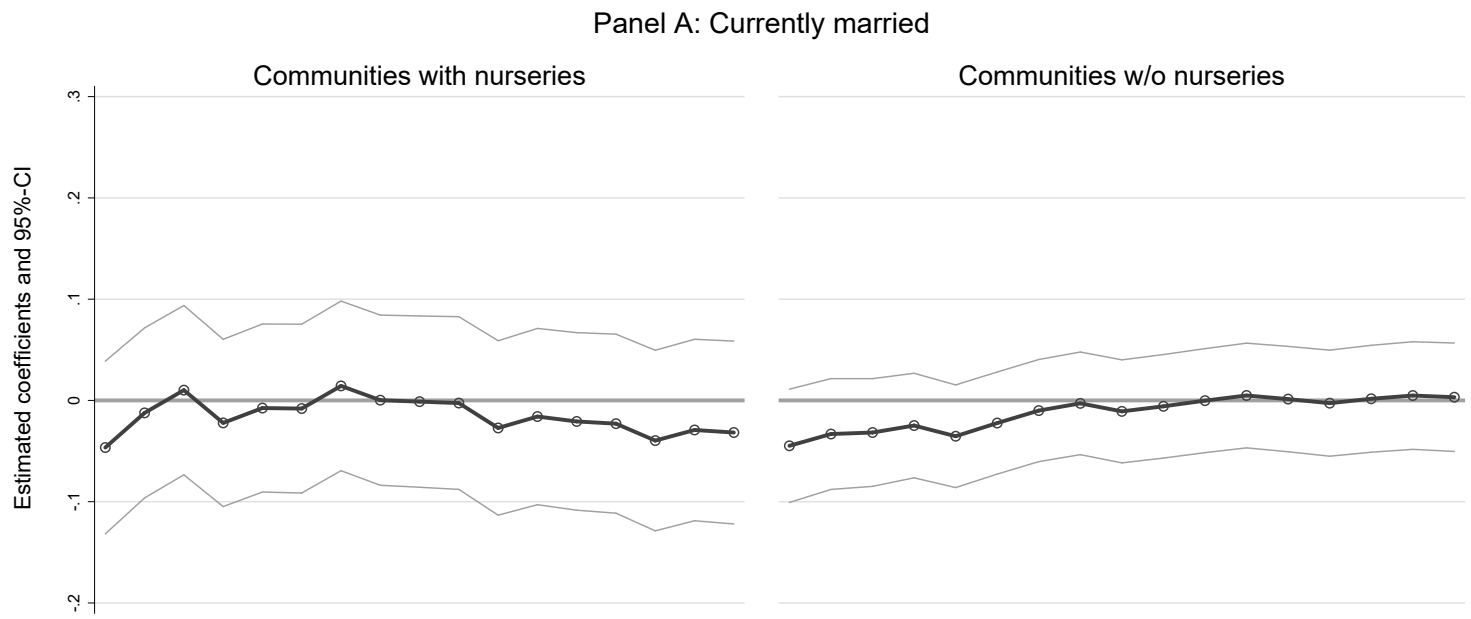

Panel B: Conditional on being married at birth
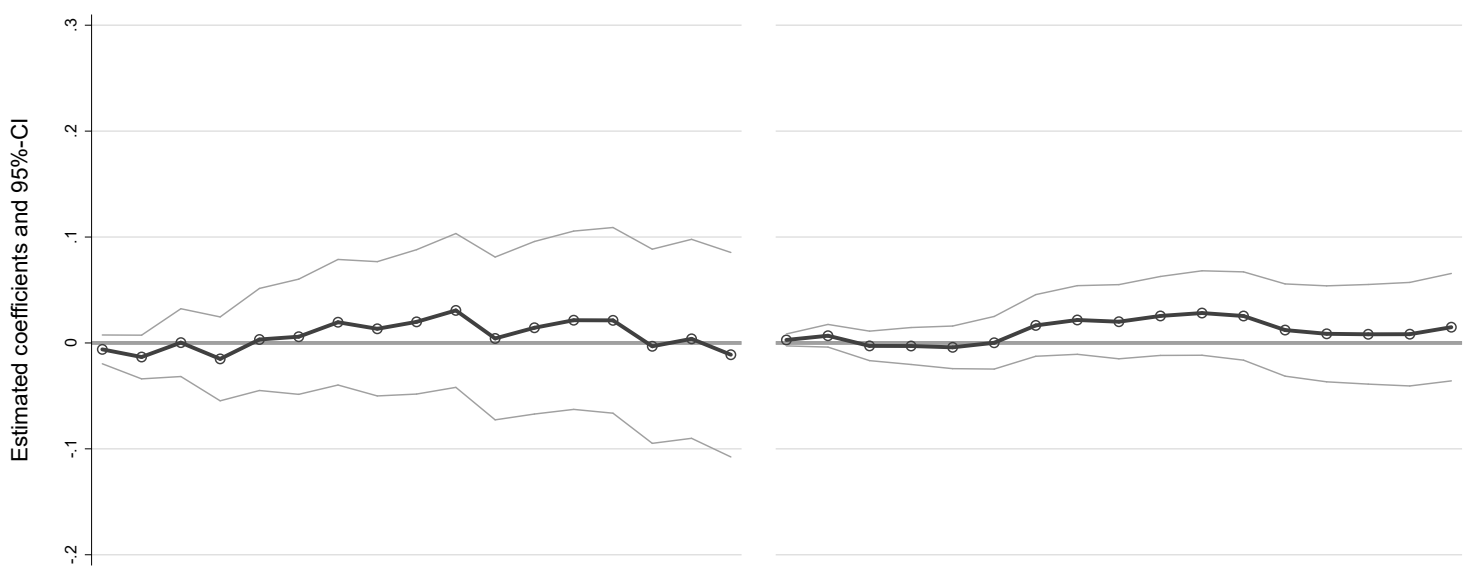

Panel C: Conditional on not being married at birth
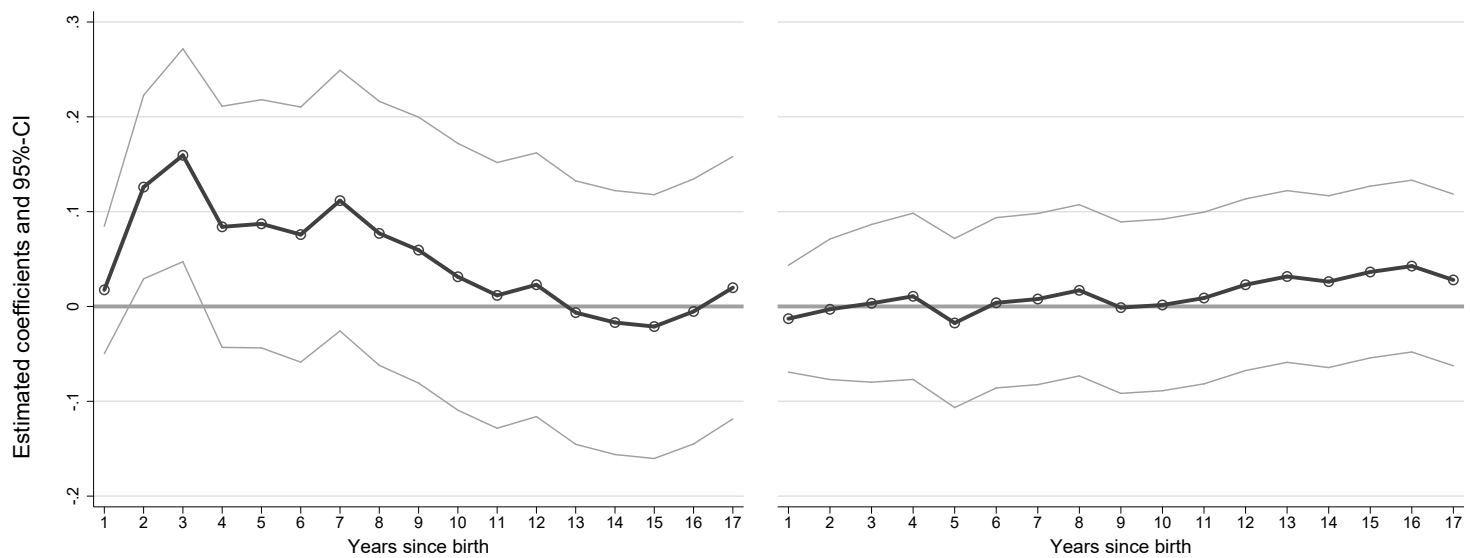

Notes: These figures show the estimated coefficients and 95\% confidence intervals from separate 2SLS regressions with years on PL instrumented by the assignment to the reform. Family status is measured as the probability to be married in each year of the child's life for the full sample of mothers (Panel A), for the sample of mothers who have been married at birth (Panel B), and for the sample of mothers who have not been married at birth (Panel C). See Appendix Tables A.15, A.16 and A.17 for full regression output and further information. 
Figure 10: Child outcomes in communities with and w/o nursery

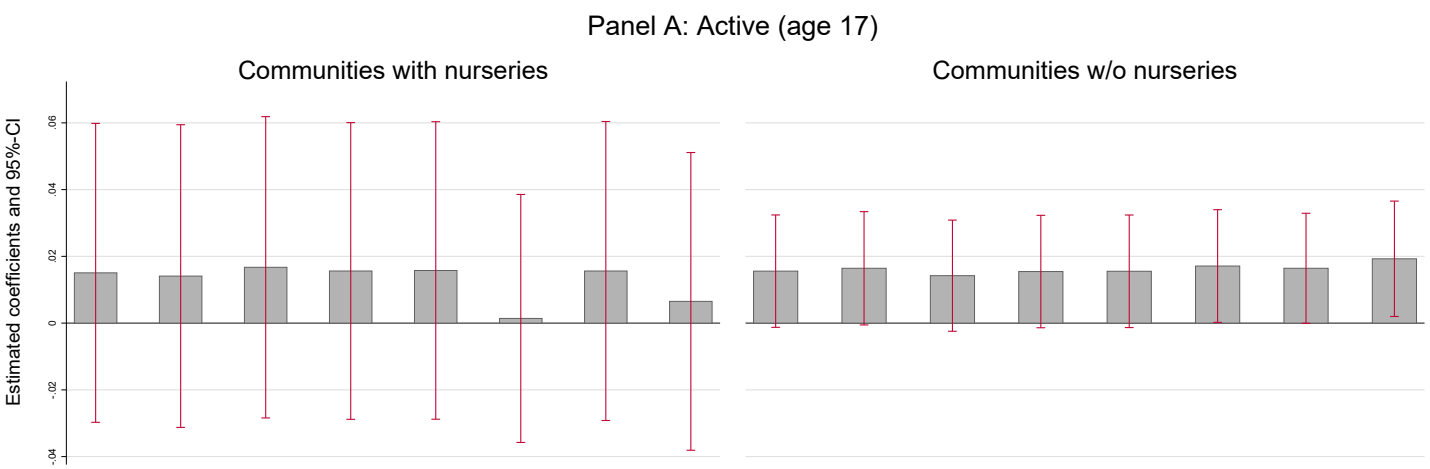

Panel B: Active (age 23)

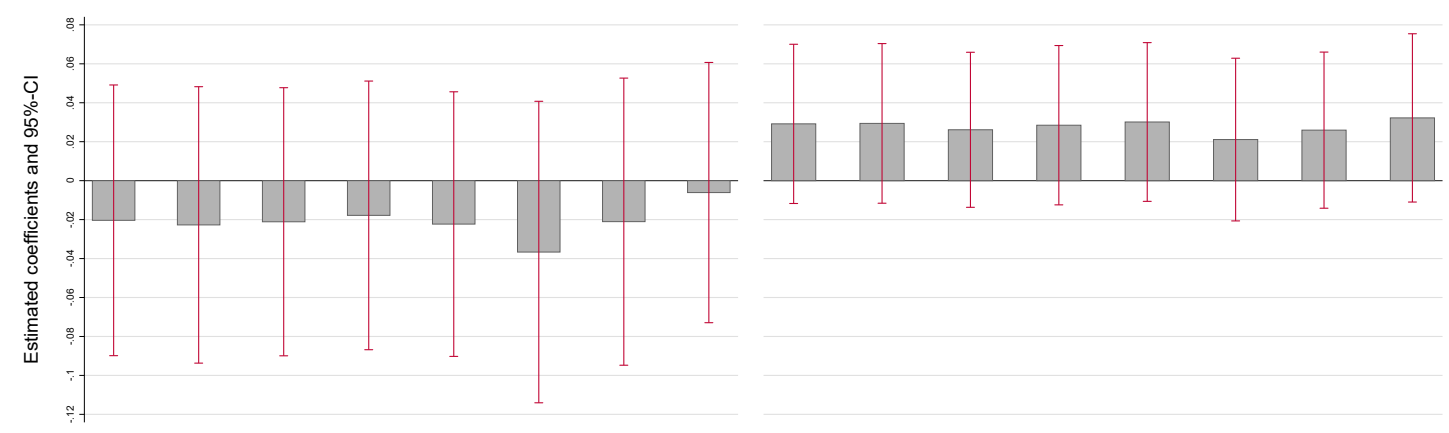

Panel C: Active (age 17-23)

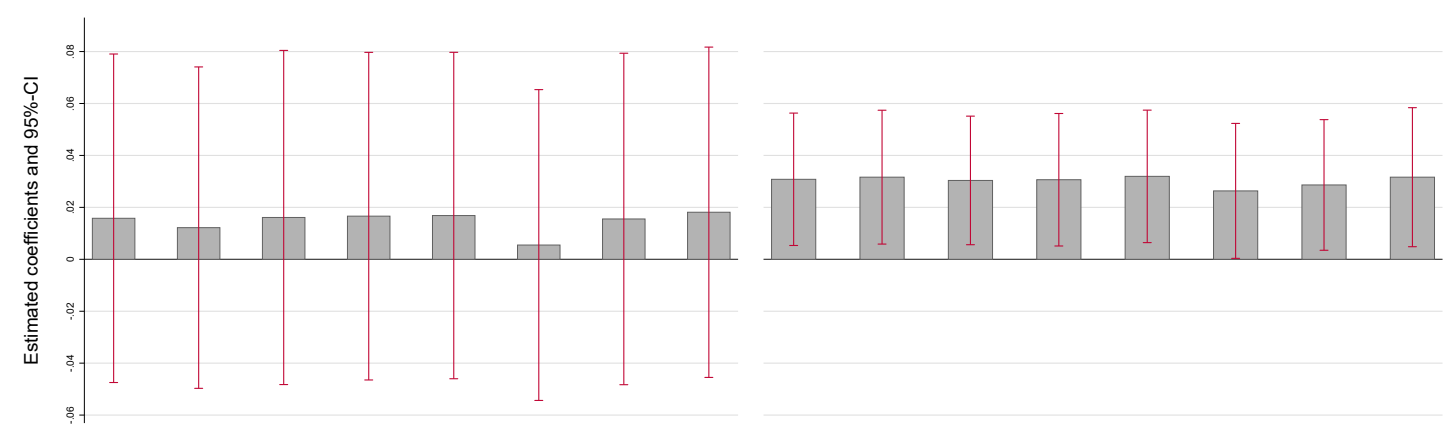

Panel D: Non-disabled

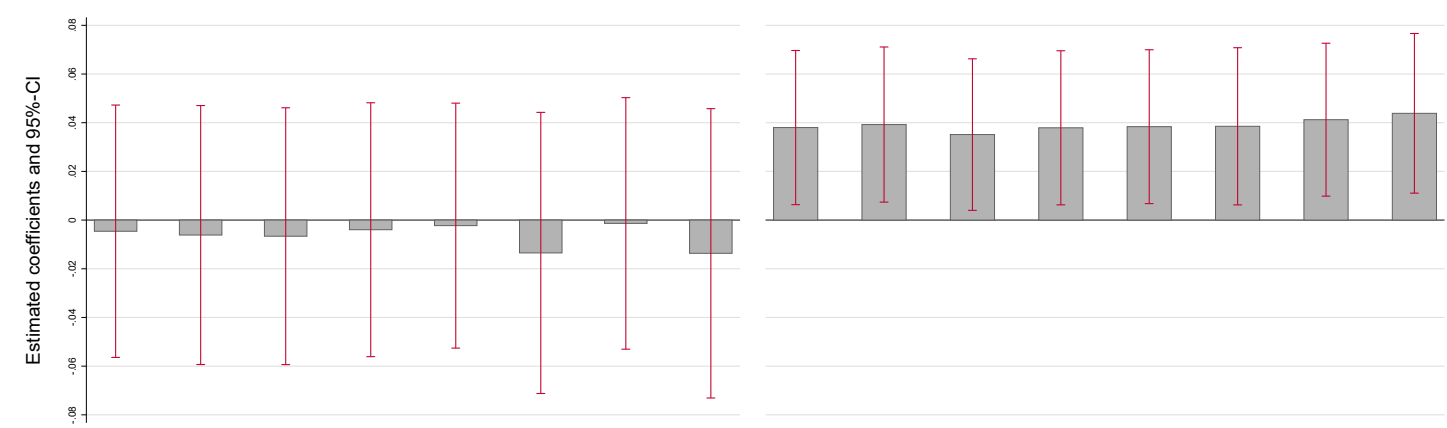

Panel E: Fit for military (boys)

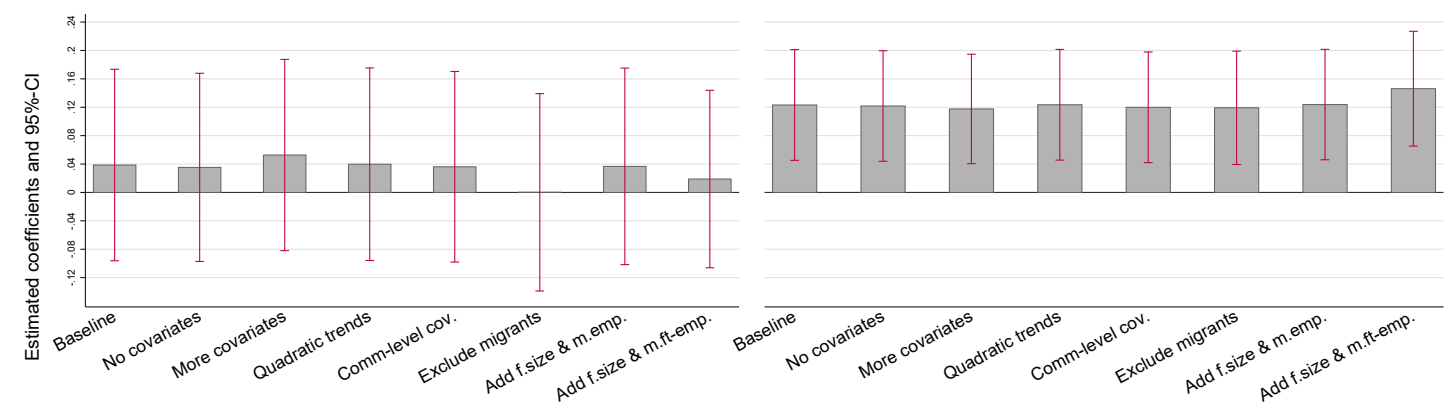


Table 1: Availability of kindergartens and nurseries, 1988-1995

\begin{tabular}{|c|c|c|c|c|c|c|c|c|}
\hline Year & 1988 & 1989 & 1990 & 1991 & 1992 & 1993 & 1994 & 1995 \\
\hline \multicolumn{9}{|l|}{ Kindergarten available: } \\
\hline Percent of communities & 78.6 & 81.0 & 81.5 & 85.2 & 84.1 & 85.2 & 85.6 & 86.7 \\
\hline Percent of total population & 94.6 & 95.7 & 95.8 & 95.9 & 96.5 & 96.9 & 97.0 & 97.5 \\
\hline \multicolumn{9}{|l|}{ Nursery available: } \\
\hline Percent of communities & 1.6 & 1.6 & 1.8 & 1.8 & 2.2 & 2.4 & 2.7 & 2.9 \\
\hline Percent of total population & 33.2 & 33.1 & 33.4 & 33.3 & 33.9 & 34.5 & 34.7 & 35.1 \\
\hline
\end{tabular}

Notes: Own calculations based on data from Statistics Austria. 


\begin{tabular}{|c|c|c|c|c|}
\hline & & \multicolumn{3}{|c|}{ Communities } \\
\hline & & All & & $\begin{array}{c}\mathbf{w} / \mathbf{o} \\
\text { nursery }\end{array}$ \\
\hline Data source $^{a}$ & $N$ & Mean & Mean & Mean \\
\hline
\end{tabular}

Child:

LABOR MARKET OUTCOMES

Active (age 17)

In education (age 17)

Active (age 23)

In education (age 23)

Employed (age 23)

Log wage (age 23)

Active (age 17-23)

Always active (age 17-23)

HeAlth OUtComes

Non-disabled

Fit for military (boys)

\section{Mother:}

Employed $(t=10)$

Full-time employed $(t=10)$

Binary indicator equal to one if child is active at the age of 17 . The child is considered as active if s/he is either in education (school, apprenticeship, or university), employed (excl. marginal employment ${ }^{a}$ ), on maternity/PL or in military or alternative civilian service. Inactive children are unemployed, marginally employed, disabl

or in other kinds of inactive social insurance periods.

Binary indicator equal to one if child is active at the age of 23 .

Binary indicator equal to one if child is in education at the age of 23

Binary indicator equal to one if child is employed at the age of 23 .

This variable captures the daily log wage at the age of 23 .

This variable captures the share of active spells between 17 and 23 years of age.

Binary indicator equal to one if child is always active between 17 and 23 years of age.

Binary indicator equal to one if child has never had a disability of at least 50 percent (age 7-17) and was never permanently unable to work (age 18-23).

Binary indicator equal to one if male child is fit for military.

Binary indicator equal to one if the mother is employed $t$ years after parity one (measured

Binary indicator equal to one if the mother is full-time employed $t$ years after parity one. We define a mothers as full-time employed, if she earns at least $75 \%$ of her pre-birth earnings.

Family:

Further child $(t=10)$

Number of children $(t=10)$

Binary indicator equal to one if the mother gave birth to a further child $t$ years after parity one (measured on the child's bithday each year).

This variable captures the number of children $t$ years after parity one (measured on the child's birthday each year).

Currently married $(t=10)$ on January 1 , in each year).

$\begin{array}{llll}\text { ASSD/Ministry } \quad 8,508 & 0.980 & 0.972\end{array}$

0.984

$\begin{array}{lllll}\text { ASSD/Ministry } & 8,508 & 0.976 & 0.967 & 0.980\end{array}$

$\begin{array}{lllll}\text { ASSD/Ministry } & 8,338 & 0.897 & 0.852 & 0.915\end{array}$

$\begin{array}{lllll}\text { ASSD/Ministry } & 8,338 & 0.258 & 0.313 & 0.236\end{array}$

$\begin{array}{llllll}\text { ASSD/Ministry } & 8,338 & 0.605 & 0.504 & 0.646\end{array}$

$\begin{array}{lllll}\text { ASSD/Ministry } & 4,894 & 4.253 & 4.173 & 4.277\end{array}$

$\begin{array}{lllll}\text { ASSD/Ministry } & 8,775 & 0.867 & 0.834 & 0.880\end{array}$

$\begin{array}{lllll}\text { ASSD/Ministry } & 8,775 & 0.494 & 0.441 & 0.516\end{array}$

$\begin{array}{ccccc}\text { Ministry } & 8,310 & 0.953 & 0.945 & 0.956 \\ \text { ASSD } & 4,515 & 0.782 & 0.751 & 0.795 \\ & & & & \\ \text { ASSD } & 8,775 & 0.587 & 0.642 & 0.563 \\ \text { ASSD } & 8,332 & 0.369 & 0.459 & 0.332 \\ & & & & \\ \text { ABR } & 8,775 & 0.682 & 0.586 & 0.722 \\ \text { ABR } & 8,775 & 1.882 & 1.750 & 1.938 \\ \text { AMR/ADR } & 8,775 & 0.737 & 0.696 & 0.754\end{array}$

Notes: ASSD = Austrian Social Security Database, Ministry $=$ Database of the Ministry of Labour, Social Affairs and Consumer Protection, ABR $=$ Austrian Birth Register, AMR $=$ Austrian Marriage Register, ADR = Austrian Divorce Register. ${ }^{a}$ This type of employment contract is for jobs with a low number of working hours and low pay and covers only accident insurance. 
Table 3: Testing for baseline differences between not-assigned and assigned families

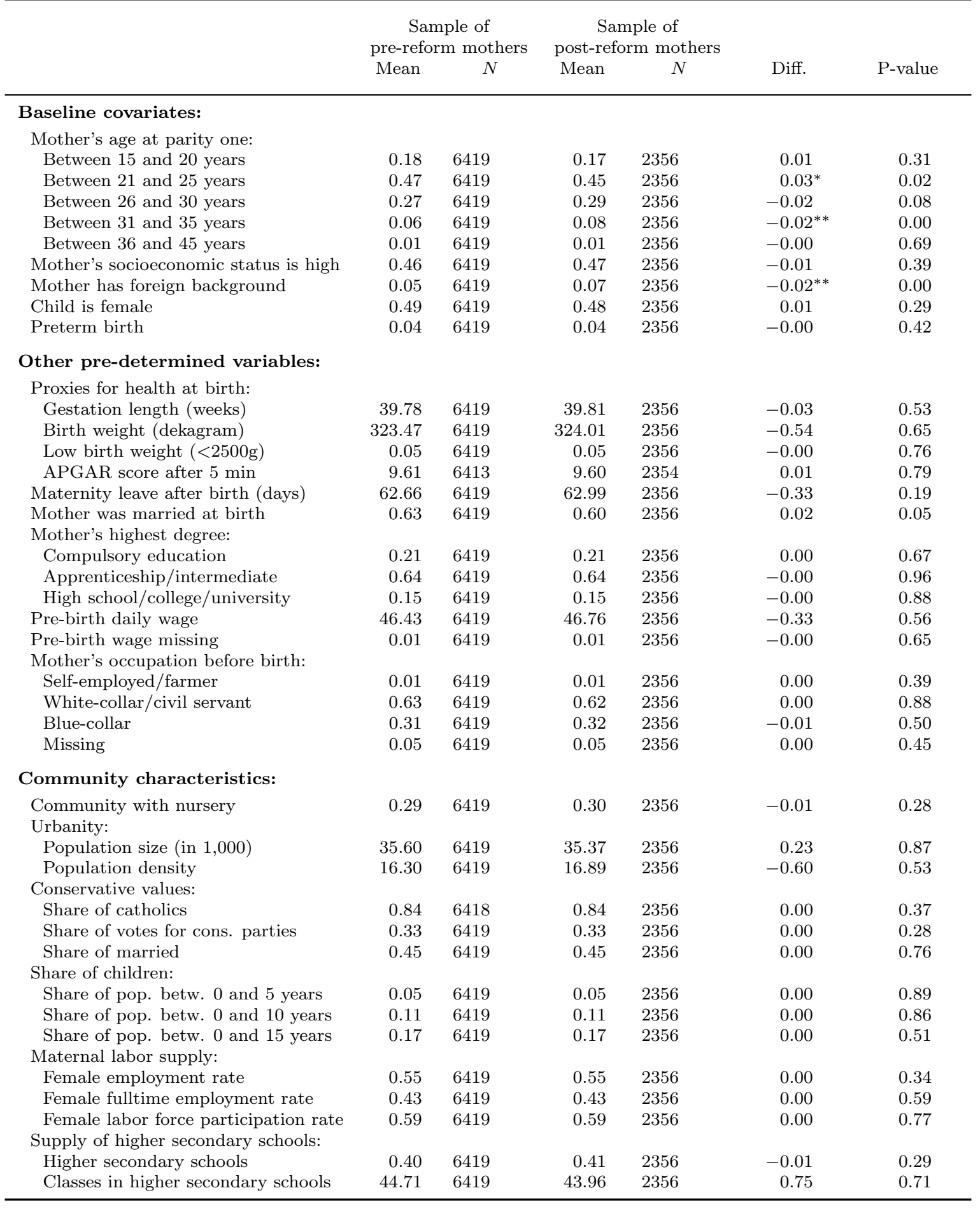

Notes: This table summarizes sample means and the number of observations of the samples of not-assigned and assigned mothers, the difference in the two sample means, and the p-value resulting from a t-test on the equality of means (for our estimation sample). Not-assigned or pre-reform mothers are those whose child is born in June/July 1989 or in June 1990, while assigned or post-reform mothers' children are born in July 1990. We exclude children born \pm 5 days around the cutoff. $*, * *$ and $* * *$ indicate statistical significance at the 10-percent, 5-percent and 1-percent level. 
Table 4: Average child outcomes (Table 4)

\begin{tabular}{|c|c|c|c|c|c|c|c|c|}
\hline & $\begin{array}{c}(1) \\
\text { Baseline }\end{array}$ & $\begin{array}{c}(2) \\
\text { No } \\
\text { covariates }\end{array}$ & $\begin{array}{c}(3) \\
\text { More } \\
\text { covariates }\end{array}$ & $\begin{array}{c}(4) \\
\text { Community } \\
\text { covariates }\end{array}$ & $\begin{array}{c}(5) \\
\text { Quadratic } \\
\text { trends }\end{array}$ & $\begin{array}{c}(6) \\
\text { Exclude } \\
\text { migrants }\end{array}$ & $\begin{array}{c}(7) \\
\text { No } \\
\text { donut }\end{array}$ & $\begin{array}{c}(8) \\
\text { Bandwidth } \\
61 \text { days }\end{array}$ \\
\hline \multicolumn{9}{|l|}{ Labor market outcomes } \\
\hline Active (age 17) & $\begin{array}{c}0.015 \\
(0.009)\end{array}$ & $\begin{array}{c}0.015 \\
(0.009)\end{array}$ & $\begin{array}{c}0.014 \\
(0.009)\end{array}$ & $\begin{array}{c}0.016^{*} \\
(0.009)\end{array}$ & $\begin{array}{c}0.015 \\
(0.009)\end{array}$ & $\begin{array}{c}0.012 \\
(0.009)\end{array}$ & $\begin{array}{c}0.012 \\
(0.008)\end{array}$ & $\begin{array}{c}0.008 \\
(0.006)\end{array}$ \\
\hline In education (age 17) & $\begin{array}{c}0.015 \\
(0.011)\end{array}$ & $\begin{array}{c}0.015 \\
(0.011)\end{array}$ & $\begin{array}{c}0.015 \\
(0.010)\end{array}$ & $\begin{array}{c}0.016 \\
(0.010)\end{array}$ & $\begin{array}{c}0.015 \\
(0.010)\end{array}$ & $\begin{array}{c}0.012 \\
(0.010)\end{array}$ & $\begin{array}{c}0.013 \\
(0.009)\end{array}$ & $\begin{array}{c}0.005 \\
(0.007)\end{array}$ \\
\hline Active (age 23) & $\begin{array}{c}0.013 \\
(0.018)\end{array}$ & $\begin{array}{c}0.011 \\
(0.018)\end{array}$ & $\begin{array}{c}0.014 \\
(0.017)\end{array}$ & $\begin{array}{c}0.017 \\
(0.018)\end{array}$ & $\begin{array}{c}0.014 \\
(0.018)\end{array}$ & $\begin{array}{c}0.004 \\
(0.019)\end{array}$ & $\begin{array}{c}0.006 \\
(0.017)\end{array}$ & $\begin{array}{c}0.008 \\
(0.012)\end{array}$ \\
\hline In education (age 23) & $\begin{array}{c}0.006 \\
(0.026)\end{array}$ & $\begin{array}{c}0.013 \\
(0.027)\end{array}$ & $\begin{array}{l}-0.000 \\
(0.025)\end{array}$ & $\begin{array}{c}0.005 \\
(0.026)\end{array}$ & $\begin{array}{c}0.007 \\
(0.026)\end{array}$ & $\begin{array}{c}-0.001 \\
(0.027)\end{array}$ & $\begin{array}{c}0.024 \\
(0.024)\end{array}$ & $\begin{array}{c}0.013 \\
(0.018)\end{array}$ \\
\hline Employed (age 23) & $\begin{array}{c}0.012 \\
(0.029)\end{array}$ & $\begin{array}{c}0.003 \\
(0.030)\end{array}$ & $\begin{array}{c}0.019 \\
(0.027)\end{array}$ & $\begin{array}{c}0.018 \\
(0.029)\end{array}$ & $\begin{array}{c}0.012 \\
(0.029)\end{array}$ & $\begin{array}{c}0.012 \\
(0.031)\end{array}$ & $\begin{array}{c}-0.011 \\
(0.027)\end{array}$ & $\begin{array}{c}-0.009 \\
(0.020)\end{array}$ \\
\hline Log wage (age 23) & $\begin{array}{c}-0.006 \\
(0.028)\end{array}$ & $\begin{array}{c}-0.010 \\
(0.031)\end{array}$ & $\begin{array}{c}-0.004 \\
(0.029)\end{array}$ & $\begin{array}{c}0.001 \\
(0.029)\end{array}$ & $\begin{array}{c}-0.004 \\
(0.028)\end{array}$ & $\begin{array}{c}-0.010 \\
(0.029)\end{array}$ & $\begin{array}{c}-0.018 \\
(0.026)\end{array}$ & $\begin{array}{c}0.006 \\
(0.019)\end{array}$ \\
\hline Active (age 17-23) & $\begin{array}{c}0.025^{*} \\
(0.013)\end{array}$ & $\begin{array}{c}0.023^{*} \\
(0.013)\end{array}$ & $\begin{array}{l}0.027^{* *} \\
(0.013)\end{array}$ & $\begin{array}{l}0.029^{* *} \\
(0.013)\end{array}$ & $\begin{array}{c}0.025^{*} \\
(0.013)\end{array}$ & $\begin{array}{c}0.019 \\
(0.013)\end{array}$ & $\begin{array}{c}0.024^{*} \\
(0.013)\end{array}$ & $\begin{array}{c}0.014^{*} \\
(0.009)\end{array}$ \\
\hline Always active (age 17-23) & $\begin{array}{c}0.013 \\
(0.031)\end{array}$ & $\begin{array}{c}0.010 \\
(0.031)\end{array}$ & $\begin{array}{c}0.015 \\
(0.031)\end{array}$ & $\begin{array}{c}0.018 \\
(0.031)\end{array}$ & $\begin{array}{c}0.012 \\
(0.031)\end{array}$ & $\begin{array}{c}-0.005 \\
(0.031)\end{array}$ & $\begin{array}{c}0.014 \\
(0.027)\end{array}$ & $\begin{array}{c}0.011 \\
(0.020)\end{array}$ \\
\hline \multicolumn{9}{|l|}{ Health outcomes } \\
\hline Non-disabled & $\begin{array}{c}0.025^{*} \\
(0.014)\end{array}$ & $\begin{array}{c}0.025^{*} \\
(0.014)\end{array}$ & $\begin{array}{c}0.024^{*} \\
(0.014)\end{array}$ & $\begin{array}{c}0.026^{*} \\
(0.014)\end{array}$ & $\begin{array}{c}0.025^{*} \\
(0.014)\end{array}$ & $\begin{array}{c}0.023 \\
(0.015)\end{array}$ & $\begin{array}{c}0.023^{*} \\
(0.012)\end{array}$ & $\begin{array}{c}0.012 \\
(0.009)\end{array}$ \\
\hline Fit for military (boys) & $\begin{array}{l}0.099^{* * *} \\
(0.034)\end{array}$ & $\begin{array}{l}0.096^{* * *} \\
(0.034)\end{array}$ & $\begin{array}{l}0.099^{* * *} \\
(0.034)\end{array}$ & $\begin{array}{l}0.098^{* * *} \\
(0.034)\end{array}$ & $\begin{array}{l}0.099^{* * *} \\
(0.034)\end{array}$ & $\begin{array}{l}0.085^{* *} \\
(0.035)\end{array}$ & $\begin{array}{c}0.063^{*} \\
(0.036)\end{array}$ & $\begin{array}{c}0.059^{* *} \\
(0.025)\end{array}$ \\
\hline
\end{tabular}

Notes: Each coefficient represents a separate regression. Coefficients are 2SLS estimates, with years on PL instrumented by the assignment to the reform. We use local linear regressions including triangular weights and separate trends on each side of the discontinuity. In the baseline specification (1) we use a bandwidth of 30 days and linear trends in the running variable, exclude children born \pm 5 days around the cutoff date, and control for a vector of pre-determined variables $\mathbf{x}$ (child's sex, low maternal SES, maternal age groups, whether the mother was born abroad, and whether the child was a pre-term birth). Column (2) does not include $\mathbf{x}$. Column (3) includes additional pre-determined controls for maternal daily real wage (mean over last 2 years before child birth), maternal occupation (white-collar/civil servant, blue-collar, self-employed/farmer), whether the mother was married, maternal education (6 indicators), maternal religious denomination (5 indicators), province (8 indicators), and whether the child had low birth weight. Column (4) includes the following community-level covariates: population size, population density, share of catholics, share of votes for conservative parties, share of married, share of pop. betw. 0 and 5 years, share of pop. betw. 0 and 15 years, female employment rate, female fulltime employment rate, availability of a higher secondary school and number of classes in higher secondary schools. Column (5) includes quadratic trends in the running variable. Column (6) drops all foreign-born mothers from the sample. Column (7) includes children born \pm 5 days around the cutoff. Column (8) is based on a bandwidth of 61 days before and after the cutoff (excluding children born \pm 5 days around the cutoff date). Standard errors (shown in parentheses) are clustered at the community of 61 days before and after the cutoff (excluding children born \pm 5 days around the cutoff date). Stand 
Table 5: Differences between communities with and w/o nursery

\begin{tabular}{|c|c|c|c|c|}
\hline & $\begin{array}{l}\text { Communities } \\
\text { with nursery }\end{array}$ & $\begin{array}{l}\text { Communities } \\
\text { w/o nursery }\end{array}$ & Diff. & P-value \\
\hline \multicolumn{5}{|l|}{ Baseline covariates: } \\
\hline Mother's age at birth & 25.20 & 23.95 & $1.24^{* *}$ & 0.00 \\
\hline Mother's socioeconomic status is high & 0.52 & 0.44 & $0.08^{* *}$ & 0.00 \\
\hline Mother has foreign background & 0.11 & 0.03 & $0.08^{* *}$ & 0.00 \\
\hline Child is female & 0.49 & 0.48 & 0.01 & 0.59 \\
\hline Preterm birth & 0.04 & 0.04 & 0.00 & 0.89 \\
\hline \multicolumn{5}{|l|}{ Other pre-determined variables: } \\
\hline \multicolumn{5}{|l|}{ Proxies for health at birth: } \\
\hline Gestation length (weeks) & 39.80 & 39.79 & 0.01 & 0.79 \\
\hline Birth weight (dekagram) & 323.97 & 323.47 & 0.50 & 0.66 \\
\hline Low birth weight $(<2500 \mathrm{~g})$ & 0.05 & 0.05 & -0.00 & 0.63 \\
\hline APGAR score after 5 min & 9.72 & 9.56 & $0.16^{* *}$ & 0.00 \\
\hline Maternity leave after birth (days) & 62.68 & 62.78 & -0.09 & 0.69 \\
\hline Mother was married at birth & 0.68 & 0.60 & $0.08^{* *}$ & 0.00 \\
\hline \multicolumn{5}{|l|}{ Mother's highest degree: } \\
\hline Compulsory education & 0.19 & 0.22 & $-0.03^{* *}$ & 0.00 \\
\hline Apprenticeship/intermediate & 0.57 & 0.67 & $-0.10^{* *}$ & 0.00 \\
\hline High school/college/university & 0.23 & 0.11 & $0.12^{* *}$ & 0.00 \\
\hline Mean pre-birth daily real wage & 48.68 & 45.62 & $3.06^{* *}$ & 0.00 \\
\hline \multicolumn{5}{|l|}{ Mother's occupation before birth: } \\
\hline Self-employed/farmer & 0.01 & 0.01 & -0.00 & 0.64 \\
\hline White-collar/civil servant & 0.70 & 0.60 & $0.10^{* *}$ & 0.00 \\
\hline Blue-collar & 0.22 & 0.35 & $-0.13^{* *}$ & 0.00 \\
\hline Missing & 0.07 & 0.04 & $0.03^{* *}$ & 0.00 \\
\hline \multicolumn{5}{|l|}{ Community characteristics: } \\
\hline \multicolumn{5}{|l|}{ Urbanity: } \\
\hline Population size (in 1,000 ) & 106.92 & 5.64 & $101.28^{* *}$ & 0.00 \\
\hline Population density & 50.26 & 2.30 & $47.96^{* *}$ & 0.00 \\
\hline \multicolumn{5}{|l|}{ Conservative values: } \\
\hline Share of catholics & 0.69 & 0.91 & $-0.21^{* *}$ & 0.00 \\
\hline Share of votes for cons. parties & 0.22 & 0.37 & $-0.15^{* *}$ & 0.00 \\
\hline Share of married & 0.43 & 0.46 & $-0.03^{* *}$ & 0.00 \\
\hline \multicolumn{5}{|l|}{ Share of children: } \\
\hline Share of pop. betw. 0 and 5 years & 0.04 & 0.05 & $-0.01^{* *}$ & 0.00 \\
\hline Share of pop. betw. 0 and 10 years & 0.09 & 0.12 & $-0.03^{* *}$ & 0.00 \\
\hline Share of pop. betw. 0 and 15 years & 0.13 & 0.18 & $-0.05^{* *}$ & 0.00 \\
\hline \multicolumn{5}{|l|}{ Maternal labor supply: } \\
\hline Female employment rate & 0.64 & 0.52 & $0.12^{* *}$ & 0.00 \\
\hline Female fulltime employment rate & 0.50 & 0.40 & $0.10^{* *}$ & 0.00 \\
\hline Female labor force participation rate & 0.69 & 0.55 & $0.14^{* *}$ & 0.00 \\
\hline \multicolumn{5}{|l|}{ Supply of higher secondary schools: } \\
\hline Any school & 0.98 & 0.16 & $0.82^{* *}$ & 0.00 \\
\hline Number of classes & 137.81 & 5.43 & $132.38^{* *}$ & 0.00 \\
\hline
\end{tabular}

Notes: This table summarizes sample means of the samples of mothers who gave birth in communities with a nursery and mothers who gave birth in communities without a nursery, the difference in the two sample means, and the p-value resulting from a $t$ test on the equality of means (for our estimation sample). ${ }^{*}$ and ${ }^{* *}$ indicate statistical significance at the 5-percent and 1-percent level. 
Table 6: Child outcomes by availability of nursery

\begin{tabular}{|c|c|c|c|}
\hline & $\begin{array}{l}\text { Communities } \\
\text { with nursery }\end{array}$ & $\begin{array}{l}\text { Communities } \\
\text { w/o nursery }\end{array}$ & $\begin{array}{r}\mathrm{P} \text {-value } \\
\Delta^{c}\end{array}$ \\
\hline \multicolumn{4}{|l|}{ Labor market outcomes } \\
\hline Active (age 17) & $\begin{array}{c}0.015 \\
(0.023)\end{array}$ & $\begin{array}{c}0.016^{*} \\
(0.009)\end{array}$ & 0.983 \\
\hline In education (age 17) & $\begin{array}{l}0.008 \\
(0.026)\end{array}$ & $\begin{array}{l}0.019 * * \\
(0.009)\end{array}$ & 0.712 \\
\hline Active (age 23) & $\begin{array}{c}-0.020 \\
(0.035)\end{array}$ & $\begin{array}{c}0.029 \\
(0.021)\end{array}$ & 0.227 \\
\hline In education (age 23) & $\begin{array}{c}-0.000 \\
(0.048)\end{array}$ & $\begin{array}{c}0.004 \\
(0.030)\end{array}$ & 0.947 \\
\hline Employed (age 23) & $\begin{array}{c}-0.006 \\
(0.050)\end{array}$ & $\begin{array}{l}0.026 \\
(0.035)\end{array}$ & 0.602 \\
\hline Log wage (age 23) & $\begin{array}{c}-0.035 \\
(0.063)\end{array}$ & $\begin{array}{c}0.006 \\
(0.032)\end{array}$ & 0.563 \\
\hline Active (age 17-23) & $\begin{array}{c}0.016 \\
(0.032)\end{array}$ & $\begin{array}{l}0.031^{* *} \\
(0.013)\end{array}$ & 0.666 \\
\hline Always active (age 17-23) & $\begin{array}{c}-0.058 \\
(0.062)\end{array}$ & $\begin{array}{c}0.047 \\
(0.034)\end{array}$ & 0.138 \\
\hline \multicolumn{4}{|l|}{ Health outcomes } \\
\hline Non-disabled & $\begin{array}{c}-0.005 \\
(0.026)\end{array}$ & $\begin{array}{l}0.038^{* *} \\
(0.016)\end{array}$ & 0.170 \\
\hline Fit for military (boys) & $\begin{array}{c}0.039 \\
(0.069)\end{array}$ & $\begin{array}{l}0.123^{* * *} \\
(0.040)\end{array}$ & 0.286 \\
\hline
\end{tabular}

Notes: Each row represents a separate regression. Estimation results are based on fully interacted models. Coefficients are 2SLS estimates, with years on PL instrumented by the assignment to the reform (both interacted with indicators for mothers who lived in communities with and w/o nursery). We use local linear regressions including triangular weights and separate linear trends on each side of the discontinuity. We use a bandwidth of 30 days, exclude children born \pm 5 days around the cutoff date, and control for the child's sex, low maternal SES, maternal age groups, whether the mother was born abroad, and whether the child was a pre-term birth. Standard errors (shown in parentheses) are clustered at the community level. *,** and *** indicate statistical significance at the 10-percent, 5-percent and 1-percent level. ${ }^{a}$ The mother lived in a community with a nursery. ${ }^{b}$ The mother lived in a community without a nursery. ${ }^{c}$ Prob $>\mathrm{F}($ chi2) of diff. in coefficients between communities with and w/o nursery. 
Table 7: Sensitivity: Child outcomes by availability of nursery

\begin{tabular}{|c|c|c|c|c|c|c|c|c|c|c|c|c|}
\hline & \multicolumn{6}{|c|}{ Communities with nursery } & \multicolumn{6}{|c|}{ Communities w/o nursery } \\
\hline & $\begin{array}{c}(1) \\
\text { Baseline }\end{array}$ & $\begin{array}{c}(2) \\
\text { No } \\
\text { covariates }\end{array}$ & $\begin{array}{c}\text { (3) } \\
\text { More } \\
\text { covariates }\end{array}$ & $\begin{array}{c}(4) \\
\text { Community } \\
\text { covariates }\end{array}$ & $\begin{array}{c}(5) \\
\text { Quadratic } \\
\text { trends }\end{array}$ & $\begin{array}{c}(6) \\
\text { Exclude } \\
\text { migrants }\end{array}$ & $\begin{array}{c}(1) \\
\text { Baseline }\end{array}$ & $\begin{array}{c}(2) \\
\text { No } \\
\text { covariates }\end{array}$ & $\begin{array}{c}\text { (3) } \\
\text { More } \\
\text { covariates }\end{array}$ & $\begin{array}{c}(4) \\
\text { Community } \\
\text { covariates }\end{array}$ & $\begin{array}{c}(5) \\
\text { Quadratic } \\
\text { trends }\end{array}$ & $\begin{array}{l}(6) \\
\text { Exclude } \\
\text { migrants }\end{array}$ \\
\hline Active (age 17) & $\begin{array}{c}0.015 \\
(0.023)\end{array}$ & $\begin{array}{c}0.014 \\
(0.023)\end{array}$ & $\begin{array}{c}0.017 \\
(0.023)\end{array}$ & $\begin{array}{c}0.016 \\
(0.023)\end{array}$ & $\begin{array}{l}0.016 \\
(0.023)\end{array}$ & $\begin{array}{c}0.001 \\
(0.019)\end{array}$ & $\begin{array}{c}0.016^{*} \\
(0.009)\end{array}$ & $\begin{array}{c}0.016^{*} \\
(0.009)\end{array}$ & $\begin{array}{c}0.014^{*} \\
(0.008)\end{array}$ & $\begin{array}{c}0.016^{*} \\
(0.009)\end{array}$ & $\begin{array}{c}0.015^{*} \\
(0.009)\end{array}$ & $\begin{array}{l}0.017^{* *} \\
(0.009)\end{array}$ \\
\hline Active (age 23) & $\begin{array}{c}-0.020 \\
(0.035)\end{array}$ & $\begin{array}{c}-0.023 \\
(0.036)\end{array}$ & $\begin{array}{c}-0.021 \\
(0.035)\end{array}$ & $\begin{array}{c}-0.022 \\
(0.035)\end{array}$ & $\begin{array}{c}-0.018 \\
(0.035)\end{array}$ & $\begin{array}{c}-0.037 \\
(0.039)\end{array}$ & $\begin{array}{c}0.029 \\
(0.021)\end{array}$ & $\begin{array}{c}0.029 \\
(0.021)\end{array}$ & $\begin{array}{c}0.026 \\
(0.020)\end{array}$ & $\begin{array}{c}0.030 \\
(0.021)\end{array}$ & $\begin{array}{c}0.028 \\
(0.021)\end{array}$ & $\begin{array}{c}0.021 \\
(0.021)\end{array}$ \\
\hline Active (age 17-23) & $\begin{array}{c}0.016 \\
(0.032)\end{array}$ & $\begin{array}{c}0.012 \\
(0.032)\end{array}$ & $\begin{array}{l}0.016 \\
(0.033)\end{array}$ & $\begin{array}{l}0.017 \\
(0.032)\end{array}$ & $\begin{array}{c}0.017 \\
(0.032)\end{array}$ & $\begin{array}{l}0.005 \\
(0.031)\end{array}$ & $\begin{array}{l}0.031 * * \\
(0.013)\end{array}$ & $\begin{array}{l}0.032 * * \\
(0.013)\end{array}$ & $\begin{array}{l}0.030 * * \\
(0.013)\end{array}$ & $\begin{array}{l}0.032^{* *} \\
(0.013)\end{array}$ & $\begin{array}{l}0.031 * * \\
(0.013)\end{array}$ & $\begin{array}{l}0.026^{* *} \\
(0.013)\end{array}$ \\
\hline Non-disabled & $\begin{array}{c}-0.005 \\
(0.026)\end{array}$ & $\begin{array}{c}-0.006 \\
(0.027)\end{array}$ & $\begin{array}{c}-0.007 \\
(0.027)\end{array}$ & $\begin{array}{c}-0.002 \\
(0.026)\end{array}$ & $\begin{array}{c}-0.004 \\
(0.027)\end{array}$ & $\begin{array}{c}-0.013 \\
(0.029)\end{array}$ & $\begin{array}{l}0.038^{* *} \\
(0.016)\end{array}$ & $\begin{array}{l}0.039 * * \\
(0.016)\end{array}$ & $\begin{array}{l}0.035 * * \\
(0.016)\end{array}$ & $\begin{array}{l}0.038^{* *} \\
(0.016)\end{array}$ & $\begin{array}{l}0.038 * * \\
(0.016)\end{array}$ & $\begin{array}{l}0.039 * * \\
(0.016)\end{array}$ \\
\hline Fit for military (boys) & $\begin{array}{c}0.039 \\
(0.069)\end{array}$ & $\begin{array}{c}0.035 \\
(0.068)\end{array}$ & $\begin{array}{c}0.053 \\
(0.069)\end{array}$ & $\begin{array}{c}0.036 \\
(0.069)\end{array}$ & $\begin{array}{c}0.040 \\
(0.069)\end{array}$ & $\begin{array}{l}0.000 \\
(0.071)\end{array}$ & $\begin{array}{l}0.123^{* * *} \\
(0.040)\end{array}$ & $\begin{array}{l}0.122^{* * *} \\
(0.040)\end{array}$ & $\begin{array}{l}0.118^{* * *} \\
(0.039)\end{array}$ & $\begin{array}{l}0.120^{* * *} \\
(0.040)\end{array}$ & $\begin{array}{l}0.124^{* * *} \\
(0.040)\end{array}$ & $\begin{array}{l}0.119 * * * \\
(0.041)\end{array}$ \\
\hline
\end{tabular}

Each coefficient represents a separate regression. Coefficients are 2SLS estimates, with years on PL instrumented by the assignment to the reform. We use local linear regressions including triangular weights and separate

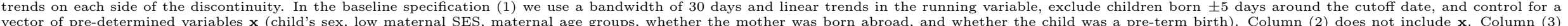
includes additional pre-determined controls for maternal daily real wage (mean over last 2 years before child birth), maternal occupation (white-collar/civil servant, blue-collar, self-employed/farmer), whether the mother was married, maternal education (6 indicators), maternal religious denomination (5 indicators), province ( 8 indicators), and whether the child had low birth weight. Column (4) includes the following community-level covariates: population size, population density, share of catholics, share of votes for conservative parties, share of married, share of pop. betw. 0 and 5 years, share of pop. betw. 0 and 15 years, female employment rate, the 
Table 8: Differences between communities with and w/o nursery by maternal work propensity

\begin{tabular}{|c|c|c|c|c|c|c|c|c|}
\hline & \multicolumn{4}{|c|}{ Low work propensity ${ }^{a}$} & \multicolumn{4}{|c|}{ High work propensity ${ }^{a}$} \\
\hline & $\begin{array}{l}\text { Communities } \\
\text { with nursery }\end{array}$ & $\begin{array}{l}\text { Communities } \\
\text { w/o nursery }\end{array}$ & Diff. & P-value & $\begin{array}{l}\text { Communities } \\
\text { with nursery }\end{array}$ & $\begin{array}{l}\text { Communities } \\
\text { w/o nursery }\end{array}$ & Diff. & P-value \\
\hline Predicted work propensity & 0.41 & 0.42 & $-0.01^{* *}$ & 0.01 & 0.64 & 0.61 & $0.03^{* *}$ & 0.00 \\
\hline Work in second year & 0.32 & 0.33 & -0.01 & 0.55 & 0.51 & 0.52 & -0.01 & 0.44 \\
\hline \multicolumn{9}{|l|}{ Baseline covariates: } \\
\hline Mother's age at birth & 24.42 & 23.37 & $1.05^{* *}$ & 0.00 & 25.76 & 24.61 & $1.15^{* *}$ & 0.00 \\
\hline Mother's socioeconomic status is high & 0.31 & 0.28 & $0.03^{*}$ & 0.05 & 0.68 & 0.62 & $0.06^{* *}$ & 0.00 \\
\hline Mother has foreign background & 0.02 & 0.01 & $0.01^{*}$ & 0.02 & 0.18 & 0.06 & $0.12^{* *}$ & 0.00 \\
\hline Child is female & 0.49 & 0.49 & 0.00 & 0.86 & 0.49 & 0.48 & 0.01 & 0.55 \\
\hline Preterm birth & 0.05 & 0.05 & 0.00 & 0.54 & 0.03 & 0.03 & -0.00 & 0.98 \\
\hline \multicolumn{9}{|l|}{ Other pre-determined variables: } \\
\hline \multicolumn{9}{|l|}{ Proxies for health at birth: } \\
\hline Gestation length (weeks) & 39.76 & 39.77 & -0.01 & 0.86 & 39.82 & 39.80 & 0.02 & 0.69 \\
\hline Birth weight (dekagram) & 321.56 & 321.90 & -0.34 & 0.85 & 325.72 & 325.25 & 0.47 & 0.75 \\
\hline Low birth weight $(<2500 \mathrm{~g})$ & 0.07 & 0.07 & 0.01 & 0.55 & 0.04 & 0.04 & -0.00 & 0.59 \\
\hline APGAR score after 5 min & 9.73 & 9.54 & $0.18^{* *}$ & 0.00 & 9.72 & 9.58 & $0.14^{* *}$ & 0.00 \\
\hline Maternity leave after birth (days) & 62.90 & 62.91 & -0.01 & 0.98 & 62.52 & 62.62 & -0.10 & 0.75 \\
\hline Mother was married at birth & 0.38 & 0.33 & $0.06^{* *}$ & 0.00 & 0.89 & 0.90 & -0.01 & 0.32 \\
\hline \multicolumn{9}{|l|}{ Mother's highest degree: } \\
\hline Compulsory education & 0.27 & 0.32 & $-0.05^{* *}$ & 0.00 & 0.13 & 0.10 & $0.03^{* *}$ & 0.01 \\
\hline Apprenticeship/intermediate & 0.64 & 0.66 & -0.01 & 0.42 & 0.52 & 0.68 & $-0.16^{* *}$ & 0.00 \\
\hline High school/college/university & 0.08 & 0.02 & $0.06^{* *}$ & 0.00 & 0.34 & 0.21 & $0.13^{* *}$ & 0.00 \\
\hline Mean pre-birth daily real wage & 37.26 & 38.70 & $-1.43^{*}$ & 0.05 & 57.00 & 53.47 & $3.53^{* *}$ & 0.00 \\
\hline \multicolumn{9}{|l|}{ Mother's occupation before birth: } \\
\hline Self-employed/farmer & 0.00 & 0.00 & 0.00 & 0.69 & 0.01 & 0.02 & -0.01 & 0.16 \\
\hline White-collar/civil servant & 0.51 & 0.40 & $0.11^{* *}$ & 0.00 & 0.84 & 0.82 & 0.02 & 0.20 \\
\hline Blue-collar & 0.35 & 0.53 & $-0.17^{* *}$ & 0.00 & 0.13 & 0.16 & $-0.02^{*}$ & 0.03 \\
\hline Missing & 0.13 & 0.07 & $0.06^{* *}$ & 0.00 & 0.02 & 0.00 & $0.01^{* *}$ & 0.00 \\
\hline Number of observations & 1,174 & 3,308 & & & 1,481 & 3,002 & & \\
\hline
\end{tabular}

Notes: This table summarizes sample means of the samples of mothers who gave birth in communities with a nursery and mothers who gave birth in communities without a nursery, the difference in the two sample means, and the p-value resulting from a $t$ test on the equality of means separately for mothers with a low/high predicted propensity to work in the second year after childbirth (for our estimation sample). * and ${ }^{* *}$ indicate statistical significance at the 5-percent and 1-percent level. ${ }^{a}$ Maternal characteristics indicate a low/high propensity of being employed in the second year after childbirth, low/high according to median prediction in the sample (0.52). 
Table 9: Child outcomes by availability of nursery \& maternal work propensity

\begin{tabular}{|c|c|c|c|c|c|c|}
\hline & \multicolumn{3}{|c|}{ Low work propensity ${ }^{a}$} & \multicolumn{3}{|c|}{ High work propensity ${ }^{a}$} \\
\hline & $\begin{array}{l}\text { Communities } \\
\text { with nursery }\end{array}$ & $\begin{array}{l}\text { Communities } \\
\text { w/o nursery }\end{array}$ & $\begin{array}{c}\mathrm{P} \text {-value } \\
\Delta^{b}\end{array}$ & $\begin{array}{l}\text { Communities } \\
\text { with nursery }\end{array}$ & $\begin{array}{l}\text { Communities } \\
\text { w/o nursery }\end{array}$ & $\begin{array}{c}\mathrm{P} \text {-value } \\
\Delta^{b}\end{array}$ \\
\hline$\%$ in Sample & 13.1 & 36.9 & & 16.5 & 33.5 & \\
\hline Active (age 17) & $\begin{array}{c}0.026 \\
(0.028)\end{array}$ & $\begin{array}{c}0.006 \\
(0.011)\end{array}$ & 0.519 & $\begin{array}{c}0.009 \\
(0.036)\end{array}$ & $\begin{array}{l}0.027^{* *} \\
(0.013)\end{array}$ & 0.633 \\
\hline Active (age 23) & $\begin{array}{c}0.004 \\
(0.055)\end{array}$ & $\begin{array}{c}-0.008 \\
(0.029)\end{array}$ & 0.840 & $\begin{array}{c}-0.056 \\
(0.056)\end{array}$ & $\begin{array}{l}0.077^{* *} \\
(0.030)\end{array}$ & 0.035 \\
\hline Active (age 17-23) & $\begin{array}{c}0.002 \\
(0.033)\end{array}$ & $\begin{array}{l}0.016 \\
(0.017)\end{array}$ & 0.703 & $\begin{array}{c}0.028 \\
(0.047)\end{array}$ & $\begin{array}{l}0.049^{* * *} \\
(0.019)\end{array}$ & 0.674 \\
\hline Non-disabled & $\begin{array}{c}0.015 \\
(0.049)\end{array}$ & $\begin{array}{c}0.027 \\
(0.020)\end{array}$ & 0.820 & $\begin{array}{c}-0.021 \\
(0.030)\end{array}$ & $\begin{array}{l}0.051^{* *} \\
(0.026)\end{array}$ & 0.072 \\
\hline Fit for military (boys) & $\begin{array}{c}0.114 \\
(0.109)\end{array}$ & $\begin{array}{c}0.075 \\
(0.053)\end{array}$ & 0.746 & $\begin{array}{c}-0.047 \\
(0.081)\end{array}$ & $\begin{array}{l}0.185^{* * *} \\
(0.060)\end{array}$ & 0.022 \\
\hline
\end{tabular}

Notes: Estimation results are based on fully interacted models, estimated separately for mothers with low and high work propensity. Coefficients are based on 2SLS estimations, with years on parental leave instrumented by the assignment to the reform (both interacted with indicators for communities with and without nursery). We use local linear regressions including triangular weights and separate linear trends on each side of the discontinuity. We use a bandwidth of 30 days, exclude children born \pm 5 days around the cutoff date, and control for the child's sex, low maternal SES, maternal age groups, whether the mother was born abroad, and whether the child was a pre-term birth. Standard errors (shown in parentheses) are clustered at the community level. * ** and *** indicate statistical significance at the 10-percent, 5-percent and 1-percent level, ${ }^{a}$ Maternal characteristics indicate a low/high propensity of being employed $>0$ days in the second year after childbirth, low/high according to median prediction $(0.51)$

${ }^{b}$ Prob $>\mathrm{F}$ (chi2) of difference in coefficients between mothers living in communities with and without nursery. 
Table 10: Sensitivity: Child outcomes by availability of nursery \& maternal work propensity - community characteristics

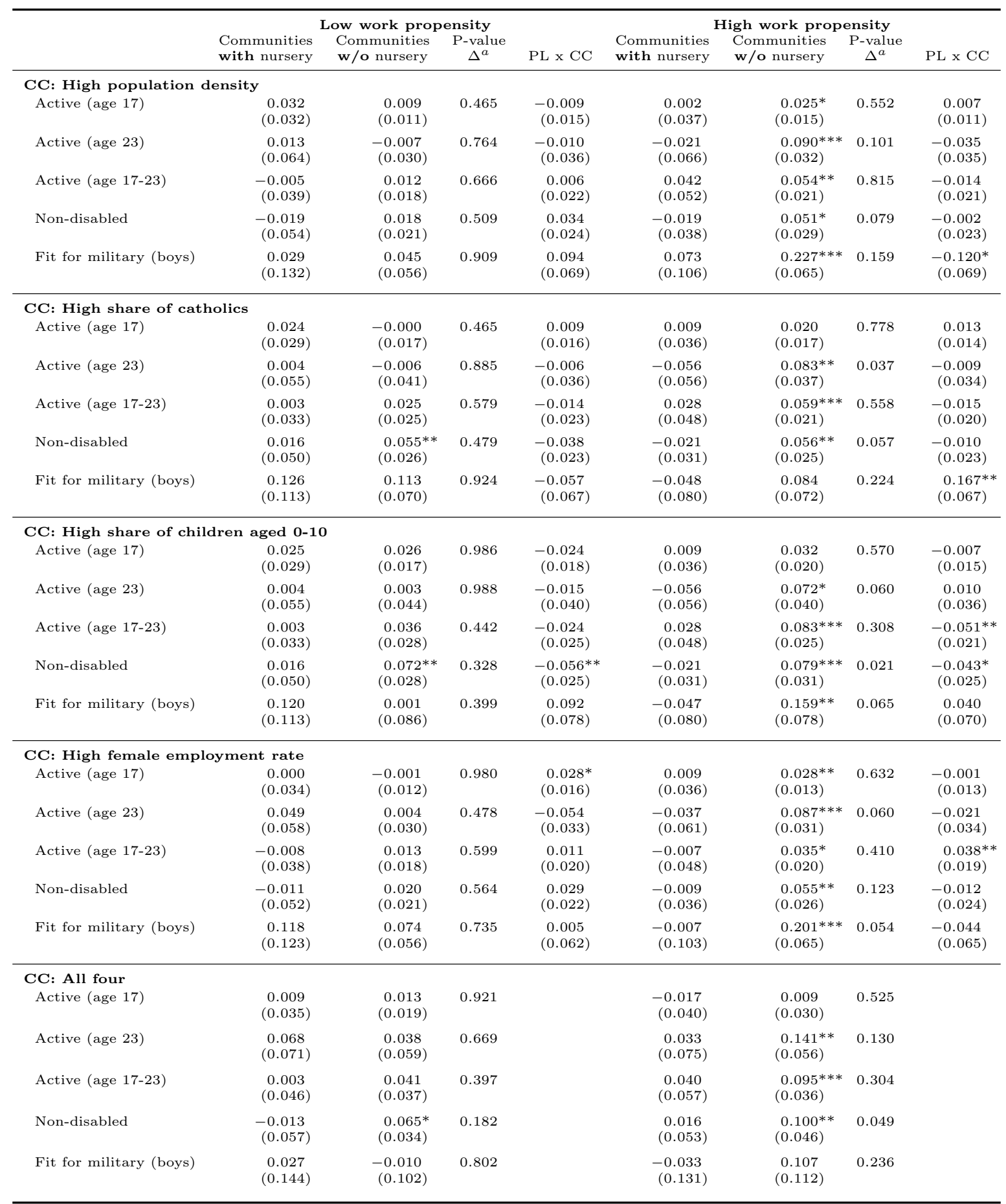

Notes: Estimation results are based on fully interacted models, estimated separately for mothers with low and high work propensity. with incients are based on 2SLS estimations, with years on parental leave instrumented by the assignment to the reform (both interacted indicator for for communities with and without nursery). We further interact years on parental leave and assignent with an characteristic (CC). We use local linear regressions including triangular weights and separate linear trends on each side of the discontinuity. We use a bandwidth of 30 days, exclude children born \pm 5 days around the cutoff date, and control for the child' dis, sex, low methe the community had a nursery, and whether the mother lived in a community with a high value of CC. Standard errors (shown in
parentheses) are clustered at the community level. *,** and *** indicate statistical significance at the 10-percent, 5-percent and 1-percent level. 
Table 11: Sensitivity: Child outcomes - cond. on family size and maternal (fulltime) employment

\begin{tabular}{|c|c|c|c|c|}
\hline & $\begin{array}{c}\text { All } \\
\text { communities }\end{array}$ & $\begin{array}{l}\text { Communities } \\
\text { with nursery }\end{array}$ & $\begin{array}{l}\text { Communities } \\
\text { w/o nursery }\end{array}$ & $\begin{array}{r}\mathrm{P} \text {-value } \\
\Delta^{a}\end{array}$ \\
\hline \multicolumn{5}{|c|}{ Number of children \& maternal emp. ${ }^{b}$} \\
\hline Active (age 17) & $\begin{array}{c}0.015 \\
(0.009)\end{array}$ & $\begin{array}{c}0.016 \\
(0.023)\end{array}$ & $\begin{array}{c}0.016^{*} \\
(0.008)\end{array}$ & 0.973 \\
\hline Active (age 23) & $\begin{array}{c}0.012 \\
(0.018)\end{array}$ & $\begin{array}{c}-0.021 \\
(0.038)\end{array}$ & $\begin{array}{c}0.026 \\
(0.020)\end{array}$ & 0.272 \\
\hline Active (age $17-23$ ) & $\begin{array}{c}0.024^{*} \\
(0.013)\end{array}$ & $\begin{array}{c}0.016 \\
(0.033)\end{array}$ & $\begin{array}{l}0.029^{* *} \\
(0.013)\end{array}$ & 0.708 \\
\hline Non-disabled & $\begin{array}{c}0.025^{*} \\
(0.014)\end{array}$ & $\begin{array}{c}-0.001 \\
(0.026)\end{array}$ & $\begin{array}{l}0.041^{* *} \\
(0.016)\end{array}$ & 0.167 \\
\hline Fit for military (boys) & $\begin{array}{l}0.097^{* * *} \\
(0.034)\end{array}$ & $\begin{array}{c}0.037 \\
(0.071)\end{array}$ & $\begin{array}{l}0.124^{* * *} \\
(0.040)\end{array}$ & 0.282 \\
\hline \multicolumn{5}{|c|}{ Number of children \& maternal full-time emp. ${ }^{c}$} \\
\hline Active (age 17 ) & $\begin{array}{c}0.014 \\
(0.009)\end{array}$ & $\begin{array}{c}0.007 \\
(0.023)\end{array}$ & $\begin{array}{l}0.019^{* *} \\
(0.009)\end{array}$ & 0.601 \\
\hline Active (age 23) & $\begin{array}{c}0.022 \\
(0.018)\end{array}$ & $\begin{array}{c}-0.006 \\
(0.034)\end{array}$ & $\begin{array}{c}0.032 \\
(0.022)\end{array}$ & 0.344 \\
\hline Active (age $17-23$ ) & $\begin{array}{l}0.027^{* *} \\
(0.013)\end{array}$ & $\begin{array}{c}0.018 \\
(0.032)\end{array}$ & $\begin{array}{l}0.032^{* *} \\
(0.014)\end{array}$ & 0.702 \\
\hline Non-disabled & $\begin{array}{c}0.023 \\
(0.015)\end{array}$ & $\begin{array}{c}-0.014 \\
(0.030)\end{array}$ & $\begin{array}{l}0.044^{* * *} \\
(0.017)\end{array}$ & 0.097 \\
\hline Fit for military (boys) & $\begin{array}{l}0.107^{* * *} \\
(0.035)\end{array}$ & $\begin{array}{c}0.019 \\
(0.064)\end{array}$ & $\begin{array}{l}0.146^{* * *} \\
(0.041)\end{array}$ & 0.093 \\
\hline
\end{tabular}

Notes: Each row represents two separate regressions. Estimation results by availability of nursery are based on fully interacted models. Coefficients based on 2SLS estimations, with years on parental leave instrumented by the assignment to the reform. We use local linear regressions including triangular weights and separate trends before and after the cutoff. We use a bandwidth of 30 days, exclude children born \pm 5 days around the cutoff date, and control for the child's sex, low maternal SES, maternal age groups, whether the mother was born abroad, and whether the child was a pre-term birth. Standard errors (shown in parentheses) are clustered at the community level. *,** and $* * *$ indicate statistical significance at the 10-percent, 5-percent and 1-percent level. ${ }^{a}$ Prob $>\mathrm{F}$ (chi2) of difference in coefficients between communities with and w/o nursery. ${ }^{b}$ Additional control variables: number of children and binary indicators for maternal employment 3,5 , and 10 years after birth. ${ }^{c}$ Additional control variables: number of children and binary indicators for maternal full-time employment 3,5 , and 10 years after birth. 


\section{Web appendix}

This Web appendix (not for publication) provides additional material discussed in the manuscript 'Parental Leave, (In)formal Childcare and Long-term Child Outcomes' by Natalia Danzer, Martin Halla, Nicole Schneeweis, and Martina Zweimüller. It comprises two section. The first section (A.1) discusses the effects of the PL reform on educational performance. The second section (A.2) contains additional estimation results.

\section{A.1 Effects of the PL reform on educational performance}

\section{A.1.1 Data}

To assess the effect of the Austrian PL reform from 1990 on educational outcomes, we use PISA data from 2003 and 2006 and data from the Educational Register of the city of Linz (EducReg). ${ }^{1}$ These data sets have several drawbacks compared with the register data that we use in our main analysis. First, these data do not cover the universe of births. PISA includes a representative sample of about 5,000 children aged 15/16 years at the time of testing. Thus, in PISA 2006 the 1990 birth cohort was sampled and in PISA 2003 we observe the 1987 birth cohort. The EducReg includes all children residing in Linz. Second, since these data do not include information on the mother's eligibility or actual PL takeup, we can only estimate ITTs. Third, we cannot impose the same sample restrictions, because these data sets lack information on birth order, multiple births, and the exact birth date (only the month of birth is available). Since the EducReg provides no information on the child's country of birth, we exclude all students with foreign language or citizenship. ${ }^{2}$ Fourth, we adapt our econometric model, since we can not include trends in the running variable (birthdate). Fifth, the set of covariates is smaller. Sixth, the PISA and EducReg lack information on community of birth. Instead, our analysis of the EducReg is based on all children residing in Linz (at the time when we measure educational outcomes). While we know that nurseries were available in Linz in 1990, we do not know whether each of these children was actually born in a community with a nursery. In our analysis of the PISA data we observe the size of the community (in bands) in which the school is located and use a cutoff of 100,000 inhabitants to stratify the sample (since neither the community of birth nor the community of residence is observed). We know that communities with more than 100,000 inhabitants had a nursery in 1990, whereas almost all communities with fewer than 100,000 did not. Given these data restrictions, the results with respect to treatment effect heterogeneity have to be interpreted with caution.

\footnotetext{
${ }^{1}$ Linz is the third-largest city of Austria and the capital of the state of Upper Austria. Upper Austria is one of nine federal states in Austria. It comprises about one sixth of the Austrian population and workforce.

${ }^{2}$ This sample restrictions aims to exclude children, who were potentially not exposed to the Austrian PL system. Austria witnessed a large influx of migrants post 1993.
} 


\section{A.1.2 Children's educational outcomes}

We analyze PISA test scores in the fields of mathematics, science, and reading achieved at age 15/16. Further, we check which school track the child attended in grades 8 and 9 . This information is contained in the EducReg sample (Linz) (grade 8) and the PISA data (grade 9), respectively. Table A.1 provides a description of the outcome variables.

Note that Austria has a system of early tracking. After primary school, students are allocated to two educational tracks. Higher secondary schools (the high track) comprise grades 5 to $12 / 13$, provide advanced education, and conclude with a university entrance exam. Lower secondary schools (the low track) comprise grades 5 to 8, provide basic general education, and prepare students for vocational education either within an intermediate vocational school or within the dual education system. The dual education system combines an apprenticeship in a firm and (vocational) education at a vocational school. In the EducReg sample (Linz), we observe school tracks in grade 8. About 39 percent are in the high track, respectively. This share is above the national average (30 percent). ${ }^{3}$ In the PISA sample, which covers students in grade 9 and is representative of Austria, about 63 percent of students are in the high track. ${ }^{4}$

Table A.1: Description of children's educational outcomes variables

\begin{tabular}{|c|c|c|c|c|c|c|}
\hline Outcome & Variable description & Data source $^{a}$ & $N$ & $\begin{array}{c}\text { All } \\
\text { Mean }\end{array}$ & $\begin{array}{l}\text { Communit } \\
\text { with } \\
\text { nurseries } \\
\text { Mean }\end{array}$ & $\begin{array}{l}\text { w/o } \\
\text { nurseries } \\
\text { Mean }\end{array}$ \\
\hline Test score math & $\begin{array}{l}\text { This variable captures the tests core in } \\
\text { mathematics (age 15/16). }\end{array}$ & PISA & 1,405 & 522 & 526 & 520 \\
\hline Test score science & $\begin{array}{l}\text { This variable captures the tests core in sci- } \\
\text { ence (age } 15 / 16) \text {. }\end{array}$ & PISA & 1,405 & 506 & 510 & 503 \\
\hline Test score reading & $\begin{array}{l}\text { This variable captures the tests core in } \\
\text { reading (age } 15 / 16 \text { ). }\end{array}$ & PISA & 1,405 & 519 & 520 & 517 \\
\hline High track grade 8 & $\begin{array}{l}\text { Binary indicator equal to one if child is in } \\
\text { the high track in grade } 8 \text { (age } 13 / 14 \text { ). }\end{array}$ & EducReg & 456 & - & 0.386 & - \\
\hline High track grade 9 & $\begin{array}{l}\text { Binary indicator equal to one if child is in } \\
\text { the high track in grade } 9 \text { (age } 14 / 15 \text { ). }\end{array}$ & PISA & 1,386 & 0.560 & 0.630 & 0.526 \\
\hline
\end{tabular}

Notes: ${ }^{a}$ PISA $=$ Programme for International Student Assessment, EducReg = Educational Register of the city of Linz

\section{A.1.3 Empirical strategy}

Since the data do not contain information on actual maternal PL duration, we estimate the following intention-to-treat effects:

$$
O_{i}=\gamma_{0}+\gamma_{1} T_{i}+\gamma_{2} A_{i}+\mathbf{x}_{\mathbf{i}} \phi^{\prime}+\tau_{c}+\omega_{i}
$$

\footnotetext{
${ }^{3}$ Data for the school year 2005/06 show that around 30 percent of all Austrian children attended the high track in grade 8. This share was higher in urban areas, 37 percent in Linz and 46 percent in Vienna (Schneeweis and Zweimüller, 2012).

${ }^{4}$ Data for the school year 2006/07 show that after grade 8 about a third of graduates from the low track transfer to the high track (Schneeweis and Zweimüller, 2012).
} 


\section{A.1.4 Educational outcomes: Average effects}

Our complementary analysis on educational outcomes does not reveal any significant effects of the PL in the full sample (see Table A.2). The ITT estimates suggest that, on average, the PL extension did neither significantly affect PISA test scores nor the likelihood of high track attendance in secondary school. These results are robust to the exclusion (column 2) or addition of a rich set of covariates (column 3) and to the exclusion of children with foreign-born mothers from the sample (column 4). However, it is important to keep in mind that these estimations are based on much smaller samples and include children whose mothers were not eligible to PL. All coefficients on the PISA test scores have a positive sign and correspond in size to about 8 to 10 percent of a standard deviation, but are too imprecisely estimated to be statistically significantly different from zero.

Table A.2: Average child educational outcomes

\begin{tabular}{|c|c|c|c|c|}
\hline & $\begin{array}{c}\text { (1) } \\
\text { Baseline }\end{array}$ & $\begin{array}{c}(2) \\
\text { No } \\
\text { covariates }\end{array}$ & $\begin{array}{c}(3) \\
\text { More } \\
\text { covariates }\end{array}$ & $\begin{array}{c}(4) \\
\text { Exclude } \\
\text { migrants }\end{array}$ \\
\hline Test score math (age 15/16) & $\begin{array}{c}13.168 \\
(10.880)\end{array}$ & $\begin{array}{c}8.646 \\
(11.438)\end{array}$ & $\begin{array}{c}10.398 \\
(12.206)\end{array}$ & $\begin{array}{c}8.422 \\
(11.546)\end{array}$ \\
\hline Test score science (age 15/16) & $\begin{array}{c}11.487 \\
(11.274)\end{array}$ & $\begin{array}{c}8.540 \\
(11.865)\end{array}$ & $\begin{array}{c}7.361 \\
(12.829)\end{array}$ & $\begin{array}{c}7.221 \\
(11.767)\end{array}$ \\
\hline Test score reading (age 15/16) & $\begin{array}{c}9.806 \\
(11.159)\end{array}$ & $\begin{array}{c}8.180 \\
(12.012)\end{array}$ & $\begin{array}{c}8.036 \\
(12.587)\end{array}$ & $\begin{array}{c}6.298 \\
(11.796)\end{array}$ \\
\hline High track grade 9 (age 14/15) & $\begin{array}{c}0.022 \\
(0.048)\end{array}$ & $\begin{array}{c}0.019 \\
(0.051)\end{array}$ & $\begin{array}{r}-0.019 \\
(0.054)\end{array}$ & $\begin{array}{c}0.006 \\
(0.050)\end{array}$ \\
\hline \multicolumn{5}{|c|}{$\begin{array}{l}\text { Each coefficient represents a separate regression based on survey data from PISA. Coefficients } \\
\text { represent reduced form estimates. We use a sample of children born in Austria in June/July } \\
1987 / 1990 \text {. In the baseline specification, presented in column (1), we control for the child's } \\
\text { sex, low maternal SES (based on education), whether the mother was born abroad and birth- } \\
\text { year and birth-month fixed-effects. Column (2) includes only controls for birth-year and } \\
\text { birth-month. Column (3) includes additional indicators for maternal occupation and skills } \\
\text { (4 groups) and the maternal socioeconomic index of occupational status (ISEI). Column } \\
\text { (4) drops all foreign-born mothers from the sample. Robust standard errors are shown in } \\
\text { parentheses. Estimations control for the survey design (school clusters, student weights). *, } \\
* * \text { and } \text { t }^{* *} \text { indicate statistical significance at the 10-percent, } 5 \text {-percent and 1-percent level. }\end{array}$} \\
\hline
\end{tabular}

\section{A.1.5 Educational outcomes: Heterogeneity analysis}

The heterogeneity analysis by availability of nursery at the time of birth yields similarly striking differences (despite the inferior data quality). As the results in Table A.3 suggest, the PL reform significantly improved the educational outcomes in communities without nurseries, but had zero to negative effects on educational performance in communities with nurseries.

As regards the PISA test scores, the estimated effects on the test scores in science and reading differ significantly between communities. In communities with childcare facilities, the 
coefficients are negative for all three subjects, although statistically significant only in reading. By contrast, we obtain positive and statistically significant effects in communities where childcare is unavailable. The positive coefficients on the test scores amount to about one quarter of the standard deviations in these variables. In addition to the test scores, we investigate high track attendance in different grades; however, we do not find any significant effects in grade 9. By contrast, significant negative effects are obtained for high track attendance in grade 8 in Linz (a community with a nursery). These results are robust to adjustments in the set of covariates and in the sample specification (see Table A.4).

Table A.3: Children's educational outcomes by availability of nursery (proxy)

\begin{tabular}{lccr}
\hline & $\begin{array}{c}\text { Communities } \\
\text { with nursery }^{a}\end{array}$ & $\begin{array}{c}\text { Communities } \\
\text { w/o nursery }\end{array}$ & $\begin{array}{r}\text { P-value } \\
\Delta^{c}\end{array}$ \\
\hline Test score math (age 15/16) & -11.833 & $21.712^{*}$ & 0.179 \\
& $(21.431)$ & $(12.527)$ & \\
Test score science (age 15/16) & -27.516 & $23.435^{*}$ & 0.032 \\
& $(20.216)$ & $(12.811)$ & \\
Test score reading (age 15/16) & $-39.839^{* *}$ & $27.161^{* *}$ & 0.005 \\
& $(20.274)$ & $(12.627)$ & \\
High track grade 9 (age 14/15) & 0.027 & 0.012 & 0.891 \\
& $(0.094)$ & $(0.056)$ & \\
High track grade 8 (age 13/14) & $-0.213^{* *}$ & & \\
& $(0.091)$ & &
\end{tabular}

Notes: Each row represents a separate regression based on survey data from PISA and register data from EducReg Linz. Estimation results are based on fully interacted models. Coefficients represent reduced form estimates. We use a sample of children born in Austria in June/July 1987/1990 in PISA (1989/1990 in EducReg). Each specification controls for the child's sex, low maternal SES, whether the mother was born abroad (only PISA sample) and birth-year and birth-month fixed-effects. Robust standard errors are shown in parentheses. Estimations for PISA education outcomes control for the survey design (school clusters, student weights). * ${ }^{* *}$ and $* * *$ indicate statistical significance at the 10-percent, 5-percent and 1-percent level. ${ }^{a}$ The child attends a school in a community with $\geq 100,000$ inhabitants. ${ }^{b}$ The child attends a school in a community with $<100,000$ inhabitants. ${ }^{c}$ Prob $>F($ chi2) of diff. in coefficients between communities with and w/o nursery. 
Table A.4: Sensitivity: Children's educational outcomes by availability of nursery (proxy)

\begin{tabular}{|c|c|c|c|c|c|c|c|c|}
\hline & \multicolumn{4}{|c|}{ Communities with nursery ${ }^{a}$} & \multicolumn{4}{|c|}{ Communities w/o nursery ${ }^{b}$} \\
\hline & $\begin{array}{c}(1) \\
\text { Baseline }\end{array}$ & $\begin{array}{c}(2) \\
\text { No } \\
\text { covariates }\end{array}$ & $\begin{array}{c}(3) \\
\text { More } \\
\text { covariates }\end{array}$ & $\begin{array}{c}(4) \\
\text { Exclude } \\
\text { migrants }\end{array}$ & $\begin{array}{c}(1) \\
\text { Baseline }\end{array}$ & $\begin{array}{c}(2) \\
\text { No } \\
\text { covariates }\end{array}$ & $\begin{array}{c}(3) \\
\text { More } \\
\text { covariates }\end{array}$ & $\begin{array}{c}(4) \\
\text { Exclude } \\
\text { migrants }\end{array}$ \\
\hline Test score math (age 15/16) & $\begin{array}{c}-11.833 \\
(21.499)\end{array}$ & $\begin{array}{c}-25.090 \\
(23.219)\end{array}$ & $\begin{array}{c}-26.898 \\
(21.129)\end{array}$ & $\begin{array}{c}-27.656 \\
(24.018)\end{array}$ & $\begin{array}{c}21.712^{*} \\
(12.536)\end{array}$ & $\begin{array}{c}19.500 \\
(13.228)\end{array}$ & $\begin{array}{c}19.157 \\
(14.245)\end{array}$ & $\begin{array}{c}19.914 \\
(13.015)\end{array}$ \\
\hline Test score science (age 15/16) & $\begin{array}{c}-27.516 \\
(20.280)\end{array}$ & $\begin{array}{c}-39.560^{*} \\
(21.371)\end{array}$ & $\begin{array}{c}-46.506^{* *} \\
(20.782)\end{array}$ & $\begin{array}{c}-44.747^{* *} \\
(21.963)\end{array}$ & $\begin{array}{c}23.435^{*} \\
(12.821)\end{array}$ & $\begin{array}{c}22.720^{*} \\
(13.352)\end{array}$ & $\begin{array}{c}22.095 \\
(14.865)\end{array}$ & $\begin{array}{c}22.758^{*} \\
(13.283)\end{array}$ \\
\hline Test score reading (age 15/16) & $\begin{array}{c}-39.839^{*} \\
(20.338)\end{array}$ & $\begin{array}{c}-50.207^{* *} \\
(21.786)\end{array}$ & $\begin{array}{c}-55.875^{* * *} \\
(20.368)\end{array}$ & $\begin{array}{c}-55.177^{* *} \\
(22.834)\end{array}$ & $\begin{array}{l}27.161^{* *} \\
(12.636)\end{array}$ & $\begin{array}{c}27.403^{* *} \\
(13.447)\end{array}$ & $\begin{array}{c}28.031^{*} \\
(14.614)\end{array}$ & $\begin{array}{l}26.159^{* *} \\
(13.196)\end{array}$ \\
\hline High track grade 9 (age 14/15) & $\begin{array}{c}0.027 \\
(0.095)\end{array}$ & $\begin{array}{c}0.000 \\
(0.097)\end{array}$ & $\begin{array}{c}-0.064 \\
(0.099)\end{array}$ & $\begin{array}{c}-0.028 \\
(0.100)\end{array}$ & $\begin{array}{c}0.012 \\
(0.056)\end{array}$ & $\begin{array}{c}0.012 \\
(0.061)\end{array}$ & $\begin{array}{c}-0.009 \\
(0.065)\end{array}$ & $\begin{array}{c}0.013 \\
(0.057)\end{array}$ \\
\hline High track grade 8 (age $13 / 14$ ) & $\begin{array}{c}-0.213^{* *} \\
(0.091)\end{array}$ & $\begin{array}{c}-0.190^{* *} \\
(0.092)\end{array}$ & $\begin{array}{c}-0.154^{*} \\
(0.093)\end{array}$ & & & & & \\
\hline
\end{tabular}

Each coefficient represents a separate regression based on data from PISA and EducReg Linz. Coefficients are reduced form estimates. We use a sample of children born in Austria in June/July 1987/1990 in PISA (1989/1990 in EducReg). In the baseline specification, presented in column (1), we control for the child's sex, low maternal SES, whether the mother was born abroad (only PISA sample), and birth-year and birth-month fixed-effects. Column (2) includes only birth-year and birth-month fixed-effects. Column (3) includes additional indicators for maternal occupation and skills (4 groups) and the maternal socioeconomic index of occupational status (ISEI) in the PISA sample, and indicators for districts in the EducReg Linz sample. Column (4) drops all foreign-born mothers from the sample. Robust standard errors are shown in parentheses. Estimations for PISA education outcomes control for the survey design (school clusters, student weights). $*, * *$ and Robust standard errors are shown in parentheses. Estimations for PISA education outcomes control for the survey design (school clusters, student weights). ${ }_{* * *}^{*}$ indicate statistical significance at the 10 -percent, 5 -percent and 1 -percent level. ${ }^{a}$ The child attends a school in a community with $\geq 100,000$ inhabitants. ${ }^{b}$ The
The $* * *$ indicate statistical significance at the 10 -percent, 5 -percent and
child attends a school in a community with $<100,000$ inhabitants. 
A.2 Additional tables and figures 


\section{Figure A.1: All communities}

(a) Active (age 17)
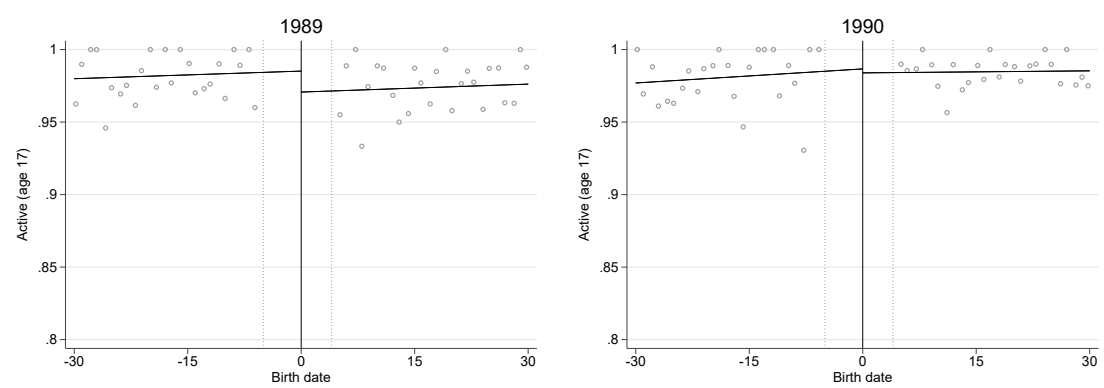

(b) Active (age 23)
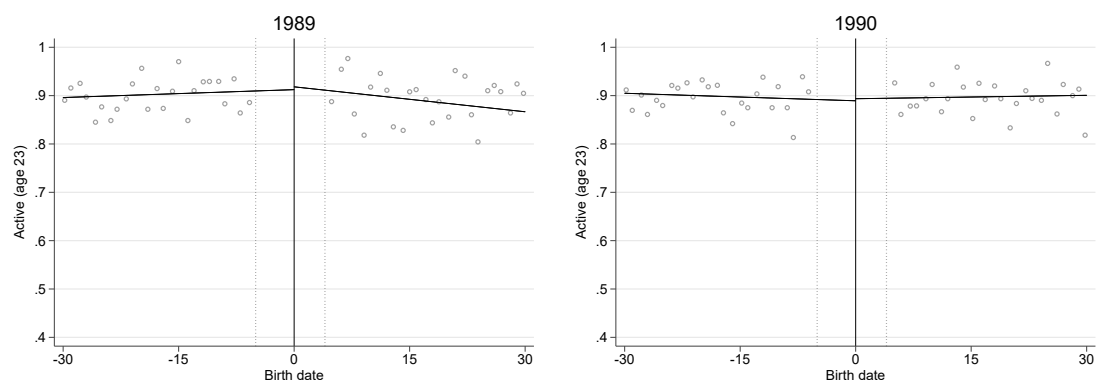

(c) Active (age 17-23)
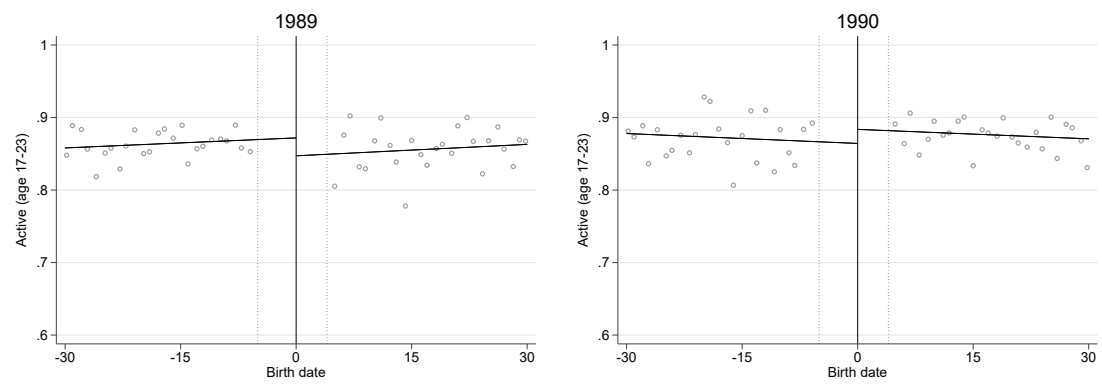

(d) Non-disabled
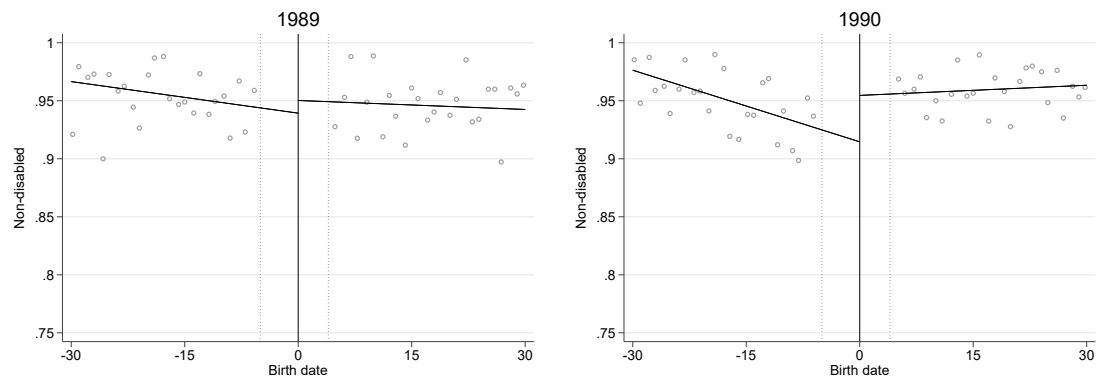

(e) Fit for military (boys)
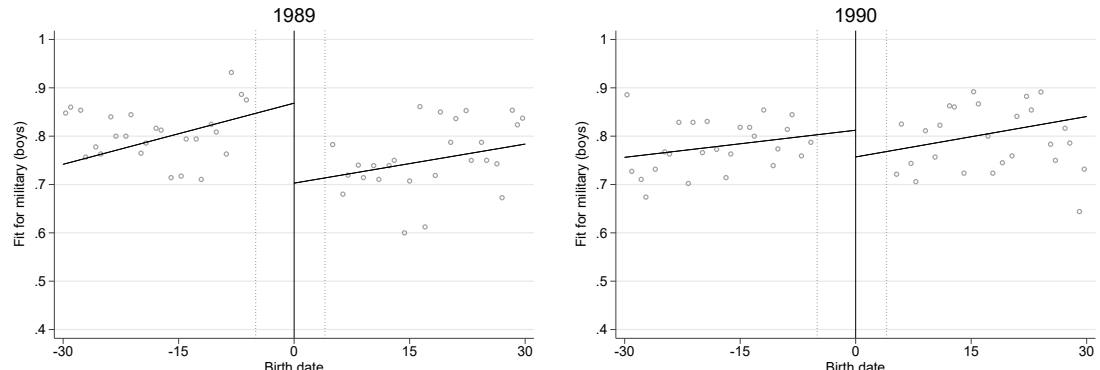

Notes: Variance RD plots with evenly-spaced bins. Circles are local sample means within bins. The solid line is a fitted triangular local linear regression with a bandwidth of 30 days (exluding observations \pm 5 days around the cutoff). 


\section{Figure A.2: Communities with nurseries}

(a) Active (age 17)
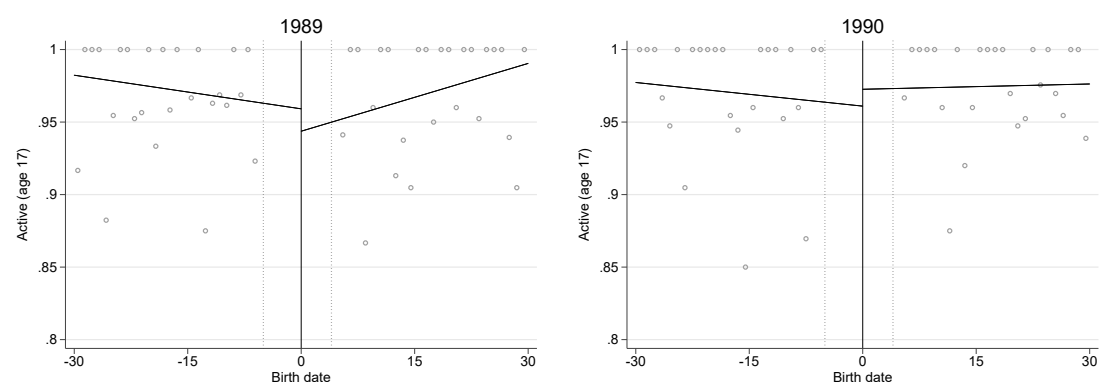

(b) Active (age 23)
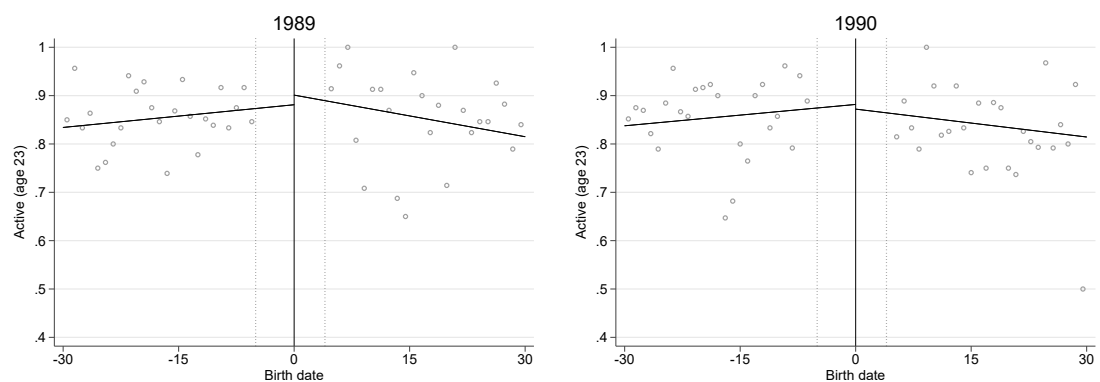

(c) Active (age 17-23)
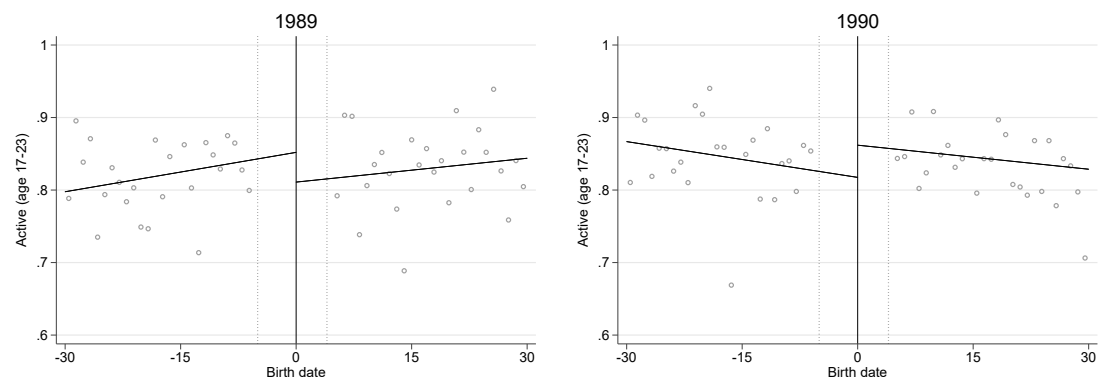

(d) Non-disabled
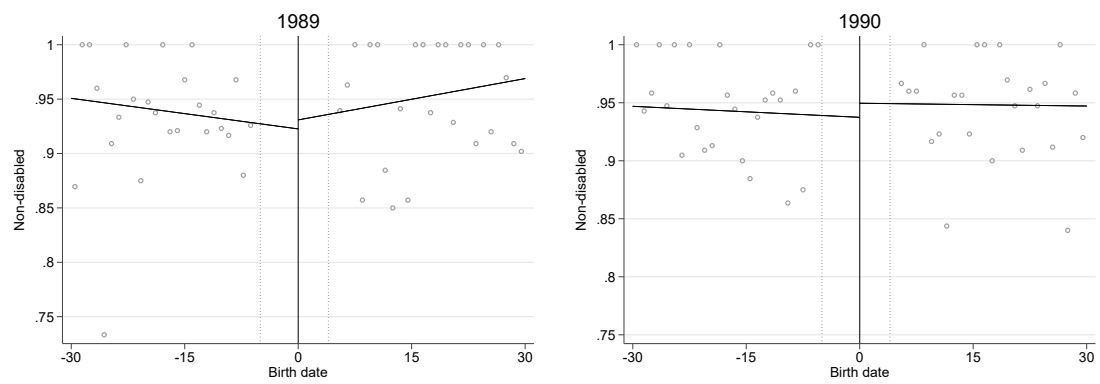

(e) Fit for military (boys)
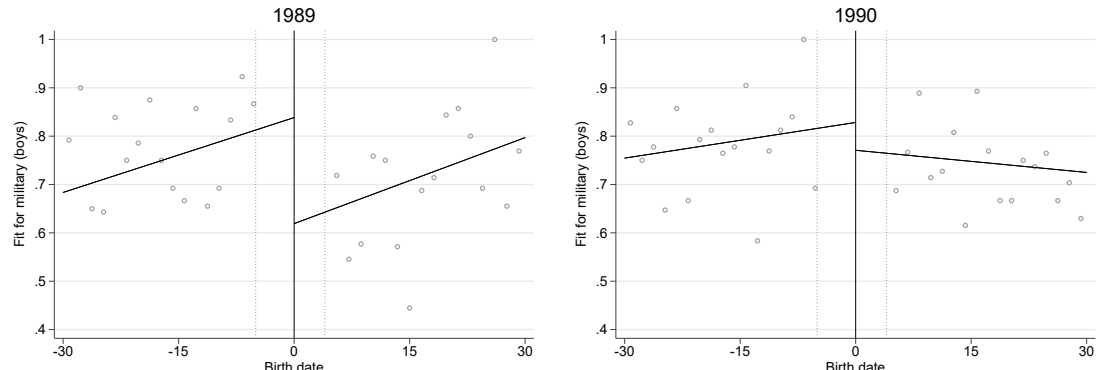

Notes: Variance RD plots with evenly-spaced bins. Circles are local sample means within bins. The solid line is a fitted triangular local linear regression with a bandwidth of 30 days (exluding observations \pm 5 days around the cutoff). 


\section{Figure A.3: Communities w/o nurseries}

(a) Active (age 17)
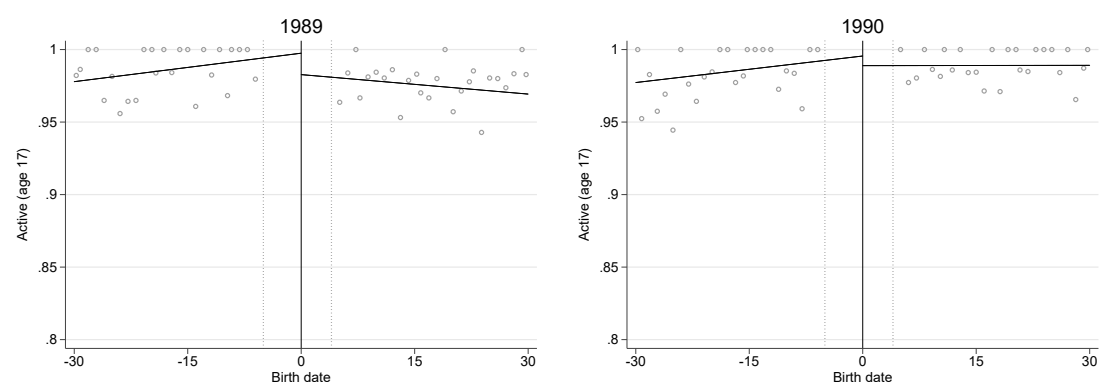

(b) Active (age 23)
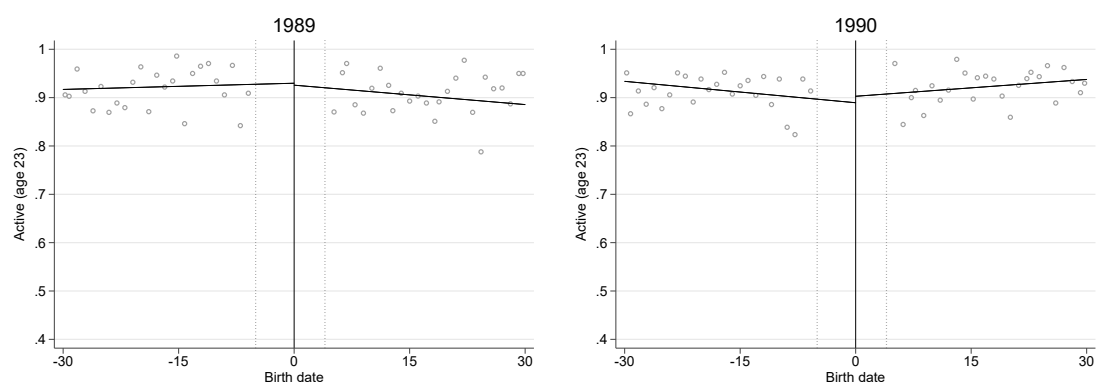

(c) Active (age 17-23)
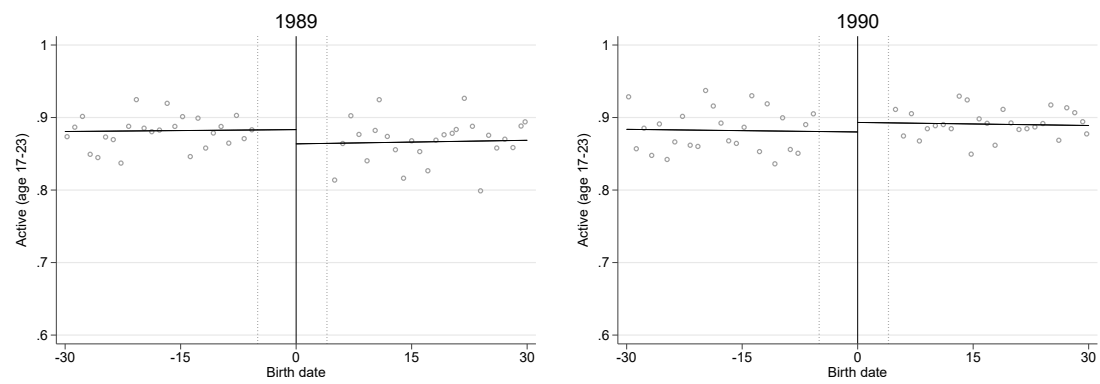

(d) Non-disabled
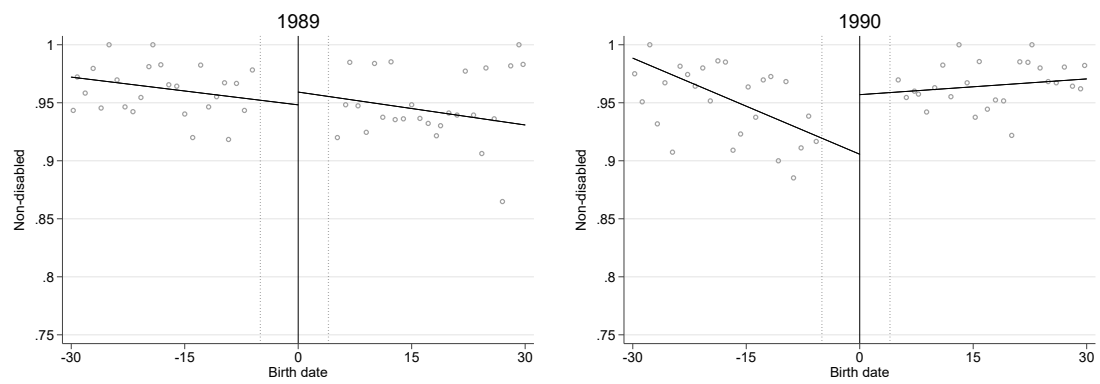

(e) Fit for military (boys)
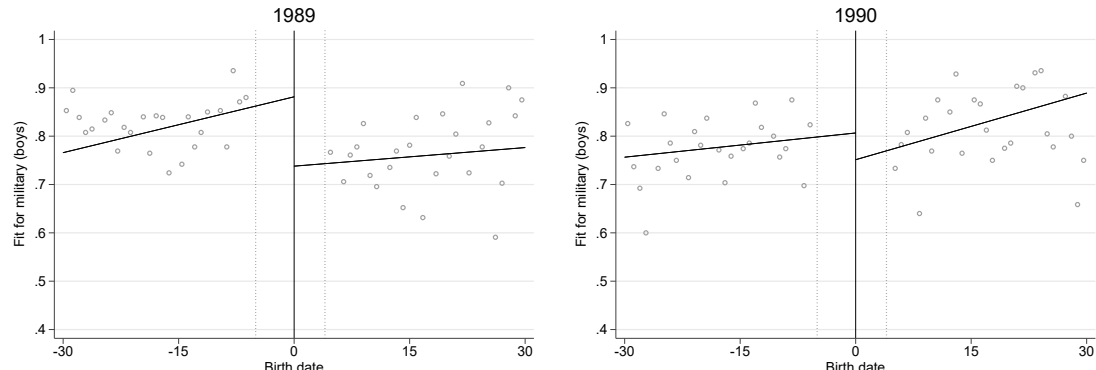

Notes: Variance RD plots with evenly-spaced bins. Circles are local sample means within bins. The solid line is a fitted triangular local linear regression with a bandwidth of 30 days (exluding observations \pm 5 days around the cutoff). 


\section{Figure A.4: Sensitivity with respect to donut choice}

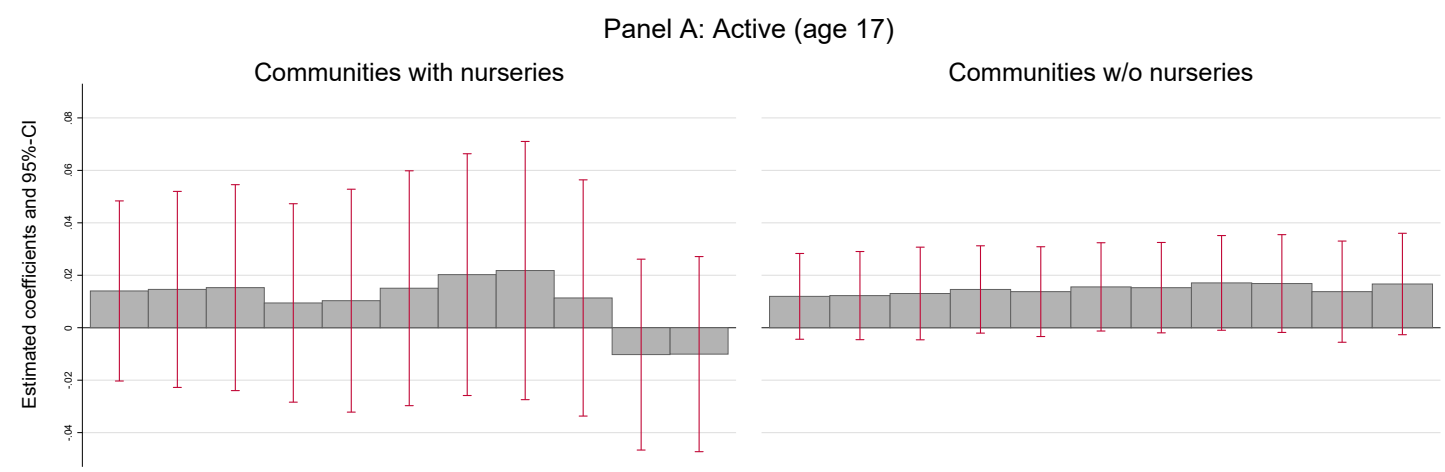

Panel B: Active (age 23)

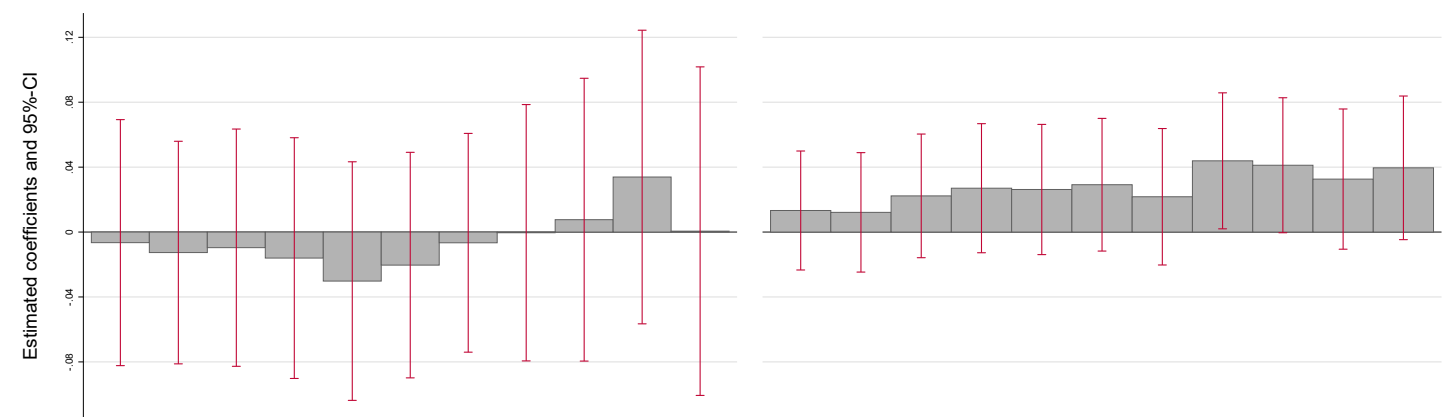

Panel C: Active (age 17-23)
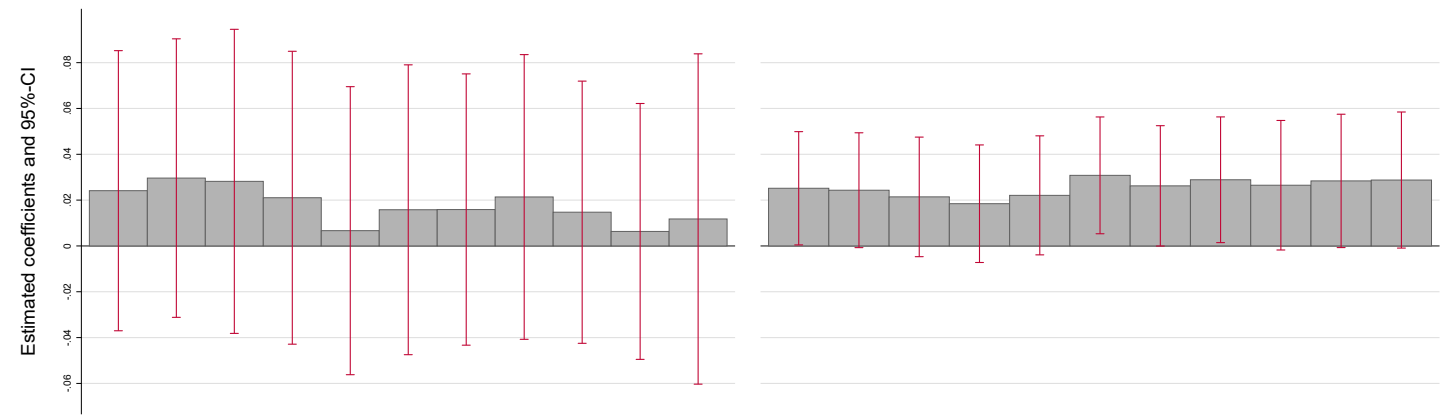

Panel D: Non-disabled

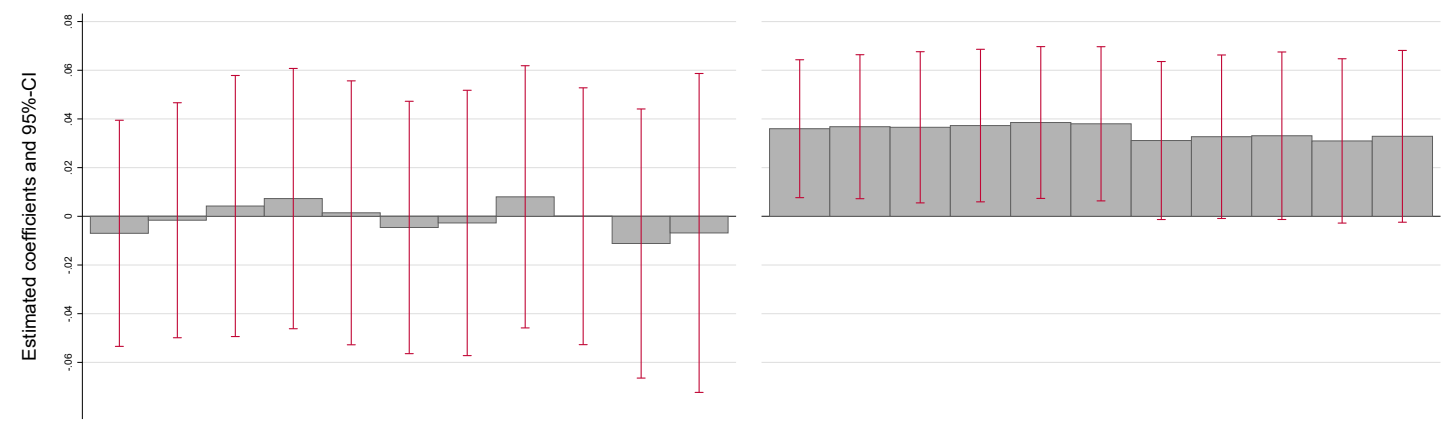

Panel E: Fit for military (boys)
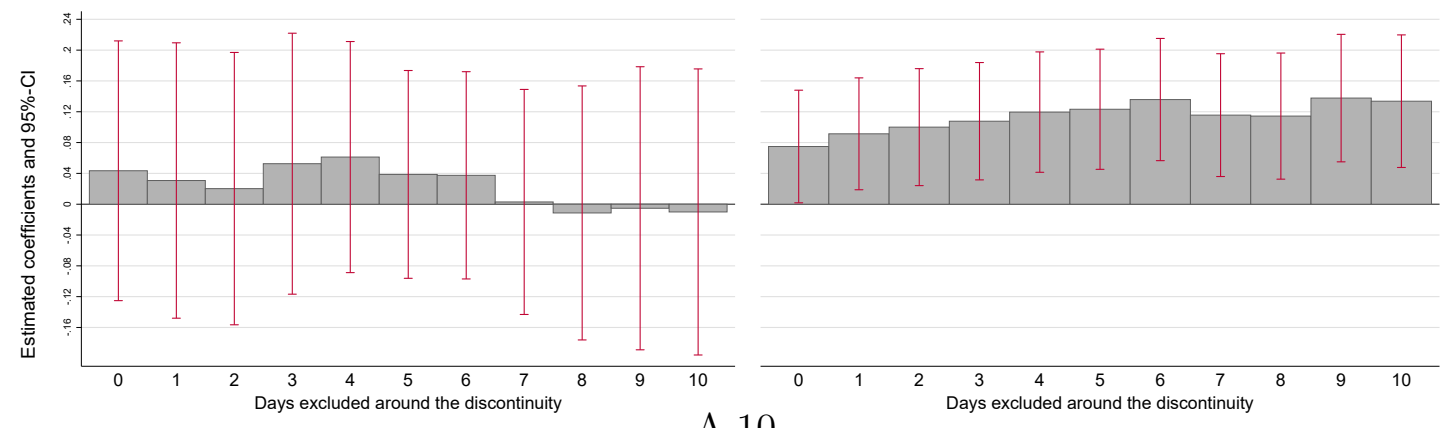
Table A.5: Overview: PL reforms and child outcomes

\begin{tabular}{|c|c|c|c|c|c|}
\hline Study & $\begin{array}{l}\text { Country and year } \\
\text { of reform }\end{array}$ & Content of reform & Assessed child outcomes \& data & Results & Mode of non-parental childcare \\
\hline $\begin{array}{l}\text { Baker and Milligan } \\
(2010)\end{array}$ & $\begin{array}{l}\text { Canada } \\
31 \text { December } 2000\end{array}$ & $\begin{array}{l}\text { Extension of maternity leave bene- } \\
\text { fits from } 25 \text { to } 50 \text { weeks. Extension } \\
\text { of j.p. PL from } 18-70 \text { to at least } 52 \\
\text { weeks in all regions. }\end{array}$ & $\begin{array}{l}\text { Parent-reported measures (tempera- } \\
\text { ment, motor and social development) } \\
\text { at age: } 7 \text { and } 24 \text { months. } \\
\text { Data: survey data (NLSCY) }\end{array}$ & $\begin{array}{l}\text { Small and mostly insignificant re- } \\
\text { sults. } \\
\text { Heterogeneity: Not tested. }\end{array}$ & $\begin{array}{l}\text { Mainly informal care ( } 40 \% \text { for } \\
\text { under- } 2 \text {-year-olds). Formal care } \\
\text { rare }(4 / 6 \% \text { of children younger } \\
\text { than } 1 / 2 \text { year } / \mathrm{s}) \text {. }\end{array}$ \\
\hline $\begin{array}{l}\text { Baker and Milligan } \\
(2015)\end{array}$ & $\begin{array}{l}\text { Canada } \\
31 \text { December } 2000\end{array}$ & see Baker and Milligan (2010) & $\begin{array}{l}\text { Cognitive development (vocabulary, } \\
\text { numbers), parent-reported measures } \\
\text { (eg hyperactivity) at age: } 4 / 5 \text { years. } \\
\text { Data: survey data (NLSCY) }\end{array}$ & $\begin{array}{l}\text { No significant positive effects. Small } \\
\text { negative effects on vocabulary scores. } \\
\text { Heterogeneity: Same across sub- } \\
\text { groups (gender, parental education). }\end{array}$ & see Baker and Milligan (2010) \\
\hline $\begin{array}{lr}\text { Carneiro, } & \text { Løcken } \\
\text { and } & \text { Salvanes } \\
(2015) & \end{array}$ & $\begin{array}{l}\text { Norway } \\
1 \text { July } 1977\end{array}$ & $\begin{array}{l}\text { Introduction of paid PL for } 18 \\
\text { weeks ( } 100 \% \text { income replacement) } \\
\text { Extension of unpaid j.p. PL from } \\
12 \text { weeks to } 12 \text { months }\end{array}$ & $\begin{array}{l}\text { High school dropout, college atten- } \\
\text { dance, earnings at age 30, years } \\
\text { of schooling, IQ (males age 18-19), } \\
\text { teenage pregnancy } \\
\text { Data: Administrative data }\end{array}$ & $\begin{array}{l}\text { Significant positive effects: Reduced } \\
\text { drop-out rates and increased earn- } \\
\text { ings, college attendance, completed } \\
\text { years of schooling and IQ (males) } \\
\text { Heterogeneity: Differential effects by } \\
\text { maternal education, gender, birth or- } \\
\text { der, rural/urban location and dis- } \\
\text { tance to grandparents. }\end{array}$ & $\begin{array}{l}\text { Mainly informal care. Formal } \\
\text { childcare rare (1-2\% for under-2- } \\
\text { year-olds). }\end{array}$ \\
\hline $\begin{array}{l}\text { Dahl, } \quad \text { Løcken, } \\
\text { Mogstad and } \\
\text { Salvanes }(2016)\end{array}$ & $\begin{array}{l}\text { Norway } \\
\text { Six PL reforms: } \\
1 \text { May } 1987- \\
1 \text { April } 1992 .\end{array}$ & $\begin{array}{l}6 \text { extensions of paid PL by } 2 \text { to } 4 \\
\text { weeks each during the first year of } \\
\text { life (at } 100 \% \text { income replacement). }\end{array}$ & $\begin{array}{l}\text { Compulsory exam at end of junior } \\
\text { high school, high school dropout } \\
\text { Data: Administrative data }\end{array}$ & $\begin{array}{l}\text { No significant effects. } \\
\text { Heterogeneity: Not tested. }\end{array}$ & $\begin{array}{l}\text { Mainly informal care. (see } \\
\text { Carneiro et al. 2015) }\end{array}$ \\
\hline $\begin{array}{l}\text { Danzer and Lavy } \\
\text { (2018) }\end{array}$ & $\begin{array}{l}\text { Austria } \\
1 \text { July } 1990\end{array}$ & $\begin{array}{l}\text { Extension of paid+j.p. PL from } \\
\text { child's 1st to 2nd birthday. }\end{array}$ & $\begin{array}{l}\text { Test scores in reading, math and sci- } \\
\text { ence at age } 15 / 16 \text {. } \\
\text { Data: PISA }\end{array}$ & $\begin{array}{l}\text { No significant average effects. } \\
\text { Heterogeneity: Significantly positive } \\
\text { effects for sons of highly educated } \\
\text { mothers. }\end{array}$ & $\begin{array}{l}\text { Mainly informal care. For- } \\
\text { mal childcare for under-3-year- } \\
\text { olds rare }(<3 \%) \text {. }\end{array}$ \\
\hline $\begin{array}{l}\text { Dustmann and } \\
\text { Schönberg (2012) }\end{array}$ & $\begin{array}{l}\text { Germany } \\
\text { Three PL reforms: } \\
\text { 1 May } 1979 \\
\text { 1 January } 1986 \\
\text { 1 January } 1992\end{array}$ & $\begin{array}{l}\text { Extension of paid+j.p. PL from } 2 \\
\text { to } 6 \text { months (flat rate; 1979), from } \\
6 \text { to } 10 \text { months (means-tested; } \\
1986 \text { ) } \\
\text { Extension of unpaid j.p. PL from } \\
18 \text { to } 36 \text { months (1992). }\end{array}$ & $\begin{array}{l}\text { Wages, educational attainment (age } \\
28 / 29 ; 1979 \text { reform), graduation from } \\
\text { academic track }(1986 \text { reform), school } \\
\text { track (age } 14 ; 1992 \text { reform) } \\
\text { Data: Administrative data }\end{array}$ & $\begin{array}{l}\text { No or extremely small effects. Ex- } \\
\text { pansion from } 18 \text { to } 36 \text { months slightly } \\
\text { negative effects. } \\
\text { Heterogeneity: Not tested. }\end{array}$ & $\begin{array}{l}\text { Mainly informal care. Enrolment } \\
\text { in formal care low ( } 5 \% \text { for under } \\
18 \text {-months-olds). }\end{array}$ \\
\hline $\begin{array}{l}\text { Liu and Nordstrom } \\
\text { Skans }(2010)\end{array}$ & $\begin{array}{l}\text { Sweden } \\
1 \text { August } 1988- \\
1 \text { October } 1988\end{array}$ & $\begin{array}{l}\text { Gradual extension of paid PL from } \\
12 \text { to } 15 \text { months (by } 30 \text { days in each } \\
\text { of } 3 \text { consecutive months } 08 / 09 / 10 \\
1988 \text { ). }\end{array}$ & $\begin{array}{l}\text { Test scores during last compul- } \\
\text { sory school year, compulsory school } \\
\text { grades at age } 16 \\
\text { Data: Administrative data }\end{array}$ & $\begin{array}{l}\text { No significant effects. } \\
\text { Heterogeneity: Positive effect for } \\
\text { children from mothers with higher } \\
\text { education. }\end{array}$ & $\begin{array}{l}\text { Mainly formal care }(40-50 \% \text { of } \\
\text { children aged 1-2). Few children } \\
\text { in informal care. }\end{array}$ \\
\hline Rasmussen (2010) & $\begin{array}{l}\text { Denmark } \\
26 \text { March } 1984\end{array}$ & $\begin{array}{l}\text { Extension of paid PL from } 14 \text { to } 20 \\
\text { weeks }\end{array}$ & $\begin{array}{l}\text { High school enrolment, GPA, reading } \\
\text { scores at age } 15 / 16 \\
\text { Data: Administrative data, PISA }\end{array}$ & $\begin{array}{l}\text { No significant effects } \\
\text { Heterogeneity: Same across sub- } \\
\text { groups (gender, parental education). }\end{array}$ & $\begin{array}{l}\text { Mainly formal day care even for } \\
\text { very young children. }\end{array}$ \\
\hline
\end{tabular}

Abbreviations: j.p. - job-protected; NLSCY - National Longitudinal Study of Children and Youth; PL - PL; PISA - Programme for International Student Assessment. 


\section{Table A.6: RD estimates with predetermined characteristics as outcome variables}

\begin{tabular}{|c|c|c|}
\hline & $\begin{array}{l}1989 \& 1990 \\
\text { Linear trends }\end{array}$ & $\begin{array}{c}1989 \& 1990 \\
\text { Quadratic trends }\end{array}$ \\
\hline \multicolumn{3}{|l|}{ Baseline covariates: } \\
\hline Mother is between 15 and 20 years & $\begin{array}{c}-0.008 \\
(0.022)\end{array}$ & $\begin{array}{r}-0.008 \\
(0.022)\end{array}$ \\
\hline Mother is between 21 and 25 years & $\begin{array}{c}-0.042 \\
(0.028)\end{array}$ & $\begin{array}{r}-0.043 \\
(0.028)\end{array}$ \\
\hline Mother is between 26 and 30 years & $\begin{array}{c}0.040 \\
(0.026)\end{array}$ & $\begin{array}{c}0.040 \\
(0.026)\end{array}$ \\
\hline Mother is between 31 and 35 years & $\begin{array}{c}0.012 \\
(0.014)\end{array}$ & $\begin{array}{c}0.011 \\
(0.014)\end{array}$ \\
\hline Mother is between 36 and 45 years & $\begin{array}{r}-0.002 \\
(0.007)\end{array}$ & $\begin{array}{r}-0.002 \\
(0.007)\end{array}$ \\
\hline Mother's socio-economic status is low & $\begin{array}{r}-0.009 \\
(0.032)\end{array}$ & $\begin{array}{c}-0.009 \\
(0.032)\end{array}$ \\
\hline Mother has a foreign background & $\begin{array}{l}0.023^{* *} \\
(0.012)\end{array}$ & $\begin{array}{l}0.024^{* *} \\
(0.012)\end{array}$ \\
\hline Child is female & $\begin{array}{c}0.032 \\
(0.033)\end{array}$ & $\begin{array}{c}0.031 \\
(0.033)\end{array}$ \\
\hline Child was a pre-term birth & $\begin{array}{c}0.006 \\
(0.012)\end{array}$ & $\begin{array}{c}0.005 \\
(0.012)\end{array}$ \\
\hline \multicolumn{3}{|l|}{ Other pre-determined variables: } \\
\hline Low birth weight $(<2500 \mathrm{~g})$ & $\begin{array}{c}-0.003 \\
(0.013)\end{array}$ & $\begin{array}{c}-0.004 \\
(0.013)\end{array}$ \\
\hline Birth weight in dekagram & $\begin{array}{l}1.715 \\
(2.752)\end{array}$ & $\begin{array}{c}1.801 \\
(2.748)\end{array}$ \\
\hline Mother was married at birth & $\begin{array}{c}-0.033 \\
(0.028)\end{array}$ & $\begin{array}{c}-0.033 \\
(0.028)\end{array}$ \\
\hline Mother's highest degree: Compulsory & $\begin{array}{c}-0.021 \\
(0.024)\end{array}$ & $\begin{array}{c}-0.021 \\
(0.024)\end{array}$ \\
\hline Mother's highest degree: Apprenticeship/voc. & $\begin{array}{r}-0.004 \\
(0.027)\end{array}$ & $\begin{array}{c}-0.003 \\
(0.027)\end{array}$ \\
\hline Mother's highest degree: Higher sec./college/uni & $\begin{array}{c}0.021 \\
(0.023)\end{array}$ & $\begin{array}{c}0.021 \\
(0.023)\end{array}$ \\
\hline Pre-birth daily wage & $\begin{array}{c}2.006 \\
(1.283)\end{array}$ & $\begin{array}{c}1.999 \\
(1.280)\end{array}$ \\
\hline
\end{tabular}

Notes: Each coefficient represents a separate regression based on 2SLS estimations, with years on parental leave instrumented by the assignment to the reform. We estimate linear (column 1) and quadratic (column 2) trends in the running variable (birthdate), separately before and after the cutoff including triangular weights. We use a sample of children born in Austria in June/July 1989/1990 and a bandwidth of 30 days, exclude children born \pm 5 days around the cutoff date. Robust standard errors clustered at the community level are shown in parentheses. $*, * *$ and $* * *$ indicate statistical significance at the 10 -percent, 5-percent and 1-percent level. 
Table A.7: Child outcomes by socioeconomic status and sex

\begin{tabular}{|c|c|c|c|c|c|c|}
\hline & \multicolumn{2}{|c|}{ Maternal SES ${ }^{a}$} & \multirow{2}{*}{$\begin{array}{c}\mathrm{P} \text {-value } \\
\Delta^{b}\end{array}$} & \multicolumn{2}{|c|}{ Gender } & \multirow{2}{*}{$\begin{array}{c}\mathrm{P} \text {-value } \\
\Delta^{c}\end{array}$} \\
\hline & Low & High & & Girls & Boys & \\
\hline \multicolumn{7}{|l|}{ Labor market outcomes } \\
\hline Active (age 17) & $\begin{array}{c}0.009 \\
(0.011)\end{array}$ & $\begin{array}{c}0.023^{*} \\
(0.013)\end{array}$ & 0.404 & $\begin{array}{c}0.011 \\
(0.013)\end{array}$ & $\begin{array}{c}0.019 \\
(0.012)\end{array}$ & 0.649 \\
\hline In education (age 17) & $\begin{array}{l}0.010 \\
(0.013)\end{array}$ & $\begin{array}{c}0.024^{*} \\
(0.013)\end{array}$ & 0.366 & $\begin{array}{c}0.007 \\
(0.015)\end{array}$ & $\begin{array}{c}0.022^{*} \\
(0.012)\end{array}$ & 0.378 \\
\hline Active (age 23) & $\begin{array}{c}0.017 \\
(0.025)\end{array}$ & $\begin{array}{c}0.010 \\
(0.027)\end{array}$ & 0.848 & $\begin{array}{c}0.014 \\
(0.027)\end{array}$ & $\begin{array}{c}0.014 \\
(0.027)\end{array}$ & 0.994 \\
\hline In education (age 23) & $\begin{array}{c}-0.025 \\
(0.032)\end{array}$ & $\begin{array}{c}0.047 \\
(0.043)\end{array}$ & 0.186 & $\begin{array}{c}0.035 \\
(0.039)\end{array}$ & $\begin{array}{c}-0.017 \\
(0.035)\end{array}$ & 0.317 \\
\hline Employed (age 23) & $\begin{array}{c}0.057 \\
(0.037)\end{array}$ & $\begin{array}{c}-0.048 \\
(0.047)\end{array}$ & 0.083 & $\begin{array}{c}-0.008 \\
(0.043)\end{array}$ & $\begin{array}{c}0.028 \\
(0.040)\end{array}$ & 0.559 \\
\hline Log wage (age 23) & $\begin{array}{c}-0.000 \\
(0.033)\end{array}$ & $\begin{array}{c}-0.019 \\
(0.048)\end{array}$ & 0.744 & $\begin{array}{c}-0.028 \\
(0.046)\end{array}$ & $\begin{array}{c}0.017 \\
(0.037)\end{array}$ & 0.453 \\
\hline Active (age 17-23) & $\begin{array}{l}0.034^{* *} \\
(0.017)\end{array}$ & $\begin{array}{c}0.017 \\
(0.021)\end{array}$ & 0.542 & $\begin{array}{c}0.017 \\
(0.019)\end{array}$ & $\begin{array}{c}0.033^{*} \\
(0.018)\end{array}$ & 0.554 \\
\hline Always active (age 17-23) & $\begin{array}{c}-0.017 \\
(0.039)\end{array}$ & $\begin{array}{c}0.053 \\
(0.050)\end{array}$ & 0.267 & $\begin{array}{c}0.020 \\
(0.044)\end{array}$ & $\begin{array}{c}0.010 \\
(0.041)\end{array}$ & 0.871 \\
\hline \multicolumn{7}{|l|}{ Health outcomes } \\
\hline Non-disabled & $\begin{array}{c}0.025 \\
(0.020)\end{array}$ & $\begin{array}{c}0.024 \\
(0.021)\end{array}$ & 0.959 & $\begin{array}{c}0.034^{*} \\
(0.019)\end{array}$ & $\begin{array}{c}0.019 \\
(0.020)\end{array}$ & 0.593 \\
\hline Fit for military (boys) & $\begin{array}{l}0.144^{* * *} \\
(0.044)\end{array}$ & $\begin{array}{c}0.047 \\
(0.048)\end{array}$ & 0.114 & & & \\
\hline
\end{tabular}

Notes: Estimation results are based on fully interacted models. Coefficients are based on 2SLS estimations, with years on PL instrumented by the assignment to the reform. We use local linear regressions including triangular weights, a bandwidth of 30 days (excluding children born \pm 5 days around the discontinuity) and separate trends on each side of the discontinuity. We control for the child's sex, low maternal SES, maternal age groups, whether the mother was born abroad, and whether the child was a pre-term birth. Standard errors (shown in parentheses) are clustered at the community level. $*, * *$ and $* * *$ indicate statistical significance at the 10-percent, 5-percent and 1-percent level. ${ }^{a}$ Maternal socioeconomic status is based on maternal education and pre-birth earnings: Low SES mothers have either compulsory schooling or apprenticeship training/intermediate vocational school plus below median pre-birth earnings; high SES mothers have either apprenticeship training/intermediate vocational school plus above median pre-birth earnings or at least higher secondary education). ${ }^{b}$ Prob $>F($ chi2) of difference in coefficients between children of mothers with low/high socioeconomic status. ${ }^{c}$ Prob $>F($ chi2) of difference in coefficients between girls and boys. 
Table A.8: Child outcomes by availability of nursery \& socioeconomic status

\begin{tabular}{|c|c|c|c|c|c|c|}
\hline & \multicolumn{3}{|c|}{ Communities with nursery } & \multicolumn{3}{|c|}{ Communities w/o nursery } \\
\hline & Low $\mathrm{SES}^{a}$ & High SES ${ }^{a}$ & $\mathrm{P}$-value $\Delta^{b}$ & Low SES ${ }^{a}$ & High $\mathrm{SES}^{a}$ & $\mathrm{P}$-value $\Delta^{b}$ \\
\hline Active (age 17) & $\begin{array}{c}0.001 \\
(0.027)\end{array}$ & $\begin{array}{c}0.030 \\
(0.031)\end{array}$ & 0.427 & $\begin{array}{c}0.020 \\
(0.013)\end{array}$ & $\begin{array}{c}0.014 \\
(0.012)\end{array}$ & 0.757 \\
\hline Active (age 23) & $\begin{array}{c}0.026 \\
(0.053)\end{array}$ & $\begin{array}{c}-0.063 \\
(0.052)\end{array}$ & 0.237 & $\begin{array}{c}0.045 \\
(0.030)\end{array}$ & $\begin{array}{c}0.016 \\
(0.028)\end{array}$ & 0.474 \\
\hline Non-disabled & $\begin{array}{c}0.036 \\
(0.046)\end{array}$ & $\begin{array}{r}-0.042 \\
(0.040)\end{array}$ & 0.253 & $\begin{array}{c}0.059^{* *} \\
(0.023)\end{array}$ & $\begin{array}{c}0.023 \\
(0.022)\end{array}$ & 0.245 \\
\hline Fit for military (boys) & $\begin{array}{c}0.111 \\
(0.083)\end{array}$ & $\begin{array}{c}-0.034 \\
(0.087)\end{array}$ & 0.130 & $\begin{array}{c}0.082 \\
(0.059)\end{array}$ & $\begin{array}{l}0.158^{* * *} \\
(0.052)\end{array}$ & 0.326 \\
\hline
\end{tabular}

Notes: Estimation results are based on fully interacted models, estimated separately for mothers living in communities with and without nursery. Coefficients are based on 2SLS estimations, with years on PL instrumented by the assignment to the reform (both interacted with indicators for mothers with low and high SES). We use local linear regressions including triangular weights and separate linear trends on each side of the discontinuity. We use a bandwidth of 30 days, exclude children born \pm 5 days around the cutoff date, and control for the child's sex, low maternal SES, maternal age groups, whether the mother was born abroad, and whether the child was a pre-term birth. Standard errors (shown in parentheses) are clustered at the community level. *, ** and *** indicate statistical significance at the 10-percent, 5-percent and 1-percent level. ${ }^{a}$ Maternal socioeconomic status is based on maternal education and pre-birth earnings (low: compulsory, apprenticeship training or intermediate vocational school plus below median pre-birth earnings, missing education; high: apprenticeship training or intermediate vocational school plus above median pre-birth earnings and at least higher secondary education). ${ }^{b}$ Prob $>\mathrm{F}(\mathrm{chi} 2)$ of difference in coefficients between mothers with high and low SES. 
Table A.9: Sensitivity: Child outcomes by availability of nursery \& maternal work propensity

\begin{tabular}{|c|c|c|c|c|c|c|}
\hline & \multicolumn{3}{|c|}{ Low work propensity ${ }^{a}$} & \multicolumn{3}{|c|}{ High work propensity ${ }^{a}$} \\
\hline & $\begin{array}{l}\text { Communities } \\
\text { with nursery }\end{array}$ & $\begin{array}{l}\text { Communities } \\
\text { w/o nursery }\end{array}$ & $\begin{array}{c}\mathrm{P} \text {-value } \\
\Delta^{b}\end{array}$ & $\begin{array}{l}\text { Communities } \\
\text { with nursery }\end{array}$ & $\begin{array}{l}\text { Communities } \\
\text { w/o nursery }\end{array}$ & $\begin{array}{c}\mathrm{P} \text {-value } \\
\Delta^{b}\end{array}$ \\
\hline \multicolumn{7}{|l|}{ No covariates ${ }^{c}$} \\
\hline Active (age 17) & $\begin{array}{c}0.027 \\
(0.030)\end{array}$ & $\begin{array}{c}0.007 \\
(0.011)\end{array}$ & 0.539 & $\begin{array}{c}0.005 \\
(0.033)\end{array}$ & $\begin{array}{l}0.028^{* *} \\
(0.013)\end{array}$ & 0.512 \\
\hline Active (age 23) & $\begin{array}{c}0.020 \\
(0.050)\end{array}$ & $\begin{array}{c}-0.009 \\
(0.029)\end{array}$ & 0.618 & $\begin{array}{c}-0.068 \\
(0.056)\end{array}$ & $\begin{array}{l}0.079 * * * \\
(0.030)\end{array}$ & 0.021 \\
\hline Active (age 17-23) & $\begin{array}{c}0.003 \\
(0.034)\end{array}$ & $\begin{array}{c}0.018 \\
(0.017)\end{array}$ & 0.698 & $\begin{array}{c}0.018 \\
(0.047)\end{array}$ & $\begin{array}{l}0.048^{* *} \\
(0.020)\end{array}$ & 0.555 \\
\hline Non-disabled & $\begin{array}{c}0.020 \\
(0.051)\end{array}$ & $\begin{array}{c}0.027 \\
(0.020)\end{array}$ & 0.896 & $\begin{array}{c}-0.025 \\
(0.029)\end{array}$ & $\begin{array}{l}0.055^{* *} \\
(0.026)\end{array}$ & 0.039 \\
\hline Fit for military (boys) & $\begin{array}{c}0.101 \\
(0.113)\end{array}$ & $\begin{array}{l}0.075 \\
(0.053)\end{array}$ & 0.838 & $\begin{array}{c}-0.021 \\
(0.085)\end{array}$ & $\begin{array}{l}0.178^{* * *} \\
(0.061)\end{array}$ & 0.058 \\
\hline \multicolumn{7}{|l|}{ More covariates ${ }^{d}$} \\
\hline Active (age 17) & $\begin{array}{c}0.031 \\
(0.029)\end{array}$ & $\begin{array}{c}0.006 \\
(0.011)\end{array}$ & 0.420 & $\begin{array}{c}0.003 \\
(0.036)\end{array}$ & $\begin{array}{l}0.027^{* *} \\
(0.013)\end{array}$ & 0.549 \\
\hline Active (age 23) & $\begin{array}{l}0.020 \\
(0.055)\end{array}$ & $\begin{array}{c}-0.012 \\
(0.028)\end{array}$ & 0.607 & $\begin{array}{c}-0.065 \\
(0.060)\end{array}$ & $\begin{array}{l}0.070^{* *} \\
(0.029)\end{array}$ & 0.042 \\
\hline Active (age 17-23) & $\begin{array}{c}0.010 \\
(0.034)\end{array}$ & $\begin{array}{l}0.016 \\
(0.017)\end{array}$ & 0.890 & $\begin{array}{c}0.027 \\
(0.050)\end{array}$ & $\begin{array}{l}0.049^{* * *} \\
(0.019)\end{array}$ & 0.672 \\
\hline Non-disabled & $\begin{array}{c}0.019 \\
(0.051)\end{array}$ & $\begin{array}{c}0.025 \\
(0.020)\end{array}$ & 0.920 & $\begin{array}{c}-0.026 \\
(0.030)\end{array}$ & $\begin{array}{c}0.048^{*} \\
(0.025)\end{array}$ & 0.061 \\
\hline Fit for military (boys) & $\begin{array}{l}0.126 \\
(0.114)\end{array}$ & $\begin{array}{c}0.072 \\
(0.053)\end{array}$ & 0.663 & $\begin{array}{c}-0.052 \\
(0.075)\end{array}$ & $\begin{array}{l}0.177^{* * *} \\
(0.060)\end{array}$ & 0.017 \\
\hline \multicolumn{7}{|c|}{ Community-level covariates ${ }^{e}$} \\
\hline Active (age 17) & $\begin{array}{c}0.027 \\
(0.028)\end{array}$ & $\begin{array}{c}0.007 \\
(0.011)\end{array}$ & 0.489 & $\begin{array}{c}0.011 \\
(0.036)\end{array}$ & $\begin{array}{l}0.027^{* *} \\
(0.013)\end{array}$ & 0.658 \\
\hline Active (age 23) & $\begin{array}{l}0.007 \\
(0.053)\end{array}$ & $\begin{array}{c}-0.009 \\
(0.028)\end{array}$ & 0.788 & $\begin{array}{c}-0.057 \\
(0.056)\end{array}$ & $\begin{array}{l}0.079^{* * *} \\
(0.030)\end{array}$ & 0.032 \\
\hline Active (age 17-23) & $\begin{array}{c}0.010 \\
(0.032)\end{array}$ & $\begin{array}{l}0.016 \\
(0.017)\end{array}$ & 0.861 & $\begin{array}{c}0.027 \\
(0.047)\end{array}$ & $\begin{array}{l}0.052^{* * *} \\
(0.019)\end{array}$ & 0.626 \\
\hline Non-disabled & $\begin{array}{c}0.023 \\
(0.050)\end{array}$ & $\begin{array}{c}0.026 \\
(0.020)\end{array}$ & 0.964 & $\begin{array}{c}-0.018 \\
(0.030)\end{array}$ & $\begin{array}{c}0.050^{*} \\
(0.026)\end{array}$ & 0.081 \\
\hline Fit for military (boys) & $\begin{array}{l}0.126 \\
(0.113)\end{array}$ & $\begin{array}{c}0.071 \\
(0.053)\end{array}$ & 0.661 & $\begin{array}{c}-0.057 \\
(0.081)\end{array}$ & $\begin{array}{l}0.178^{* * *} \\
(0.059)\end{array}$ & 0.019 \\
\hline \multicolumn{7}{|l|}{ Quadratic trends ${ }^{f}$} \\
\hline Active (age 17) & $\begin{array}{c}0.031 \\
(0.029)\end{array}$ & $\begin{array}{l}0.006 \\
(0.011)\end{array}$ & 0.418 & $\begin{array}{c}0.002 \\
(0.036)\end{array}$ & $\begin{array}{l}0.027^{* *} \\
(0.013)\end{array}$ & 0.526 \\
\hline Active (age 23) & $\begin{array}{l}0.020 \\
(0.055)\end{array}$ & $\begin{array}{c}-0.013 \\
(0.028)\end{array}$ & 0.593 & $\begin{array}{c}-0.061 \\
(0.059)\end{array}$ & $\begin{array}{l}0.070^{* *} \\
(0.029)\end{array}$ & 0.047 \\
\hline Active (age 17-23) & $\begin{array}{c}0.010 \\
(0.034)\end{array}$ & $\begin{array}{l}0.015 \\
(0.017)\end{array}$ & 0.889 & $\begin{array}{c}0.026 \\
(0.050)\end{array}$ & $\begin{array}{l}0.050^{* * *} \\
(0.019)\end{array}$ & 0.659 \\
\hline Non-disabled & $\begin{array}{l}0.020 \\
(0.050)\end{array}$ & $\begin{array}{c}0.024 \\
(0.020)\end{array}$ & 0.936 & $\begin{array}{c}-0.027 \\
(0.030)\end{array}$ & $\begin{array}{c}0.049^{*} \\
(0.025)\end{array}$ & 0.056 \\
\hline Fit for military (boys) & $\begin{array}{c}0.126 \\
(0.113)\end{array}$ & $\begin{array}{c}0.071 \\
(0.053)\end{array}$ & 0.663 & $\begin{array}{c}-0.051 \\
(0.075)\end{array}$ & $\begin{array}{l}0.178^{* * *} \\
(0.059)\end{array}$ & 0.017 \\
\hline
\end{tabular}

to be continued on next page 
Table A8 continued

\begin{tabular}{|c|c|c|c|c|c|c|}
\hline & \multicolumn{3}{|c|}{ Low work propensity ${ }^{a}$} & \multicolumn{3}{|c|}{ High work propensity ${ }^{a}$} \\
\hline & $\begin{array}{l}\text { Communities } \\
\text { with nursery }\end{array}$ & $\begin{array}{l}\text { Communities } \\
\text { w/o nursery }\end{array}$ & $\begin{array}{c}\text { P-value } \\
\Delta^{b}\end{array}$ & $\begin{array}{l}\text { Communities } \\
\text { with nursery }\end{array}$ & $\begin{array}{l}\text { Communities } \\
\text { w/o nursery }\end{array}$ & $\begin{array}{c}\text { P-value } \\
\Delta^{b}\end{array}$ \\
\hline \multicolumn{7}{|l|}{ Exclude migrants ${ }^{g}$} \\
\hline Active (age 17) & $\begin{array}{c}0.026 \\
(0.028)\end{array}$ & $\begin{array}{c}0.006 \\
(0.011)\end{array}$ & 0.500 & $\begin{array}{c}-0.019 \\
(0.028)\end{array}$ & $\begin{array}{l}0.032^{* *} \\
(0.014)\end{array}$ & 0.095 \\
\hline Active (age 23) & $\begin{array}{c}0.004 \\
(0.055)\end{array}$ & $\begin{array}{c}-0.010 \\
(0.029)\end{array}$ & 0.815 & $\begin{array}{c}-0.092^{*} \\
(0.055)\end{array}$ & $\begin{array}{l}0.064^{* *} \\
(0.031)\end{array}$ & 0.014 \\
\hline Active (age 17-23) & $\begin{array}{c}-0.003 \\
(0.034)\end{array}$ & $\begin{array}{c}0.014 \\
(0.017)\end{array}$ & 0.658 & $\begin{array}{c}0.015 \\
(0.046)\end{array}$ & $\begin{array}{l}0.042^{* *} \\
(0.020)\end{array}$ & 0.588 \\
\hline Non-disabled & $\begin{array}{c}0.017 \\
(0.050)\end{array}$ & $\begin{array}{c}0.017 \\
(0.020)\end{array}$ & 0.996 & $\begin{array}{c}-0.041 \\
(0.031)\end{array}$ & $\begin{array}{l}0.067^{* *} \\
(0.026)\end{array}$ & 0.008 \\
\hline Fit for military (boys) & $\begin{array}{c}0.107 \\
(0.110)\end{array}$ & $\begin{array}{c}0.071 \\
(0.053)\end{array}$ & 0.768 & $\begin{array}{c}-0.111 \\
(0.089)\end{array}$ & $\begin{array}{l}0.184^{* * *} \\
(0.063)\end{array}$ & 0.007 \\
\hline \multicolumn{7}{|l|}{ Bandwidth of 61 days $^{h}$} \\
\hline Active (age 17) & $\begin{array}{c}0.009 \\
(0.026)\end{array}$ & $\begin{array}{c}-0.001 \\
(0.008)\end{array}$ & 0.711 & $\begin{array}{c}0.001 \\
(0.021)\end{array}$ & $\begin{array}{l}0.021^{* *} \\
(0.009)\end{array}$ & 0.363 \\
\hline Active (age 23) & $\begin{array}{c}-0.022 \\
(0.033)\end{array}$ & $\begin{array}{c}-0.009 \\
(0.019)\end{array}$ & 0.734 & $\begin{array}{c}-0.015 \\
(0.037)\end{array}$ & $\begin{array}{l}0.053^{* *} \\
(0.021)\end{array}$ & 0.110 \\
\hline Active (age 17-23) & $\begin{array}{c}-0.018 \\
(0.024)\end{array}$ & $\begin{array}{c}0.007 \\
(0.012)\end{array}$ & 0.350 & $\begin{array}{c}0.022 \\
(0.026)\end{array}$ & $\begin{array}{l}0.033^{* *} \\
(0.014)\end{array}$ & 0.699 \\
\hline Non-disabled & $\begin{array}{c}-0.009 \\
(0.028)\end{array}$ & $\begin{array}{c}0.002 \\
(0.013)\end{array}$ & 0.714 & $\begin{array}{c}-0.030^{*} \\
(0.018)\end{array}$ & $\begin{array}{l}0.056^{* * *} \\
(0.016)\end{array}$ & 0.000 \\
\hline Fit for military (boys) & $\begin{array}{c}0.064 \\
(0.076)\end{array}$ & $\begin{array}{l}0.073^{* *} \\
(0.036)\end{array}$ & 0.915 & $\begin{array}{c}-0.076 \\
(0.073)\end{array}$ & $\begin{array}{l}0.105^{* * *} \\
(0.040)\end{array}$ & 0.031 \\
\hline \multicolumn{7}{|c|}{ Employed at least 180 days $^{i}$} \\
\hline Active (age 17) & $\begin{array}{c}0.046^{*} \\
(0.025)\end{array}$ & $\begin{array}{c}0.010 \\
(0.012)\end{array}$ & 0.191 & $\begin{array}{c}-0.013 \\
(0.036)\end{array}$ & $\begin{array}{c}0.023^{*} \\
(0.013)\end{array}$ & 0.348 \\
\hline Active (age 23) & $\begin{array}{c}0.022 \\
(0.055)\end{array}$ & $\begin{array}{c}0.019 \\
(0.028)\end{array}$ & 0.956 & $\begin{array}{c}-0.073 \\
(0.066)\end{array}$ & $\begin{array}{c}0.040 \\
(0.032)\end{array}$ & 0.123 \\
\hline Active (age 17-23) & $\begin{array}{c}0.044 \\
(0.036)\end{array}$ & $\begin{array}{c}0.010 \\
(0.017)\end{array}$ & 0.405 & $\begin{array}{c}-0.008 \\
(0.049)\end{array}$ & $\begin{array}{l}0.056^{* * *} \\
(0.019)\end{array}$ & 0.215 \\
\hline Non-disabled & $\begin{array}{c}0.012 \\
(0.042)\end{array}$ & $\begin{array}{c}0.022 \\
(0.021)\end{array}$ & 0.832 & $\begin{array}{c}-0.024 \\
(0.034)\end{array}$ & $\begin{array}{l}0.058^{* *} \\
(0.025)\end{array}$ & 0.053 \\
\hline Fit for military (boys) & $\begin{array}{c}0.062 \\
(0.079)\end{array}$ & $\begin{array}{c}0.094^{*} \\
(0.054)\end{array}$ & 0.738 & $\begin{array}{c}-0.012 \\
(0.079)\end{array}$ & $\begin{array}{l}0.158^{* * *} \\
(0.060)\end{array}$ & 0.086 \\
\hline
\end{tabular}

Notes: Estimation results are based on fully interacted models, estimated separately for mothers with low and high work propensity. Coefficients are based on 2SLS estimations, with years on parental leave instrumented by the assignment to the reform (both interacted with indicators for communities with and without nursery). We use local linear regressions including triangular weights, a bandwidth of 30 days (excluding children born \pm 5 days around the cutoff date) and separate trends on each side of the discontinuity. Unless otherwise indicated, we control for a vector of pre-determined variables $\mathbf{x}$ (child's sex, low maternal SES, maternal age groups, whether the mother was born abroad, and whether the child was a pre-term birth). Standard errors (shown in parentheses) are clustered at the community-level. *, $* *$ and $* * *$ indicate statistical significance at the 10-percent, 5-percent and 1-percent level. ${ }^{a}$ Maternal characteristics indicate a low/high propensity of being employed $>0$ days in the second year after childbirth, low/high according to median prediction $(0.51) .{ }^{b}$ Prob $>\mathrm{F}$ (chi2) of difference in coefficients between mothers living in communities with and without nursery based on fully interacted regressions. ${ }^{c}$ Excludes vector of predetermined covariates $\mathbf{x}$.

${ }^{d}$ Additional covariates: maternal daily real wage (mean over last 2 years before child birth), maternal occupation (white-collar/civil servant, Additional covariates: maternal daily real wage (mean over last 2 years before child birth), maternal occupation (white-collar/civil servant,
blue-collar, self-employed/farmer), whether the mother was married, maternal education (6 indicators), maternal religious denomination ( 5 indicators), province ( 8 indicators), and whether the child had low birth weight. ${ }^{e}$ Additional community-level covariates: population size, population density, share of catholics, share of votes for conservative parties, share of married, share of pop. betw. 0 and 5 years, share of pop. betw. 0 and 15 years, female employment rate, female fulltime employment rate, availability of a higher secondary school and number of classes in higher secondary school. ${ }^{f}$ Quadratic trends in the running variable. ${ }^{g}$ Excludes foreign-born mothers from the sample. ${ }^{h}$ Bandwidth of 61 days on each side of the discontinuity (excluding children born \pm 5 days around the cutoff date) ${ }^{i}$ Maternal characteristics indicate a low/high propensity of being employed $\geq 180$ days in the second year after childbirth, low/high according to median prediction (0.34). 
Table A.10: Child outcomes by propensity of child care availability in communities w/o nursery

\begin{tabular}{|c|c|c|c|c|c|c|}
\hline \multirow[b]{2}{*}{ Propensity score ${ }^{b}$} & \multicolumn{3}{|c|}{ Low work propensity ${ }^{a}$} & \multicolumn{3}{|c|}{ High work propensity ${ }^{a}$} \\
\hline & Below median & Above median & $\mathrm{P}$-value $\Delta^{c}$ & Below median & Above median & $\mathrm{P}$-value $\Delta^{c}$ \\
\hline Active (age 17) & $\begin{array}{c}0.002 \\
(0.016)\end{array}$ & $\begin{array}{c}0.011 \\
(0.014)\end{array}$ & 0.664 & $\begin{array}{c}0.018 \\
(0.018)\end{array}$ & $\begin{array}{l}0.040^{* *} \\
(0.020)\end{array}$ & 0.405 \\
\hline Active (age 23) & $\begin{array}{c}-0.048 \\
(0.045)\end{array}$ & $\begin{array}{c}0.025 \\
(0.036)\end{array}$ & 0.203 & $\begin{array}{l}0.111^{* *} \\
(0.045)\end{array}$ & $\begin{array}{c}0.048 \\
(0.040)\end{array}$ & 0.292 \\
\hline Active (age 17-23) & $\begin{array}{c}0.024 \\
(0.027)\end{array}$ & $\begin{array}{c}0.008 \\
(0.022)\end{array}$ & 0.647 & $\begin{array}{c}0.037 \\
(0.027)\end{array}$ & $\begin{array}{c}0.066^{* *} \\
(0.028)\end{array}$ & 0.453 \\
\hline Non-disabled & $\begin{array}{l}0.069^{* *} \\
(0.029)\end{array}$ & $\begin{array}{c}-0.008 \\
(0.028)\end{array}$ & 0.052 & $\begin{array}{c}0.042 \\
(0.034)\end{array}$ & $\begin{array}{c}0.058 \\
(0.040)\end{array}$ & 0.763 \\
\hline Fit for military (boys) & $\begin{array}{c}0.054 \\
(0.081)\end{array}$ & $\begin{array}{c}0.082 \\
(0.071)\end{array}$ & 0.794 & $\begin{array}{l}0.196^{* *} \\
(0.083)\end{array}$ & $\begin{array}{c}0.188^{* *} \\
(0.086)\end{array}$ & 0.950 \\
\hline
\end{tabular}

Notes: Estimation results are based on fully interacted models, estimated separately for mothers with low and high work propensity. Coefficients are based on 2SLS estimations, with years on parental leave instrumented by the assignment to the reform (both interacted with indicators for low and high values of the respective community characteristic). We use local linear regressions including triangular weights, a bandwidth of 30 days (excluding children born \pm 5 days around the cutoff date) and separate trends on each side of the discontinuity. Unless otherwise indicated, we control for a vector of pre-determined variables $\mathbf{x}$ (child's sex, low maternal SES, maternal age groups, whether the mother was born abroad, and whether the child was a pre-term birth). Standard errors (shown in parentheses) are clustered at the community-level. * $* *$ and $* * *$ indicate statistical significance at the 10-percent, 5-percent and 1-percent level. ${ }^{a}$ Maternal characteristics indicate a high/low propensity of being employed $>0$ days in the second year after childbirth. ${ }^{b}$ Communities (w/o nurseries) are stratified based on the estimated propensity of formal child care availability using the overall sample of communities with and w/o nurseries. ${ }^{c}$ Prob $>F(c h i 2)$ of difference in coefficients between mothers living in communities with low/high value of the respective community characteristic. 
Table A.11: Further child

\begin{tabular}{|c|c|c|c|c|}
\hline & $\begin{array}{c}\text { All } \\
\text { communities }\end{array}$ & $\begin{array}{l}\text { Communities } \\
\text { with nursery }\end{array}$ & $\begin{array}{l}\text { Communities } \\
\text { w/o nursery }\end{array}$ & $\begin{array}{c}\mathrm{P} \text {-value } \\
\quad \Delta^{a}\end{array}$ \\
\hline \multicolumn{5}{|l|}{ Further child $^{b}$} \\
\hline 1 year after birth & $\begin{array}{c}-0.003 \\
(0.005)\end{array}$ & $\begin{array}{c}-0.002 \\
(0.007)\end{array}$ & $\begin{array}{c}-0.004 \\
(0.006)\end{array}$ & 0.774 \\
\hline 2 years after birth & $\begin{array}{c}0.039^{*} \\
(0.023)\end{array}$ & $\begin{array}{c}0.004 \\
(0.039)\end{array}$ & $\begin{array}{c}0.052^{*} \\
(0.028)\end{array}$ & 0.319 \\
\hline 3 years after birth & $\begin{array}{c}0.043 \\
(0.028)\end{array}$ & $\begin{array}{c}0.078^{*} \\
(0.046)\end{array}$ & $\begin{array}{c}0.030 \\
(0.034)\end{array}$ & 0.406 \\
\hline 4 years after birth & $\begin{array}{l}0.036 \\
(0.030)\end{array}$ & $\begin{array}{c}0.054 \\
(0.052)\end{array}$ & $\begin{array}{c}0.032 \\
(0.036)\end{array}$ & 0.729 \\
\hline 5 years after birth & $\begin{array}{c}0.025 \\
(0.031)\end{array}$ & $\begin{array}{l}0.051 \\
(0.057)\end{array}$ & $\begin{array}{l}0.020 \\
(0.035)\end{array}$ & 0.645 \\
\hline 6 years after birth & $\begin{array}{c}0.031 \\
(0.031)\end{array}$ & $\begin{array}{c}0.024 \\
(0.054)\end{array}$ & $\begin{array}{l}0.040 \\
(0.036)\end{array}$ & 0.801 \\
\hline 7 years after birth & $\begin{array}{c}0.017 \\
(0.031)\end{array}$ & $\begin{array}{l}0.026 \\
(0.053)\end{array}$ & $\begin{array}{c}0.021 \\
(0.036)\end{array}$ & 0.942 \\
\hline 8 years after birth & $\begin{array}{c}0.035 \\
(0.029)\end{array}$ & $\begin{array}{l}0.030 \\
(0.050)\end{array}$ & $\begin{array}{c}0.045 \\
(0.034)\end{array}$ & 0.809 \\
\hline 9 years after birth & $\begin{array}{c}0.041 \\
(0.029)\end{array}$ & $\begin{array}{c}0.043 \\
(0.052)\end{array}$ & $\begin{array}{c}0.049 \\
(0.034)\end{array}$ & 0.923 \\
\hline 10 years after birth & $\begin{array}{c}0.039 \\
(0.028)\end{array}$ & $\begin{array}{l}0.049 \\
(0.047)\end{array}$ & $\begin{array}{c}0.043 \\
(0.033)\end{array}$ & 0.917 \\
\hline 11 years after birth & $\begin{array}{c}0.038 \\
(0.028)\end{array}$ & $\begin{array}{l}0.040 \\
(0.046)\end{array}$ & $\begin{array}{c}0.045 \\
(0.032)\end{array}$ & 0.919 \\
\hline 12 years after birth & $\begin{array}{c}0.032 \\
(0.027)\end{array}$ & $\begin{array}{c}0.045 \\
(0.042)\end{array}$ & $\begin{array}{c}0.035 \\
(0.032)\end{array}$ & 0.839 \\
\hline 13 years after birth & $\begin{array}{c}0.036 \\
(0.026)\end{array}$ & $\begin{array}{c}0.063 \\
(0.042)\end{array}$ & $\begin{array}{c}0.033 \\
(0.031)\end{array}$ & 0.559 \\
\hline 14 years after birth & $\begin{array}{c}0.039 \\
(0.026)\end{array}$ & $\begin{array}{c}0.061 \\
(0.044)\end{array}$ & $\begin{array}{l}0.038 \\
(0.031)\end{array}$ & 0.670 \\
\hline 15 years after birth & $\begin{array}{c}0.038 \\
(0.026)\end{array}$ & $\begin{array}{l}0.059 \\
(0.044)\end{array}$ & $\begin{array}{l}0.038 \\
(0.031)\end{array}$ & 0.692 \\
\hline 16 years after birth & $\begin{array}{l}0.040 \\
(0.026)\end{array}$ & $\begin{array}{c}0.062 \\
(0.044)\end{array}$ & $\begin{array}{c}0.039 \\
(0.031)\end{array}$ & 0.663 \\
\hline 17 years after birth & $\begin{array}{c}0.043 \\
(0.026)\end{array}$ & $\begin{array}{c}0.068 \\
(0.042)\end{array}$ & $\begin{array}{c}0.040 \\
(0.031)\end{array}$ & 0.593 \\
\hline
\end{tabular}

Notes: Each row represents two separate regressions. Estimation results by availability of nursery are based on fully interacted models. Coefficients based on 2SLS estimations, with years on parental leave instrumented by the assignment to the reform. We use local linear regressions including triangular weights and separate trends before and after the cutoff. We use a sample of children born in Austria in June/July 1989/1990, a bandwidth of 30 days, exclude children born \pm 5 days around the cutoff date, and control for the child's sex, low maternal SES, maternal age groups, whether the mother was born abroad, whether the child was a pre-term birth and linear trends in the running variable (date of birth). Robust standard errors clustered at the community level are shown in parentheses. ${ }^{*}, * *$ and $* * *$ indicate statistical significance at the 10 -percent 5-percent and 1-percent level. ${ }^{a}$ Prob $>$ chi2 of difference in coefficients between communities with and w/o nursery. ${ }^{b}$ The mother has a further child at the first child's birthday in each year. 
Table A.12: Number of children

\begin{tabular}{|c|c|c|c|c|}
\hline & $\begin{array}{c}\text { All } \\
\text { communities }\end{array}$ & $\begin{array}{l}\text { Communities } \\
\text { with nursery }\end{array}$ & $\begin{array}{l}\text { Communities } \\
\text { w/o nursery }\end{array}$ & $\begin{array}{c}\text { P-value } \\
\Delta^{a}\end{array}$ \\
\hline \multicolumn{5}{|l|}{ Number of children ${ }^{b}$} \\
\hline 1 year after birth & $\begin{array}{c}-0.004 \\
(0.005)\end{array}$ & $\begin{array}{c}-0.006 \\
(0.009)\end{array}$ & $\begin{array}{c}-0.004 \\
(0.006)\end{array}$ & 0.896 \\
\hline 2 years after birth & $\begin{array}{c}0.037 \\
(0.024)\end{array}$ & $\begin{array}{r}-0.008 \\
(0.042)\end{array}$ & $\begin{array}{c}0.054^{*} \\
(0.028)\end{array}$ & 0.222 \\
\hline 3 years after birth & $\begin{array}{c}0.046 \\
(0.030)\end{array}$ & $\begin{array}{c}0.059 \\
(0.049)\end{array}$ & $\begin{array}{c}0.042 \\
(0.036)\end{array}$ & 0.775 \\
\hline 4 years after birth & $\begin{array}{c}0.039 \\
(0.034)\end{array}$ & $\begin{array}{c}0.042 \\
(0.060)\end{array}$ & $\begin{array}{c}0.042 \\
(0.040)\end{array}$ & 0.994 \\
\hline 5 years after birth & $\begin{array}{c}0.043 \\
(0.038)\end{array}$ & $\begin{array}{c}0.064 \\
(0.071)\end{array}$ & $\begin{array}{c}0.040 \\
(0.044)\end{array}$ & 0.779 \\
\hline 6 years after birth & $\begin{array}{c}0.045 \\
(0.040)\end{array}$ & $\begin{array}{c}0.047 \\
(0.069)\end{array}$ & $\begin{array}{c}0.051 \\
(0.048)\end{array}$ & 0.956 \\
\hline 7 years after birth & $\begin{array}{c}0.024 \\
(0.041)\end{array}$ & $\begin{array}{c}0.059 \\
(0.071)\end{array}$ & $\begin{array}{c}0.018 \\
(0.050)\end{array}$ & 0.633 \\
\hline 8 years after birth & $\begin{array}{c}0.029 \\
(0.043)\end{array}$ & $\begin{array}{c}0.059 \\
(0.072)\end{array}$ & $\begin{array}{c}0.026 \\
(0.052)\end{array}$ & 0.705 \\
\hline 9 years after birth & $\begin{array}{c}0.032 \\
(0.045)\end{array}$ & $\begin{array}{c}0.085 \\
(0.076)\end{array}$ & $\begin{array}{c}0.020 \\
(0.053)\end{array}$ & 0.483 \\
\hline 10 years after birth & $\begin{array}{c}0.025 \\
(0.046)\end{array}$ & $\begin{array}{c}0.089 \\
(0.077)\end{array}$ & $\begin{array}{c}0.009 \\
(0.055)\end{array}$ & 0.395 \\
\hline 11 years after birth & $\begin{array}{c}0.027 \\
(0.048)\end{array}$ & $\begin{array}{c}0.083 \\
(0.088)\end{array}$ & $\begin{array}{c}0.012 \\
(0.056)\end{array}$ & 0.497 \\
\hline 12 years after birth & $\begin{array}{c}0.012 \\
(0.048)\end{array}$ & $\begin{array}{c}0.083 \\
(0.087)\end{array}$ & $\begin{array}{c}-0.007 \\
(0.058)\end{array}$ & 0.384 \\
\hline 13 years after birth & $\begin{array}{c}0.019 \\
(0.050)\end{array}$ & $\begin{array}{c}0.114 \\
(0.095)\end{array}$ & $\begin{array}{c}-0.011 \\
(0.058)\end{array}$ & 0.263 \\
\hline 14 years after birth & $\begin{array}{c}0.025 \\
(0.052)\end{array}$ & $\begin{array}{c}0.101 \\
(0.101)\end{array}$ & $\begin{array}{c}0.004 \\
(0.060)\end{array}$ & 0.406 \\
\hline 15 years after birth & $\begin{array}{c}0.019 \\
(0.053)\end{array}$ & $\begin{array}{c}0.097 \\
(0.103)\end{array}$ & $\begin{array}{r}-0.003 \\
(0.061)\end{array}$ & 0.404 \\
\hline 16 years after birth & $\begin{array}{c}0.015 \\
(0.054)\end{array}$ & $\begin{array}{c}0.081 \\
(0.107)\end{array}$ & $\begin{array}{r}-0.002 \\
(0.062)\end{array}$ & 0.504 \\
\hline 17 years after birth & $\begin{array}{c}0.004 \\
(0.053)\end{array}$ & $\begin{array}{c}0.065 \\
(0.103)\end{array}$ & $\begin{array}{r}-0.010 \\
(0.062)\end{array}$ & 0.535 \\
\hline
\end{tabular}

Notes: Each row represents two separate regressions. Estimation results by availability of nursery are based on fully interacted models. Coefficients based on 2SLS estimations, with years on parental leave instrumented by the assignment to the reform. We use local linear regressions including triangular weights and separate linear trends on each side of the discontinuity. We use a bandwidth of 30 days, exclude children born \pm 5 days around the cutoff date, and control for the child's sex, low maternal SES, maternal age groups, whether the mother was born abroad, and whether the child was a pre-term birth. Standard errors (shown in parentheses) are clustered at the community level. $*, * *$ and $* * *$ indicate statistical significance at the 10 -percent, 5-percent and 1-percent level. ${ }^{a}$ Prob $>$ chi2 of difference in coefficients between communities with and w/o nursery. ${ }^{b}$ The number of children are measured at the first child's birthday in each year. 
Table A.13: Maternal employment

\begin{tabular}{|c|c|c|c|c|}
\hline & $\begin{array}{c}\text { All } \\
\text { communities }\end{array}$ & $\begin{array}{l}\text { Communities } \\
\text { with nursery }\end{array}$ & $\begin{array}{l}\text { Communities } \\
\text { w/o nursery }\end{array}$ & $\begin{array}{c}\text { P-value } \\
\Delta^{a}\end{array}$ \\
\hline \multicolumn{5}{|c|}{ Mother is employed ${ }^{b}$} \\
\hline 1 year after birth & $\begin{array}{c}0.005 \\
(0.010)\end{array}$ & $\begin{array}{c}-0.012 \\
(0.016)\end{array}$ & $\begin{array}{c}0.012 \\
(0.012)\end{array}$ & 0.230 \\
\hline 2 years after birth & $\begin{array}{c}-0.319^{* * *} \\
(0.025)\end{array}$ & $\begin{array}{c}-0.332^{* * *} \\
(0.043)\end{array}$ & $\begin{array}{c}-0.310^{* * *} \\
(0.031)\end{array}$ & 0.668 \\
\hline 3 years after birth & $\begin{array}{c}-0.050^{*} \\
(0.029)\end{array}$ & $\begin{array}{c}-0.103^{* *} \\
(0.050)\end{array}$ & $\begin{array}{c}-0.026 \\
(0.035)\end{array}$ & 0.207 \\
\hline 4 years after birth & $\begin{array}{c}-0.011 \\
(0.029)\end{array}$ & $\begin{array}{c}-0.107^{*} \\
(0.055)\end{array}$ & $\begin{array}{c}0.026 \\
(0.035)\end{array}$ & 0.041 \\
\hline 5 years after birth & $\begin{array}{c}-0.013 \\
(0.030)\end{array}$ & $\begin{array}{c}-0.048 \\
(0.062)\end{array}$ & $\begin{array}{c}-0.005 \\
(0.034)\end{array}$ & 0.545 \\
\hline 6 years after birth & $\begin{array}{c}0.023 \\
(0.031)\end{array}$ & $\begin{array}{c}0.086 \\
(0.057)\end{array}$ & $\begin{array}{c}-0.002 \\
(0.037)\end{array}$ & 0.199 \\
\hline 7 years after birth & $\begin{array}{c}0.002 \\
(0.030)\end{array}$ & $\begin{array}{c}0.024 \\
(0.050)\end{array}$ & $\begin{array}{c}-0.008 \\
(0.038)\end{array}$ & 0.609 \\
\hline 8 years after birth & $\begin{array}{c}-0.016 \\
(0.032)\end{array}$ & $\begin{array}{c}-0.021 \\
(0.060)\end{array}$ & $\begin{array}{c}-0.019 \\
(0.038)\end{array}$ & 0.985 \\
\hline 9 years after birth & $\begin{array}{c}0.002 \\
(0.032)\end{array}$ & $\begin{array}{c}-0.016 \\
(0.061)\end{array}$ & $\begin{array}{c}0.006 \\
(0.037)\end{array}$ & 0.767 \\
\hline 10 years after birth & $\begin{array}{c}0.001 \\
(0.030)\end{array}$ & $\begin{array}{l}-0.005 \\
(0.054)\end{array}$ & $\begin{array}{c}0.000 \\
(0.036)\end{array}$ & 0.942 \\
\hline 11 years after birth & $\begin{array}{c}0.021 \\
(0.029)\end{array}$ & $\begin{array}{c}-0.027 \\
(0.049)\end{array}$ & $\begin{array}{c}0.035 \\
(0.036)\end{array}$ & 0.304 \\
\hline 12 years after birth & $\begin{array}{c}0.007 \\
(0.029)\end{array}$ & $\begin{array}{c}-0.031 \\
(0.047)\end{array}$ & $\begin{array}{c}0.017 \\
(0.036)\end{array}$ & 0.409 \\
\hline 13 years after birth & $\begin{array}{c}-0.010 \\
(0.027)\end{array}$ & $\begin{array}{l}-0.060 \\
(0.043)\end{array}$ & $\begin{array}{c}0.004 \\
(0.034)\end{array}$ & 0.238 \\
\hline 14 years after birth & $\begin{array}{c}0.020 \\
(0.027)\end{array}$ & $\begin{array}{c}-0.017 \\
(0.043)\end{array}$ & $\begin{array}{c}0.027 \\
(0.033)\end{array}$ & 0.420 \\
\hline 15 years after birth & $\begin{array}{c}-0.002 \\
(0.027)\end{array}$ & $\begin{array}{c}0.007 \\
(0.050)\end{array}$ & $\begin{array}{r}-0.012 \\
(0.033)\end{array}$ & 0.752 \\
\hline 16 years after birth & $\begin{array}{c}0.013 \\
(0.027)\end{array}$ & $\begin{array}{c}0.025 \\
(0.046)\end{array}$ & $\begin{array}{c}0.004 \\
(0.033)\end{array}$ & 0.712 \\
\hline 17 years after birth & $\begin{array}{c}0.022 \\
(0.025)\end{array}$ & $\begin{array}{r}-0.000 \\
(0.042)\end{array}$ & $\begin{array}{c}0.028 \\
(0.031)\end{array}$ & 0.586 \\
\hline
\end{tabular}

Notes: Each row represents two separate regressions. Estimation results by availability of nursery are based on fully interacted models. Coefficients based on 2SLS estimations, with years on parental leave instrumented by the assignment to the reform. We use local linear regressions including triangular weights and separate linear trends on each side of the discontinuity. We use a bandwidth of 30 days, exclude children born \pm 5 days around the cutoff date, and control for the child's sex, low maternal SES, maternal age groups, whether the mother was born abroad, and whether the child was a pre-term birth. Standard errors (shown in parentheses) are clustered at the community level. $*, * *$ and $* * *$ indicate statistical significance at the 10-percent, 5-percent and 1-percent level. ${ }^{a}$ Prob $>$ chi2 of difference in coefficients between communities with and w/o nursery. ${ }^{b}$ Maternal employment is measured in January following the child's birthday in each year. 
Table A.14: Maternal full-time employment

\begin{tabular}{|c|c|c|c|c|}
\hline & $\begin{array}{c}\text { All } \\
\text { communities }\end{array}$ & $\begin{array}{l}\text { Communities } \\
\text { with nursery }\end{array}$ & $\begin{array}{l}\text { Communities } \\
\text { w/o nursery }\end{array}$ & $\begin{array}{r}\text { P-value } \\
\Delta^{a}\end{array}$ \\
\hline \multicolumn{5}{|c|}{ Mother works full-time ${ }^{b}$} \\
\hline 1 year after birth & $\begin{array}{c}-0.005 \\
(0.006)\end{array}$ & $\begin{array}{c}-0.015 \\
(0.012)\end{array}$ & $\begin{array}{c}-0.001 \\
(0.007)\end{array}$ & 0.307 \\
\hline 2 years after birth & $\begin{array}{c}-0.167^{* * *} \\
(0.021)\end{array}$ & $\begin{array}{c}-0.244^{* * *} \\
(0.038)\end{array}$ & $\begin{array}{c}-0.139 * * * \\
(0.025)\end{array}$ & 0.022 \\
\hline 3 years after birth & $\begin{array}{c}-0.003 \\
(0.024)\end{array}$ & $\begin{array}{c}-0.076^{*} \\
(0.045)\end{array}$ & $\begin{array}{c}0.026 \\
(0.028)\end{array}$ & 0.056 \\
\hline 4 years after birth & $\begin{array}{c}0.040 \\
(0.025)\end{array}$ & $\begin{array}{c}-0.046 \\
(0.046)\end{array}$ & $\begin{array}{l}0.074^{* *} \\
(0.029)\end{array}$ & 0.027 \\
\hline 5 years after birth & $\begin{array}{c}0.030 \\
(0.026)\end{array}$ & $\begin{array}{r}-0.057 \\
(0.046)\end{array}$ & $\begin{array}{l}0.060^{* *} \\
(0.030)\end{array}$ & 0.034 \\
\hline 6 years after birth & $\begin{array}{c}0.034 \\
(0.027)\end{array}$ & $\begin{array}{c}-0.008 \\
(0.046)\end{array}$ & $\begin{array}{c}0.046 \\
(0.032)\end{array}$ & 0.337 \\
\hline 7 years after birth & $\begin{array}{c}0.019 \\
(0.027)\end{array}$ & $\begin{array}{c}-0.065 \\
(0.047)\end{array}$ & $\begin{array}{c}0.047 \\
(0.032)\end{array}$ & 0.050 \\
\hline 8 years after birth & $\begin{array}{c}0.019 \\
(0.029)\end{array}$ & $\begin{array}{c}-0.105^{*} \\
(0.055)\end{array}$ & $\begin{array}{c}0.060^{*} \\
(0.033)\end{array}$ & 0.010 \\
\hline 9 years after birth & $\begin{array}{c}0.060^{*} \\
(0.032)\end{array}$ & $\begin{array}{c}-0.083 \\
(0.062)\end{array}$ & $\begin{array}{l}0.109 * * * \\
(0.034)\end{array}$ & 0.006 \\
\hline 10 years after birth & $\begin{array}{c}0.038 \\
(0.030)\end{array}$ & $\begin{array}{c}-0.082 \\
(0.055)\end{array}$ & $\begin{array}{l}0.076^{* *} \\
(0.035)\end{array}$ & 0.015 \\
\hline 11 years after birth & $\begin{array}{c}0.057^{*} \\
(0.031)\end{array}$ & $\begin{array}{c}-0.077 \\
(0.060)\end{array}$ & $\begin{array}{l}0.102^{* * *} \\
(0.035)\end{array}$ & 0.010 \\
\hline 12 years after birth & $\begin{array}{c}0.047 \\
(0.031)\end{array}$ & $\begin{array}{c}-0.091 \\
(0.058)\end{array}$ & $\begin{array}{l}0.094^{* * *} \\
(0.035)\end{array}$ & 0.007 \\
\hline 13 years after birth & $\begin{array}{c}0.029 \\
(0.030)\end{array}$ & $\begin{array}{c}-0.088 \\
(0.055)\end{array}$ & $\begin{array}{c}0.067^{*} \\
(0.035)\end{array}$ & 0.017 \\
\hline 14 years after birth & $\begin{array}{c}0.053^{*} \\
(0.030)\end{array}$ & $\begin{array}{c}-0.049 \\
(0.051)\end{array}$ & $\begin{array}{l}0.083^{* *} \\
(0.036)\end{array}$ & 0.033 \\
\hline 15 years after birth & $\begin{array}{c}0.038 \\
(0.030)\end{array}$ & $\begin{array}{c}-0.019 \\
(0.048)\end{array}$ & $\begin{array}{c}0.050 \\
(0.036)\end{array}$ & 0.247 \\
\hline 16 years after birth & $\begin{array}{c}0.029 \\
(0.029)\end{array}$ & $\begin{array}{r}-0.040 \\
(0.047)\end{array}$ & $\begin{array}{c}0.046 \\
(0.036)\end{array}$ & 0.148 \\
\hline 17 years after birth & $\begin{array}{c}0.030 \\
(0.030)\end{array}$ & $\begin{array}{r}-0.015 \\
(0.048)\end{array}$ & $\begin{array}{c}0.038 \\
(0.037)\end{array}$ & 0.385 \\
\hline
\end{tabular}

Notes: Each row represents two separate regressions. Estimation results by availability of nursery are based on fully interacted models. Coefficients based on 2SLS estimations, with years on parental leave instrumented by the assignment to the reform. We use local linear regressions including triangular weights and separate linear trends on each side of the discontinuity. We use a bandwidth of 30 days, exclude children born \pm 5 days around the cutoff date, and control for the child's sex, low maternal SES, maternal age groups, whether the mother was born abroad, and whether the child was a pre-term birth. Standard errors (shown in parentheses) are clustered at the community level. $*$, ** and $* * *$ indicate statistical significance at the 10-percent, 5-percent and 1-percent level. ${ }^{a}$ Prob $>$ chi2 of difference in coefficients between communities with and w/o nursery. ${ }^{b}$ The mother works and earns $\geq 75 \%$ of her pre-birth earnings in January following the child's birthday in each year. 
Table A.15: Family status — full sample

\begin{tabular}{|c|c|c|c|c|}
\hline & $\begin{array}{c}\text { All } \\
\text { communities }\end{array}$ & $\begin{array}{l}\text { Communities } \\
\text { with nursery }\end{array}$ & $\begin{array}{l}\text { Communities } \\
\text { w/o nursery }\end{array}$ & $\begin{array}{c}\mathrm{P} \text {-value } \\
\Delta^{a}\end{array}$ \\
\hline \multicolumn{5}{|c|}{ Currently married, full sample ${ }^{b}$} \\
\hline 1 year after birth & $\begin{array}{r}-0.046^{*} \\
(0.024)\end{array}$ & $\begin{array}{c}-0.046 \\
(0.044)\end{array}$ & $\begin{array}{c}-0.045 \\
(0.029)\end{array}$ & 0.974 \\
\hline 2 years after birth & $\begin{array}{c}-0.029 \\
(0.023)\end{array}$ & $\begin{array}{c}-0.012 \\
(0.043)\end{array}$ & $\begin{array}{c}-0.033 \\
(0.028)\end{array}$ & 0.683 \\
\hline 3 years after birth & $\begin{array}{c}-0.021 \\
(0.023)\end{array}$ & $\begin{array}{c}0.010 \\
(0.043)\end{array}$ & $\begin{array}{c}-0.032 \\
(0.027)\end{array}$ & 0.408 \\
\hline 4 years after birth & $\begin{array}{c}-0.026 \\
(0.022)\end{array}$ & $\begin{array}{c}-0.022 \\
(0.042)\end{array}$ & $\begin{array}{c}-0.025 \\
(0.026)\end{array}$ & 0.959 \\
\hline 5 years after birth & $\begin{array}{c}-0.029 \\
(0.022)\end{array}$ & $\begin{array}{c}-0.007 \\
(0.042)\end{array}$ & $\begin{array}{c}-0.035 \\
(0.026)\end{array}$ & 0.574 \\
\hline 6 years after birth & $\begin{array}{c}-0.020 \\
(0.022)\end{array}$ & $\begin{array}{c}-0.008 \\
(0.043)\end{array}$ & $\begin{array}{c}-0.022 \\
(0.026)\end{array}$ & 0.774 \\
\hline 7 years after birth & $\begin{array}{c}-0.005 \\
(0.022)\end{array}$ & $\begin{array}{c}0.014 \\
(0.043)\end{array}$ & $\begin{array}{c}-0.010 \\
(0.026)\end{array}$ & 0.625 \\
\hline 8 years after birth & $\begin{array}{c}-0.004 \\
(0.022)\end{array}$ & $\begin{array}{c}0.000 \\
(0.043)\end{array}$ & $\begin{array}{c}-0.003 \\
(0.026)\end{array}$ & 0.950 \\
\hline 9 years after birth & $\begin{array}{c}-0.010 \\
(0.022)\end{array}$ & $\begin{array}{c}-0.001 \\
(0.043)\end{array}$ & $\begin{array}{c}-0.011 \\
(0.026)\end{array}$ & 0.848 \\
\hline 10 years after birth & $\begin{array}{c}-0.007 \\
(0.022)\end{array}$ & $\begin{array}{c}-0.003 \\
(0.044)\end{array}$ & $\begin{array}{c}-0.006 \\
(0.026)\end{array}$ & 0.950 \\
\hline 11 years after birth & $\begin{array}{c}-0.010 \\
(0.023)\end{array}$ & $\begin{array}{c}-0.027 \\
(0.044)\end{array}$ & $\begin{array}{c}-0.000 \\
(0.026)\end{array}$ & 0.598 \\
\hline 12 years after birth & $\begin{array}{c}-0.003 \\
(0.023)\end{array}$ & $\begin{array}{c}-0.016 \\
(0.044)\end{array}$ & $\begin{array}{c}0.005 \\
(0.026)\end{array}$ & 0.687 \\
\hline 13 years after birth & $\begin{array}{c}-0.007 \\
(0.023)\end{array}$ & $\begin{array}{c}-0.021 \\
(0.045)\end{array}$ & $\begin{array}{c}0.001 \\
(0.027)\end{array}$ & 0.671 \\
\hline 14 years after birth & $\begin{array}{c}-0.011 \\
(0.023)\end{array}$ & $\begin{array}{c}-0.023 \\
(0.045)\end{array}$ & $\begin{array}{c}-0.003 \\
(0.027)\end{array}$ & 0.699 \\
\hline 15 years after birth & $\begin{array}{c}-0.012 \\
(0.023)\end{array}$ & $\begin{array}{c}-0.040 \\
(0.045)\end{array}$ & $\begin{array}{c}0.002 \\
(0.027)\end{array}$ & 0.435 \\
\hline 16 years after birth & $\begin{array}{c}-0.008 \\
(0.024)\end{array}$ & $\begin{array}{c}-0.029 \\
(0.046)\end{array}$ & $\begin{array}{c}0.005 \\
(0.027)\end{array}$ & 0.522 \\
\hline 17 years after birth & $\begin{array}{c}-0.010 \\
(0.024)\end{array}$ & $\begin{array}{c}-0.032 \\
(0.046)\end{array}$ & $\begin{array}{c}0.003 \\
(0.027)\end{array}$ & 0.515 \\
\hline
\end{tabular}

Notes: Each row represents two separate regressions. Estimation results by availability of nursery are based on fully interacted models. Coefficients based on 2SLS estimations, with years on parental leave instrumented by the assignment to the reform. We use local linear regressions including triangular weights and separate linear trends on each side of the discontinuity. We use a bandwidth of 30 days, exclude children born \pm 5 days around the cutoff date, and control for the child's sex, low maternal SES, maternal age groups, whether the mother was born abroad, and whether the child was a pre-term birth. Standard errors (shown in parentheses) are clustered at the community level. *, ** and ${ }^{* * *}$ indicate statistical significance at the 10-percent, 5-percent and 1-percent level. ${ }^{a}$ Prob $>$ chi2 of difference in coefficients between communities with and w/o nursery. ${ }^{b}$ The mother is currently married. 
Table A.16: Family status - cond. on being married at birth

\begin{tabular}{|c|c|c|c|c|}
\hline & $\begin{array}{c}\text { All } \\
\text { communities }\end{array}$ & $\begin{array}{l}\text { Communities } \\
\text { with nursery }\end{array}$ & $\begin{array}{l}\text { Communities } \\
\text { w/o nursery }\end{array}$ & $\mathrm{P}$-value $\Delta^{a}$ \\
\hline \multicolumn{5}{|c|}{ Currently married, cond. on being married at birth ${ }^{b}$} \\
\hline 1 year after birth & $\begin{array}{r}-0.000 \\
(0.003)\end{array}$ & $\begin{array}{c}-0.006 \\
(0.007)\end{array}$ & $\begin{array}{c}0.003 \\
(0.003)\end{array}$ & 0.235 \\
\hline 2 years after birth & $\begin{array}{c}0.000 \\
(0.005)\end{array}$ & $\begin{array}{c}-0.013 \\
(0.011)\end{array}$ & $\begin{array}{c}0.007 \\
(0.005)\end{array}$ & 0.090 \\
\hline 3 years after birth & $\begin{array}{c}-0.001 \\
(0.007)\end{array}$ & $\begin{array}{c}0.000 \\
(0.016)\end{array}$ & $\begin{array}{c}-0.003 \\
(0.007)\end{array}$ & 0.862 \\
\hline 4 years after birth & $\begin{array}{c}-0.007 \\
(0.009)\end{array}$ & $\begin{array}{c}-0.015 \\
(0.020)\end{array}$ & $\begin{array}{c}-0.003 \\
(0.009)\end{array}$ & 0.582 \\
\hline 5 years after birth & $\begin{array}{c}-0.002 \\
(0.010)\end{array}$ & $\begin{array}{c}0.003 \\
(0.025)\end{array}$ & $\begin{array}{c}-0.004 \\
(0.010)\end{array}$ & 0.781 \\
\hline 6 years after birth & $\begin{array}{c}0.001 \\
(0.012)\end{array}$ & $\begin{array}{c}0.006 \\
(0.028)\end{array}$ & $\begin{array}{c}0.000 \\
(0.013)\end{array}$ & 0.852 \\
\hline 7 years after birth & $\begin{array}{l}0.016 \\
(0.014)\end{array}$ & $\begin{array}{c}0.020 \\
(0.030)\end{array}$ & $\begin{array}{c}0.017 \\
(0.015)\end{array}$ & 0.929 \\
\hline 8 years after birth & $\begin{array}{c}0.018 \\
(0.015)\end{array}$ & $\begin{array}{c}0.013 \\
(0.032)\end{array}$ & $\begin{array}{c}0.022 \\
(0.017)\end{array}$ & 0.819 \\
\hline 9 years after birth & $\begin{array}{c}0.019 \\
(0.017)\end{array}$ & $\begin{array}{l}0.020 \\
(0.035)\end{array}$ & $\begin{array}{c}0.020 \\
(0.018)\end{array}$ & 0.997 \\
\hline 10 years after birth & $\begin{array}{c}0.026 \\
(0.018)\end{array}$ & $\begin{array}{c}0.031 \\
(0.037)\end{array}$ & $\begin{array}{c}0.026 \\
(0.019)\end{array}$ & 0.900 \\
\hline 11 years after birth & $\begin{array}{c}0.019 \\
(0.019)\end{array}$ & $\begin{array}{c}0.004 \\
(0.039)\end{array}$ & $\begin{array}{c}0.028 \\
(0.020)\end{array}$ & 0.586 \\
\hline 12 years after birth & $\begin{array}{c}0.021 \\
(0.020)\end{array}$ & $\begin{array}{c}0.014 \\
(0.042)\end{array}$ & $\begin{array}{c}0.025 \\
(0.021)\end{array}$ & 0.812 \\
\hline 13 years after birth & $\begin{array}{c}0.014 \\
(0.020)\end{array}$ & $\begin{array}{c}0.021 \\
(0.043)\end{array}$ & $\begin{array}{c}0.012 \\
(0.022)\end{array}$ & 0.848 \\
\hline 14 years after birth & $\begin{array}{c}0.012 \\
(0.021)\end{array}$ & $\begin{array}{c}0.021 \\
(0.045)\end{array}$ & $\begin{array}{c}0.009 \\
(0.023)\end{array}$ & 0.800 \\
\hline 15 years after birth & $\begin{array}{c}0.004 \\
(0.022)\end{array}$ & $\begin{array}{c}-0.003 \\
(0.047)\end{array}$ & $\begin{array}{c}0.008 \\
(0.024)\end{array}$ & 0.830 \\
\hline 16 years after birth & $\begin{array}{c}0.006 \\
(0.023)\end{array}$ & $\begin{array}{c}0.004 \\
(0.048)\end{array}$ & $\begin{array}{c}0.008 \\
(0.025)\end{array}$ & 0.935 \\
\hline 17 years after birth & $\begin{array}{c}0.005 \\
(0.024)\end{array}$ & $\begin{array}{c}-0.011 \\
(0.049)\end{array}$ & $\begin{array}{c}0.015 \\
(0.026)\end{array}$ & 0.641 \\
\hline
\end{tabular}

Notes: Each row represents two separate regressions. Estimation results by availability of nursery are based on fully interacted models. Coefficients based on 2SLS estimations, with years on parental leave instrumented by the assignment to the reform. We use local linear regressions including triangular weights and separate linear trends on each side of the discontinuity. We use a bandwidth of 30 days, exclude children born \pm 5 days around the cutoff date, and control for the child's sex, low maternal SES, maternal age groups, whether the mother was born abroad, and whether the child was a pre-term birth. Standard errors (shown in parentheses) are clustered at the community level. *, ** and ${ }^{* * *}$ indicate statistical significance at the 10-percent, 5-percent and 1-percent level. ${ }^{a}$ Prob $>$ chi2 of difference in coefficients between communities with and w/o nursery. ${ }^{b}$ Currently married in the sample of mothers who have been married at birth. 
Table A.17: Family status — cond. on not being married at birth

\begin{tabular}{|c|c|c|c|c|}
\hline & $\begin{array}{c}\text { All } \\
\text { communities }\end{array}$ & $\begin{array}{l}\text { Communities } \\
\text { with nursery }\end{array}$ & $\begin{array}{l}\text { Communities } \\
\text { w/o nursery }\end{array}$ & $\mathrm{P}$-value $\Delta^{a}$ \\
\hline \multicolumn{5}{|c|}{ Currently married, cond. on not being married at birth ${ }^{b}$} \\
\hline 1 year after birth & $\begin{array}{c}-0.009 \\
(0.023)\end{array}$ & $\begin{array}{c}0.018 \\
(0.034)\end{array}$ & $\begin{array}{r}-0.013 \\
(0.029)\end{array}$ & 0.496 \\
\hline 2 years after birth & $\begin{array}{c}0.024 \\
(0.031)\end{array}$ & $\begin{array}{l}0.126^{* *} \\
(0.049)\end{array}$ & $\begin{array}{c}-0.003 \\
(0.038)\end{array}$ & 0.038 \\
\hline 3 years after birth & $\begin{array}{c}0.038 \\
(0.035)\end{array}$ & $\begin{array}{l}0.159^{* * *} \\
(0.057)\end{array}$ & $\begin{array}{c}0.003 \\
(0.042)\end{array}$ & 0.029 \\
\hline 4 years after birth & $\begin{array}{c}0.024 \\
(0.038)\end{array}$ & $\begin{array}{c}0.084 \\
(0.065)\end{array}$ & $\begin{array}{c}0.011 \\
(0.045)\end{array}$ & 0.353 \\
\hline 5 years after birth & $\begin{array}{c}0.004 \\
(0.038)\end{array}$ & $\begin{array}{c}0.087 \\
(0.067)\end{array}$ & $\begin{array}{r}-0.017 \\
(0.045)\end{array}$ & 0.195 \\
\hline 6 years after birth & $\begin{array}{c}0.017 \\
(0.039)\end{array}$ & $\begin{array}{c}0.076 \\
(0.069)\end{array}$ & $\begin{array}{c}0.004 \\
(0.046)\end{array}$ & 0.383 \\
\hline 7 years after birth & $\begin{array}{c}0.029 \\
(0.039)\end{array}$ & $\begin{array}{c}0.112 \\
(0.070)\end{array}$ & $\begin{array}{c}0.008 \\
(0.046)\end{array}$ & 0.216 \\
\hline 8 years after birth & $\begin{array}{c}0.028 \\
(0.039)\end{array}$ & $\begin{array}{c}0.077 \\
(0.071)\end{array}$ & $\begin{array}{c}0.017 \\
(0.046)\end{array}$ & 0.478 \\
\hline 9 years after birth & $\begin{array}{c}0.010 \\
(0.039)\end{array}$ & $\begin{array}{c}0.059 \\
(0.072)\end{array}$ & $\begin{array}{c}-0.001 \\
(0.046)\end{array}$ & 0.476 \\
\hline 10 years after birth & $\begin{array}{c}0.005 \\
(0.040)\end{array}$ & $\begin{array}{c}0.031 \\
(0.072)\end{array}$ & $\begin{array}{c}0.002 \\
(0.046)\end{array}$ & 0.728 \\
\hline 11 years after birth & $\begin{array}{c}0.005 \\
(0.040)\end{array}$ & $\begin{array}{c}0.012 \\
(0.072)\end{array}$ & $\begin{array}{c}0.009 \\
(0.046)\end{array}$ & 0.974 \\
\hline 12 years after birth & $\begin{array}{c}0.019 \\
(0.040)\end{array}$ & $\begin{array}{c}0.023 \\
(0.071)\end{array}$ & $\begin{array}{c}0.023 \\
(0.046)\end{array}$ & 1.000 \\
\hline 13 years after birth & $\begin{array}{c}0.019 \\
(0.040)\end{array}$ & $\begin{array}{r}-0.006 \\
(0.071)\end{array}$ & $\begin{array}{c}0.032 \\
(0.046)\end{array}$ & 0.653 \\
\hline 14 years after birth & $\begin{array}{c}0.011 \\
(0.040)\end{array}$ & $\begin{array}{r}-0.017 \\
(0.071)\end{array}$ & $\begin{array}{c}0.026 \\
(0.046)\end{array}$ & 0.611 \\
\hline 15 years after birth & $\begin{array}{c}0.018 \\
(0.040)\end{array}$ & $\begin{array}{r}-0.021 \\
(0.071)\end{array}$ & $\begin{array}{c}0.036 \\
(0.046)\end{array}$ & 0.497 \\
\hline 16 years after birth & $\begin{array}{c}0.027 \\
(0.040)\end{array}$ & $\begin{array}{r}-0.005 \\
(0.071)\end{array}$ & $\begin{array}{c}0.043 \\
(0.046)\end{array}$ & 0.573 \\
\hline 17 years after birth & $\begin{array}{c}0.021 \\
(0.039)\end{array}$ & $\begin{array}{c}0.020 \\
(0.071)\end{array}$ & $\begin{array}{c}0.028 \\
(0.046)\end{array}$ & 0.923 \\
\hline
\end{tabular}

Notes: Each row represents two separate regressions. Estimation results by availability of nursery are based on fully interacted models. Coefficients based on 2SLS estimations, with years on parental leave instrumented by the assignment to the reform. We use local linear regressions including triangular weights and separate linear trends on each side of the discontinuity. We use a bandwidth of 30 days, exclude children born \pm 5 days around the cutoff date, and control for the child's sex, low maternal SES, maternal age groups, whether the mother was born abroad, and whether the child was a pre-term birth. Standard errors (shown in parentheses) are clustered at the community level. *, ** and *** indicate statistical significance at the 10-percent, 5-percent and 1-percent level. ${ }^{a}$ Prob $>$ chi 2 of difference in coefficients between communities with and w/o nursery. ${ }^{b}$ Currently married in the sample of mothers who have not been married at birth. 
Table A.18: Sensitivity: Child outcomes by availability of nursery \& maternal work propensity - cond. on family size and maternal (full-time) employment

\begin{tabular}{|c|c|c|c|c|c|c|}
\hline & \multicolumn{3}{|c|}{ Low work propensity ${ }^{a}$} & \multicolumn{3}{|c|}{ High work propensity ${ }^{a}$} \\
\hline & $\begin{array}{l}\text { Communities } \\
\text { with nursery }\end{array}$ & $\begin{array}{l}\text { Communities } \\
\text { w/o nursery }\end{array}$ & $\begin{array}{c}\mathrm{P} \text {-value } \\
\Delta^{b}\end{array}$ & $\begin{array}{l}\text { Communities } \\
\text { with nursery }\end{array}$ & $\begin{array}{l}\text { Communities } \\
\text { w/o nursery }\end{array}$ & $\begin{array}{c}\text { P-value } \\
\Delta^{b}\end{array}$ \\
\hline \multicolumn{7}{|c|}{ Number of children \& maternal emp. ${ }^{c}$} \\
\hline Active (age 17) & $\begin{array}{c}0.030 \\
(0.030)\end{array}$ & $\begin{array}{c}0.008 \\
(0.010)\end{array}$ & 0.488 & $\begin{array}{c}0.011 \\
(0.036)\end{array}$ & $\begin{array}{l}0.027^{* *} \\
(0.013)\end{array}$ & 0.667 \\
\hline Active (age 23) & $\begin{array}{c}0.026 \\
(0.057)\end{array}$ & $\begin{array}{r}-0.014 \\
(0.028)\end{array}$ & 0.529 & $\begin{array}{r}-0.064 \\
(0.055)\end{array}$ & $\begin{array}{l}0.077^{* * *} \\
(0.030)\end{array}$ & 0.025 \\
\hline Active (age 17-23) & $\begin{array}{c}0.012 \\
(0.035)\end{array}$ & $\begin{array}{c}0.013 \\
(0.017)\end{array}$ & 0.979 & $\begin{array}{c}0.027 \\
(0.047)\end{array}$ & $\begin{array}{l}0.048^{* *} \\
(0.019)\end{array}$ & 0.687 \\
\hline Non-disabled & $\begin{array}{c}0.021 \\
(0.050)\end{array}$ & $\begin{array}{c}0.032 \\
(0.020)\end{array}$ & 0.829 & $\begin{array}{r}-0.019 \\
(0.030)\end{array}$ & $\begin{array}{c}0.049^{*} \\
(0.025)\end{array}$ & 0.086 \\
\hline Fit for military (boys) & $\begin{array}{c}0.115 \\
(0.109)\end{array}$ & $\begin{array}{c}0.076 \\
(0.053)\end{array}$ & 0.745 & $\begin{array}{r}-0.044 \\
(0.081)\end{array}$ & $\begin{array}{l}0.191^{* * *} \\
(0.060)\end{array}$ & 0.019 \\
\hline \multicolumn{7}{|c|}{ Number of children $\&$ maternal full-time emp. ${ }^{d}$} \\
\hline Active (age 17) & $\begin{array}{c}0.028 \\
(0.033)\end{array}$ & $\begin{array}{c}0.012 \\
(0.011)\end{array}$ & 0.648 & $\begin{array}{c}-0.007 \\
(0.034)\end{array}$ & $\begin{array}{l}0.029^{* *} \\
(0.014)\end{array}$ & 0.318 \\
\hline Active (age 23) & $\begin{array}{c}0.025 \\
(0.060)\end{array}$ & $\begin{array}{c}-0.011 \\
(0.030)\end{array}$ & 0.593 & $\begin{array}{r}-0.035 \\
(0.053)\end{array}$ & $\begin{array}{l}0.087^{* * * *} \\
(0.031)\end{array}$ & 0.048 \\
\hline Active (age 17-23) & $\begin{array}{c}0.011 \\
(0.036)\end{array}$ & $\begin{array}{c}0.007 \\
(0.018)\end{array}$ & 0.937 & $\begin{array}{c}0.027 \\
(0.050)\end{array}$ & $\begin{array}{l}0.062^{* * * *} \\
(0.020)\end{array}$ & 0.507 \\
\hline Non-disabled & $\begin{array}{c}0.010 \\
(0.049)\end{array}$ & $\begin{array}{c}0.041^{*} \\
(0.021)\end{array}$ & 0.568 & $\begin{array}{r}-0.034 \\
(0.035)\end{array}$ & $\begin{array}{c}0.044^{*} \\
(0.026)\end{array}$ & 0.072 \\
\hline Fit for military (boys) & $\begin{array}{c}0.061 \\
(0.104)\end{array}$ & $\begin{array}{c}0.096^{*} \\
(0.055)\end{array}$ & 0.765 & $\begin{array}{r}-0.048 \\
(0.077)\end{array}$ & $\begin{array}{l}0.223^{* * *} \\
(0.063)\end{array}$ & 0.006 \\
\hline
\end{tabular}

Notes: Estimation results are based on fully interacted models, estimated separately for mothers with low and high work propensity. Coefficients are based on 2SLS estimations, with years on parental leave instrumented by the assignment to the reform. We use local linear regressions including triangular weights and separate trends before and after the cutoff. We use a bandwidth of 30 days, exclude children born \pm 5 days around the cutoff date, and control for the child's sex, low maternal SES, maternal age groups, whether the mother was born abroad, and whether the child was a pre-term birth. Standard errors (shown in parentheses) are clustered at the community level. * ${ }^{* *}$ and $* * *$ indicate statistical significance at the $10-$ percent, 5-percent and 1-percent level. ${ }^{a}$ Maternal characteristics indicate a low/high propensity of being employed $>0$ days in second year after childbirth, low/high according to median prediction $(0.51)$. ${ }^{b}$ Prob $>\mathrm{F}(\mathrm{chi} 2)$ of difference in coefficients between mothers living in communities with and without nursery based on fully interacted regressions. ${ }^{c}$ Additional control variables: number of children and binary indicators for maternal employment 3, 5 , and 10 years after birth. ${ }^{d}$ Additional control variables: number of children and binary indicators for maternal full-time employment 3,5 , and 10 years after birth. 
Table A.19: Total length of paid maternity, parental and home care leave available to mothers (2018)

\begin{tabular}{|c|c|c|c|}
\hline Country & $\begin{array}{l}\text { Weeks } \\
\text { paid } \\
\text { child- } \\
\text { related } \\
\text { leave }\end{array}$ & $\begin{array}{l}\text { Weeks of } \\
\text { paid leave } \\
\text { (incl. } \\
\text { long- } \\
\text { option) }\end{array}$ & $\begin{array}{l}\text { Maximum } \\
\text { weeks of job- } \\
\text { protected } \\
\text { leave, regard- } \\
\text { less of income } \\
\text { support }\end{array}$ \\
\hline Australia & 18 & 18 & 52 \\
\hline Austria & 60 & 138 & 103.3 \\
\hline Belgium & 32.3 & 32.3 & 32.3 \\
\hline Canada & 51 & 77 & 77 \\
\hline Czech Republic & 63.3 & 214 & 162 \\
\hline Denmark & 50 & 64 & 50 \\
\hline Finland & 161 & 161 & 161 \\
\hline France & 42 & 42 & 162 \\
\hline Germany & 58 & 110 & 162 \\
\hline Greece & 43 & 43 & 60.3 \\
\hline Hungary & 160 & 160 & 160 \\
\hline Iceland & 26 & 26 & 43.3 \\
\hline Ireland & 26 & 26 & 60 \\
\hline Italy & 47.7 & 47.7 & 47.7 \\
\hline Japan & 58 & 58 & 58 \\
\hline Korea & 64.9 & 64.9 & 64.9 \\
\hline Luxembourg & 37.3 & 37.3 & 37.3 \\
\hline Mexico & 12 & 12 & 12 \\
\hline Netherlands & 16 & 16 & 42 \\
\hline New Zealand & 18 & 18 & 58 \\
\hline Norway & 91 & 101 & 91 \\
\hline Poland & 52 & 52 & 203.7 \\
\hline Portugal & 30.1 & 34.4 & 134.1 \\
\hline Slovak Republic & 164 & 164 & 164 \\
\hline Spain & 16 & 16 & 166 \\
\hline Sweden & 55.7 & 55.7 & 85 \\
\hline Switzerland & 14 & 14 & 16 \\
\hline Turkey & 16 & 16 & 42 \\
\hline United Kingdom & 39 & 39 & 70 \\
\hline United States & 0 & 0 & 12 \\
\hline Average & 50.7 & 61.9 & 86.3 \\
\hline
\end{tabular}

Notes: Data from the OECD Family Database (PF2 5: Trends in leave entitlements around childbirth, updated November 2019). Note that the expression paid child-related leave is an umbrella term for policies granting parents the right to paid child-related leave, which includes maternity leave, parental leave, and other forms of childrelated leave, e.g., cash-for-care transfers or home-care subsidies. Information refers to weeks of paid maternity leave and any weeks of paid parental leave and paid home care leave (sometimes under a different name, for example, childcare leave or child raising leave) that are available to mothers. Data reflect entitlements at the national or federal level only (no regional-specific entitlements). Several countries allow spreading leave benefits over a longer period ('long-option'). 
Table A.20: Employment rates of mothers (not absent on leave) of children aged 0 to 2 and formal and informal childcare enrolment of 0-2-year-olds (in 2014)

\begin{tabular}{|c|c|c|c|c|c|c|}
\hline Country & $\begin{array}{l}1 . \text { Ma- } \\
\text { ternal } \\
\text { employ- } \\
\text { ment rate } \\
\text { (MER), } \\
\text { not ab- } \\
\text { sent on } \\
\text { leave }\end{array}$ & $\begin{array}{l}2 . \quad \text { En- } \\
\text { rolment } \\
\text { rates in } \\
\text { early } \\
\text { childhood } \\
\text { education } \\
\text { and care } \\
\text { services } \\
\text { (ER- } \\
\text { ECE) }\end{array}$ & $\begin{array}{l}\text { 3. Dif- } \\
\text { ference } \\
\text { MER and } \\
\text { ER-ECE } \\
\text { (p.p.) }\end{array}$ & $\begin{array}{l}\text { 4. Dif- } \\
\text { ference } \\
\text { MER and } \\
\text { ER-ECE } \\
\text { (in \% of } \\
\text { MER) }\end{array}$ & $\begin{array}{l}\text { Chil- } \\
\text { dren in } \\
\text { infor- } \\
\text { mal care } \\
\text { during a } \\
\text { typical } \\
\text { week (in } \\
\%), 2017\end{array}$ & $\begin{array}{l}6 . \quad \text { Avg. } \\
\text { hours of } \\
\text { informal } \\
\text { childcare } \\
\text { per week, } \\
2017\end{array}$ \\
\hline Romania & 36.4 & 2.6 & 33.8 & 92.9 & 49.3 & \\
\hline Poland & 40.3 & 5.5 & 34.8 & 86.4 & 41.3 & 18.6 \\
\hline Greece & 47.6 & 12.8 & 34.8 & 73.1 & 49.9 & 24.4 \\
\hline Croatia & 45.5 & 17.1 & 28.4 & 62.4 & 32.8 & 23.1 \\
\hline Malta & 47.3 & 18.2 & 29.1 & 61.5 & 27.0 & 16.3 \\
\hline Czech Republic & 11.2 & 4.4 & 6.8 & 60.7 & 38.3 & 7.0 \\
\hline Bulgaria & 27.4 & 11.2 & 16.2 & 59.1 & 10.6 & 23.2 \\
\hline Cyprus & 61.2 & 25.5 & 35.7 & 58.3 & 44.4 & 27.6 \\
\hline Italy & 44.9 & 22.9 & 22.0 & 49.0 & 32.9 & 19.2 \\
\hline Austria & 31.2 & 16 & 15.2 & 48.7 & 31.7 & 8.2 \\
\hline Ireland & 48.2 & 27.4 & 20.8 & 43.1 & 25.2 & 17.4 \\
\hline Latvia & 34.5 & 21.6 & 12.9 & 37.3 & 10.3 & \\
\hline United Kingdom & 44.8 & 28.9 & 15.9 & 35.5 & 34.9 & 12.2 \\
\hline Spain & 54.3 & 36.9 & 17.4 & 32.0 & 12.0 & 26.3 \\
\hline Netherlands & 65.2 & 44.6 & 20.6 & 31.6 & 56.6 & 10.8 \\
\hline Portugal & 64.2 & 45 & 19.2 & 29.9 & 35.4 & 27.9 \\
\hline Slovenia & 50.5 & 37.4 & 13.1 & 26.0 & 48.4 & 11.6 \\
\hline Slovak Republic & 8.6 & 6.5 & 2.1 & 24.5 & 25.5 & 10.4 \\
\hline France & 51.5 & 39.5 & 12.0 & 23.3 & 19.0 & 16.2 \\
\hline Germany & 34.5 & 27.5 & 7.0 & 20.4 & & \\
\hline Belgium & 60.4 & 48.8 & 11.6 & 19.2 & 18.5 & 18.7 \\
\hline Luxembourg & 58.2 & 49 & 9.2 & 15.8 & 26.3 & 11.2 \\
\hline Finland & 38.2 & 33.2 & 5.0 & 13.1 & 1.4 & \\
\hline Estonia & 21.6 & 19.4 & 2.2 & 10.0 & 28.5 & 8.3 \\
\hline Lithuania & 24.0 & 22.9 & 1.1 & 4.5 & 23.1 & 19.0 \\
\hline Denmark & 68.0 & 69.6 & -1.6 & -2.3 & 1.1 & \\
\hline Hungary & 12.8 & 14.4 & -1.6 & -12.9 & 34.0 & 10.1 \\
\hline Average (unweighted) & 41.9 & 26.3 & 15.7 & 37.1 & 29.2 & 16.7 \\
\hline \multicolumn{7}{|c|}{$\begin{array}{l}\text { Notes: Employment rates for women with children aged 0-2, by maternity/parental leave status, } 2014 \text { or latest available } \\
\text { year (OECD Family Database, Chart LMF1.2.G.) Children aged 0-2 in formal childcare or education and duration in } \% \\
\text { over the population of age group (EU STAT / EU-SILC). 'Informal' childcare refers to unpaid care, usually provided by a } \\
\text { grandparent of the child or by other relatives, friends or neighbours. It excludes any care that is paid for regardless of who } \\
\text { is providing the paid-for care (OECD Family Database, Chart PF3.3.A.). Average hours of informal childcare per week } \\
\text { among those using at least one hour of informal childcare during a typical week, } 2017 \text { (OECD Family Database, Chart } \\
\text { PF3.3.D.) }\end{array}$} \\
\hline
\end{tabular}

